Western University

Scholarship@Western

Chemistry Publications

Chemistry Department

Fall 9-23-2015

Evaluation of Anisole-Substituted Boron Difluoride Formazanate Complexes for Fluorescence Cell Imaging

Ryan R. Maar

Stephanie M. Barbon

Neha Sharma

Hilary Groom

Leonard G. Luyt

See next page for additional authors

Follow this and additional works at: https://ir.lib.uwo.ca/chempub

Part of the Chemistry Commons

Citation of this paper:

Maar, Ryan R.; Barbon, Stephanie M.; Sharma, Neha; Groom, Hilary; Luyt, Leonard G.; and Gilroy, Joe, "Evaluation of AnisoleSubstituted Boron Difluoride Formazanate Complexes for Fluorescence Cell Imaging" (2015). Chemistry Publications. 69.

https://ir.lib.uwo.ca/chempub/69 
Authors

Ryan R. Maar, Stephanie M. Barbon, Neha Sharma, Hilary Groom, Leonard G. Luyt, and Joe Gilroy 


\title{
Evaluation of Anisole-Substituted Boron Difluoride Formazanate Complexes for Fluorescence Cell Imaging
}

\author{
Ryan R. Maar, ${ }^{[a, b]}$ Stephanie M. Barbon, ${ }^{[a, b]}$ Neha Sharma, ${ }^{[a]}$ Hilary Groom, ${ }^{[c]}$ Leonard G. Luyt, ${ }^{*[a, c, d]}$ \\ and Joe B. Gilroy*a,b]
}

\begin{abstract}
The evaluation of three subclasses of boron difluoride formazanate complexes bearing $0_{-}, m$-, and $p$-anisole $\mathrm{N}$-aryl substituents (Ar) as readily accessible alternatives to boron dipyrromethene (BODIPY) dyes for cell imaging applications is described. While the wavelengths of maximum absorption $\left(\lambda_{\max }\right)$ and emission $\left(\lambda_{\text {em }}\right)$ observed for each subclass of complexes, which differed by their carbon-bound substituents $(R)$, were similar, the emission quantum yields for $\mathbf{7 a}-\mathbf{c}(\mathrm{R}=$ cyano) were enhanced relative to $\mathbf{8 a}-\mathbf{c}(\mathrm{R}=$ nitro) and $\mathbf{9 a}-\mathrm{c}(\mathrm{R}=$ phenyl). Complexes $\mathbf{7 a - c}$ and $\mathbf{8 a}-\mathbf{c}$ were also significantly easier to reduce electrochemically to their radical anion and dianion forms compared to 9a-c. Within each subclass, the $o$-substituted derivatives were more difficult to reduce, had shorter $\lambda_{\max }$ and $\lambda_{\mathrm{em}}$, and lower emission quantum yields than the $p$-substituted analogs as a result of sterically-driven twisting of the $\mathrm{N}$-aryl substituents and a decrease in the degree of $\pi$ conjugation. The $m$-substituted complexes were the least difficult to reduce and possessed intermediate $\lambda_{\max }, \lambda_{\mathrm{em}}$, and quantum yields. The complexes studied also exhibited large Stokes shifts (82-152 $\left.\mathrm{nm}, 2143-5483 \mathrm{~cm}^{-1}\right)$. Finally, the utility of complex $7 \mathrm{c}(\mathrm{Ar}=p$ anisole, $R=$ cyano), which can be prepared for just a few dollars per gram, for fluorescence cell imaging was demonstrated. The use of 7c and 4',6-diamino-2-phenylindole (DAPI) allowed for simultaneous imaging of the cytoplasm and nucleus of mouse fibroblast cells.
\end{abstract}

\section{Introduction}

Boron difluoride $\left(\mathrm{BF}_{2}\right)$ chelates of $\mathrm{N}$-donor ligands are among the most widely studied classes of molecular materials due to their unique, tunable, and potentially useful absorption, emission, and electrochemical properties. ${ }^{[1],[2]}$ These compounds, including the ubiquitous boron dipyrromethanes (BODIPYs) $1,^{[3]}$ have shown utility as sensors, ${ }^{[4],[5]}$ as efficient electrochemiluminescence luminophores, ${ }^{[6],[7]}$ as the functional component of organic electronics, ${ }^{[8]}$ in photodynamic

[a] R.R. Maar, S.M. Barbon, N. Sharma, Prof. Dr. L.G. Luyt, and Prof. Dr. J.B. Gilroy

Department of Chemistry

The University of Western Ontario

1151 Richmond St. N., London, Ontario N6A 5B7 (Canada)

E-mail: lluyt@uwo.ca, joe.gilroy@uwo.ca

[b] R.R. Maar, S.M. Barbon, and Prof. Dr. J.B. Gilroy

The Centre for Advanced Materials and Biomaterials Research (CAMBR)

The University of Western Ontario

1151 Richmond St. N., London, Ontario N6A 5B7 (Canada)

[c] H. Groom and Prof. Dr. L.G. Luyt

Department of Oncology, London Regional Cancer Program

790 Commissioners Rd. E., London, Ontario N6A 4L6 (Canada)

[d] Prof. Dr. L.G. Luyt

Department of Medical Imaging

The University of Western Ontario

1151 Richmond St. N., London, Ontario N6A 5B7 (Canada)

Supporting information for this article is given via a link at the end of the document. therapy, ${ }^{[0],[10]}$ and perhaps most commonly, as fluorescence cell imaging agents. ${ }^{[11],[12]}$ Despite their widespread use in a broad range of applications, further development of the chemistry of many $\mathrm{BF}_{2}$ complexes has often been limited by their challenging synthesis and/or substantial cost. For example, a few milligrams of commercially available BODIPYs for cell imaging applications will often cost several hundred US dollars. Considering these factors, there remains a significant need for readily accessible molecular materials with similar or improved properties compared to BODIPYs that may be prepared via relatively simple, low-cost synthetic pathways.

$\mathrm{BF}_{2}$ formazanate complexes meet these criteria and offer the ability to tune spectroscopic and electrochemical properties through structural variation. ${ }^{[13]}$ The parent formazans $2,{ }^{[14]}$ known primarily for their use in cell viability assays, ${ }^{[15]}$ are typically prepared using aryl diazonium coupling reactions in aqueous media. They exist in three different conformations (i.e., 'closed', 'open', or 'linear') depending on the carbon-bound substituent (R) present. ${ }^{[14 a, 16]}$ In recent years, the coordination chemistry of formazanate ligands $\mathbf{3}$ has received significant attention due to the rich spectroscopic and redox properties exhibited by the resulting complexes. ${ }^{[17],[18]}$ However, their utility in practical applications such as cell imaging has not been demonstrated.

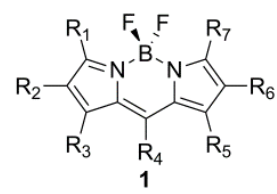
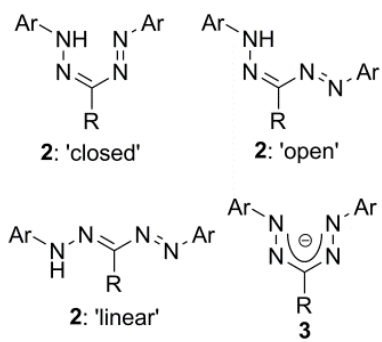

Herein, taking inspiration from the biocompatibility of formazans, we present a study designed to evaluate a series of anisole-substituted $\mathrm{BF}_{2}$ formazanate complexes $(\mathrm{Ar}=0$-anisole, $m$-anisole, $p$-anisole; $\mathrm{R}=$ cyano, nitro, phenyl) in an effort to showcase their utility as fluorescence cell imaging agents.

\section{Results and Discussion}

\section{Synthesis}

Anisole-substituted formazans $\mathbf{4 a - c}, \mathbf{5 a}-\mathbf{c}$, and $\mathbf{6 a - c}$ were prepared by adapting established procedures for the coupling of aryl diazonium salts and activated methylenes such as cyanoacetic acid, nitromethane, and phenylpyruvic acid in yields ranging from $18-90 \% .{ }^{[16,19]}$ It is worth noting that the variability in 
reaction yields relates mainly to the unpredictable stability of the aryl diazonium salts involved. ${ }^{[20]} 3$-Cyanoformazans $4 \mathbf{b}-\mathbf{d}$ exist primarily in the 'open' conformation in solution due to the presence of a linear carbon-bound cyano substituent and were identified by their characteristic orange color [wavelength of maximum absorption $\left(\lambda_{\max }\right): 419-453 \mathrm{~nm}$ ] and the chemical shift of the ${ }^{1} \mathrm{H}$ NMR resonance originating from their $\mathrm{NH}$ protons $(\delta$ : 11.75-12.89). All other formazans produced during this study exist in the more common 'closed' conformation in solution and exhibit characteristic $\mathrm{NH}$ resonances in their ${ }^{1} \mathrm{H}$ NMR spectra between 13.91 and 15.56 ppm and $\lambda_{\max }$ values between 448 and $530 \mathrm{~nm}$ in their UV-vis absorption spectra.

$\mathrm{BF}_{2}$ formazanate complexes $\mathbf{7 a - d}, \mathbf{8 a}-\mathbf{c}$, and $\mathbf{9 a - c}$ were prepared by heating the appropriate formazan in toluene with an excess of triethylamine and boron trifluoride diethyl etherate (Scheme 1, Table 1, Figures S1-S36). The isolated yields for the complexes ranged from $15-91 \%$ and were highly dependent on the purification methods employed. All new $\mathrm{BF}_{2}$ formazanate complexes were fully characterized by ${ }^{1} \mathrm{H},{ }^{11} \mathrm{~B},{ }^{13} \mathrm{C}$, and ${ }^{19} \mathrm{~F}$ NMR spectroscopy, UV-vis absorption and emission spectroscopy, IR spectroscopy, and high-resolution mass spectrometry. The formation of the $\mathrm{BF}_{2}$ complexes was accompanied by the disappearance of the $\mathrm{NH}$ resonance in their ${ }^{1} \mathrm{H}$ NMR spectra, and the appearance of a 1:2:1 triplet and a 1:1:1:1 quartet in their ${ }^{11} \mathrm{~B}$ and ${ }^{19} \mathrm{~F}$ NMR spectra, respectively. With the exception of $7 \mathrm{a}(\mathrm{Ar}=\mathrm{o}$-anisole, $\mathrm{R}=$ cyano $)$, the $\mathrm{BF}_{2}$ complexes were stable towards hydrolysis. In the presence of 10 equivalents of water, complex 7a slowly hydrolyzed to re-form the parent formazan $4 a$ ( $4 \%$ degradation after $48 \mathrm{~h}, 8 \%$ degradation after $96 \mathrm{~h})$. By comparison, complex $7 \mathbf{d}(\mathrm{Ar}=$ o-ethylbenzene, $\mathrm{R}=$ cyano) was indefinitely stable towards hydrolysis under the same conditions. Based on this comparison, we conclude that the hydrolysis of $7 \mathbf{a}$ is not driven by steric interactions alone, but rather that the lone pairs on oxygen likely play an important role in the decomposition pathway. Furthermore, the presence of the linear carbon-bound cyano substituent in 7a may facilitate its decomposition as it potentially allows for 'open' and 'linear' ligand arrangements to be accessed. Similar ligand orientations are less likely for reaction intermediates derived from complexes $8 \mathbf{a}$ and $9 \mathbf{a}$, which possess non-linear nitro and phenyl carbonbound substituents.

\section{X-ray Crystallography}

Single crystals of complexes $7 \mathbf{a}$ and $\mathbf{7 b}$ suitable for X-ray diffraction studies were grown by slow evaporation of saturated dichloromethane solutions in a sealed vessel containing hexanes. In the solid-state $7 \mathbf{a}$ and $\mathbf{7 b}$ exist in 'dragonfly' conformations, with the nitrogen-nitrogen and carbon-nitrogen bond lengths of the formazanate ligand backbone falling between those typically associated with single and double bonds of the same atoms (Figure 1, Table 2). ${ }^{[21]}$ The $\mathrm{N}$-aryl substituents are bent out of plane relative to the $\mathrm{N}_{4}$ backbone of the formazanate ligands by an average torsion angle of 61.2 and $47.7^{\circ}$ for $7 \mathrm{a}$ and $7 \mathrm{~b}$, respectively. The boron atoms reside 0.54 and $0.50 \AA$ out of the $\mathrm{N}_{4}$ plane in the structures of $7 \mathrm{a}$ and $7 \mathbf{b}$.

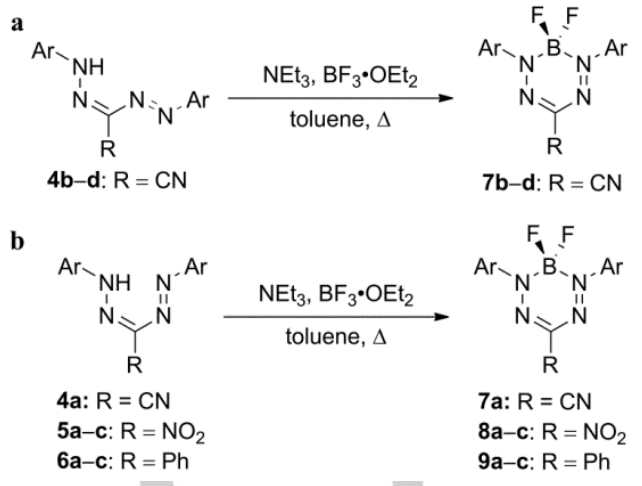

Scheme 1. General synthetic approach for the synthesis of $\mathrm{BF}_{2}$ formazanate complexes $7 \mathbf{b}-\mathbf{d}$ (a) and $\mathrm{BF}_{2}$ formazanate complexes $7 \mathrm{a}, \mathbf{8 a}-\mathbf{c}$ and $9 \mathrm{a}-\mathrm{c}$ (b) See Table 1 for a detailed list of substituents.

Table 1. Substituents for formazans $4 \mathbf{a}-\mathbf{d}, \mathbf{5 a - c}$, and $\mathbf{6 a - c}$ and $\mathrm{BF}_{2}$

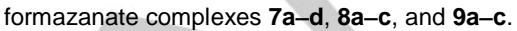

\begin{tabular}{ccc}
\hline Compound & Ar & $\mathbf{R}$ \\
\hline $4 a / 7 a$ & $o$-anisole & cyano \\
$4 b / 7 b$ & $m$-anisole & cyano \\
$4 c / 7 c$ & $p$-anisole & cyano \\
$4 d / 7 d$ & $o$-ethylbenzene & cyano \\
$5 a / 8 a$ & $o$-anisole & nitro \\
$5 b / 8 b$ & $m$-anisole & nitro \\
$5 c / 8 c$ & $p$-anisole & nitro \\
$6 a / 9 a$ & $o$-anisole & phenyl \\
$6 b / 9 b$ & $m$-anisole & phenyl \\
$6 c / 9 c$ & $p$-anisole & phenyl \\
\hline
\end{tabular}

These values are substantially larger than the torsion angles of 18.3 and $37.1^{\circ}$ and boron displacements of 0.13 and $0.34 \AA$ observed for the two crystallographically independent forms of 7c. ${ }^{[13 b]}$ Initially, we were tempted to rationalize these trends through steric arguments, whereby interactions between the 0 -, and to a lesser extent, $m$-methoxy groups and the fluorine atoms may lead to twisting of the $\mathrm{N}$-aryl substituents relative to the formazanate backbone. While this interpretation appears to hold true for $7 \mathrm{a}(\mathrm{Ar}=\mathrm{o}$-anisole, $\mathrm{R}=$ cyano), the large torsion angles observed for $\mathbf{7 b}(\mathrm{Ar}=m$-anisole, $\mathbf{R}=$ cyano) likely arise due to crystal packing effects including slipped $\pi$-stacking interactions (Figure S37). This conclusion is further corroborated by the fact that the methoxy substituents are anti to the $\mathrm{BF}_{2}$ moiety in the solid-state structure of $\mathbf{7 b}$.

\section{Cyclic Voltammetry}

The electrochemical properties of $\mathrm{BF}_{2}$ complexes $7 \mathrm{a}-\mathrm{c}$ were studied using cyclic voltammetry (Figure 2 and S38, Table 3). Each complex underwent two reversible one-electron reductions to form the corresponding ligand-centered radical anion and dianion (Scheme 2), while 7c was the only complex in the series that was oxidized (irreversibly) within the electrochemical window offered by acetonitrile. We have previously shown that electron-donating $\mathrm{N}$-aryl substituents render $\mathrm{BF}_{2}$ formazanate 
a

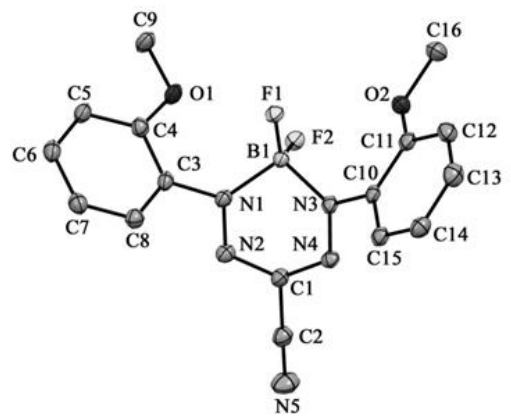

b

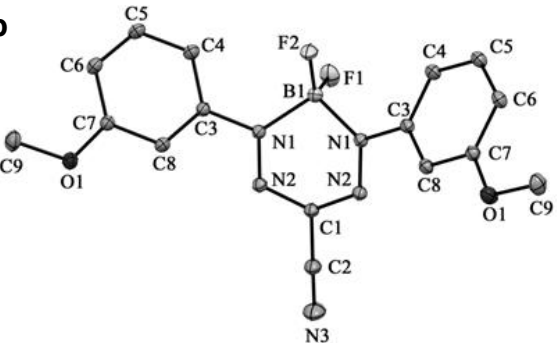

Figure 1. Solid-state structures of complexes 7a (a) and 7b (b). Anisotropic displacement ellipsoids are shown at $50 \%$ probability and hydrogen atoms have been omitted for clarity.

Table 2. Selected bond lengths $(\AA)$ and angles $(\mathrm{deg})$ for $B F_{2}$ formazanate complexes $7 a-c$.

\begin{tabular}{|c|c|c|c|c|}
\hline & $7 a$ & $7 b$ & & \\
\hline $\mathrm{N} 1-\mathrm{N} 2$ & $1.3040(16)$ & $1.2987(6)$ & $1.307(2)$ & $1.306(2)$ \\
\hline N3-N4 & $1.3038(16)$ & - & $1.304(2)$ & $1.302(2)$ \\
\hline $\mathrm{C} 1-\mathrm{N} 2$ & $1.3404(19)$ & $1.3443(5)$ & $1.340(3)$ & $1.335(3)$ \\
\hline $\mathrm{C} 1-\mathrm{N} 4$ & $1.3438(18)$ & - & $1.335(3)$ & $1.340(3)$ \\
\hline $\mathrm{N} 1-\mathrm{N} 2-\mathrm{C} 1$ & $116.09(11)$ & $116.42(4)$ & $116.75(18)$ & $116.21(17)$ \\
\hline N1-B1-N3 & $101.99(10)$ & - & $106.85(17)$ & $104.75(16)$ \\
\hline $\mathrm{N} 1-\mathrm{B} 1-\mathrm{N} 1{ }^{\prime}$ & - & $102.63(5)$ & - & - \\
\hline $\mathrm{N} 2-\mathrm{C} 1-\mathrm{N} 4$ & $126.85(12)$ & - & $130.0(2)$ & $129.32(18)$ \\
\hline $\mathrm{N} 2^{\prime}-\mathrm{C} 1-\mathrm{N} 2$ & - & $127.22(6)$ & - & - \\
\hline $\begin{array}{l}\text { boron } \\
\text { displacement }^{[\mathrm{b}]}\end{array}$ & 0.54 & 0.50 & 0.13 & 0.34 \\
\hline dihedral angles $^{[\mathrm{c}]}$ & $62.0,60.5$ & $47.7,47.7$ & $15.3,21.4$ & $37.6,36.6$ \\
\hline
\end{tabular}

[a] The asymmetric unit determined for $\mathrm{BF}_{2}$ complex 7c contains two unique molecules. [b] Distance between $\mathrm{B} 1$ and the $\mathrm{N}_{4}$ plane. [c] Torsion angle between $\mathrm{N} 1$ and $\mathrm{N} 3$ aryl substituents and the $\mathrm{N}_{4}$ plane.

complexes more difficult to reduce than the phenyl-substituted analogs, and that the opposite is true for complexes bearing electron-withdrawing substituents. ${ }^{[13 \mathrm{~b}, c]}$ In the present study, the interpretation is slightly more complex as both steric and electronic effects must be considered. Complexes 7a and 7c possess anisole substituents with $o$ - and $p$-substitution patterns, which potentially allow for resonance donation of oxygen lone pairs leading to extended $\pi$ conjugation of the formazanate framework. The $m$-substituted complex $\mathbf{7 b}$ is not resonance delocalized, and should therefore possess properties purely associated with the inductive electron-withdrawing character of the methoxy group. Indeed, $\mathbf{7 b}$ is the easiest complex to reduce within the series $\left(E_{\text {red1 }}^{\circ}=-0.50 \mathrm{~V} ; E_{\text {red2 }}^{\circ}=-1.62 \mathrm{~V}\right.$ vs. ferrocene/ferrocenium). The 0 -substituted complex $7 \mathbf{a}$ was observed to be more difficult to reduce $\left(E_{\text {red1 }}^{\circ}=-0.73 \mathrm{~V} ; E_{\text {red2 }}^{\circ}=\right.$ $-1.88 \mathrm{~V})$ than the $p$-substituted complex $7 \mathrm{c}\left(E_{\text {red1 }}^{\circ}=-0.68 \mathrm{~V}\right.$; $\left.E_{\text {red2 }}^{\circ}=-1.82 \mathrm{~V}\right)$. We attribute this behavior to twisting of the 0 anisole substituents relative to the formazanate backbone in $\mathbf{7 a}$ in solution. This twisting, which is consistent with the solid-state structure described above, limits the degree of $\pi$ conjugation of the formazanate framework. The reduced degree of $\pi$ conjugation results in destabilization of the lowest unoccupied molecular orbital (LUMO), and, in turn, renders 7a more difficult to reduce than the $\pi$ conjugated complex $7 \mathrm{c}$. This argument is supported by DFT studies that showed the LUMO orbital of closely related complexes to include both the formazanate backbone and $N$-aryl substituents. ${ }^{[13 b, 13 d]}$ In order to confirm that the effect of the substituent pattern on the electrochemical properties of anisole-substituted $\mathrm{BF}_{2}$ formazanate complexes was general, cyclic voltammograms were also collected for $\mathbf{8 a - c}$ ( $R=$ nitro) and 9a-c ( $R=$ phenyl) (Figures S39 and S40, Table 3). Nitro-substituted complexes $\mathbf{8 a - c}$ were slightly easier to reduce than the corresponding cyano-substituted complexes due to the strong electron-withdrawing nature of the nitro group, while phenyl-substituted complexes 9a-c were much more difficult to reduce due to the absence of a strongly electronwithdrawing carbon-bound substituent on the formazanate backbone. For each series, the $m$-substituted complexes were the easiest to reduce and the o-substituted complexes were more difficult to reduce than the $p$-analogs, confirming that the trend discussed above is general.

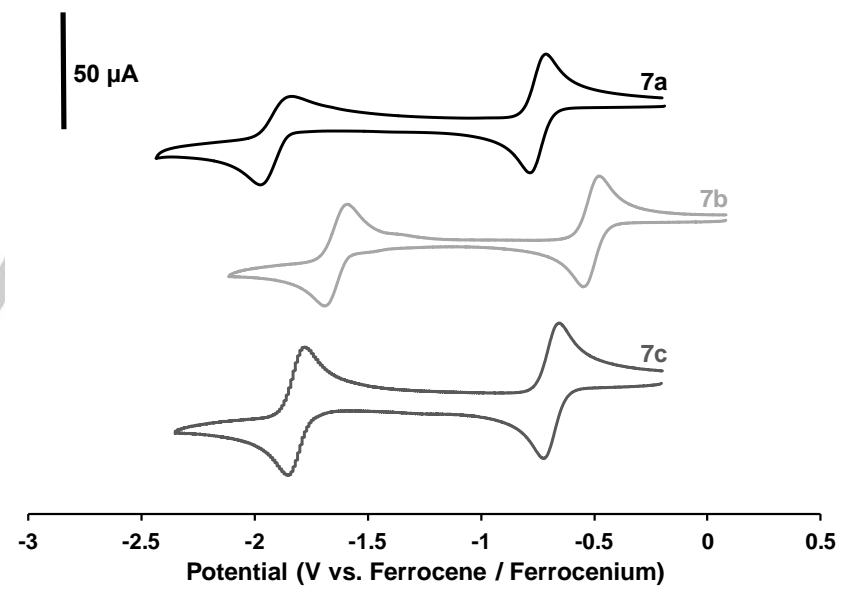

Figure 2. Cyclic voltammograms for $\mathrm{BF}_{2}$ formazanate complexes $7 \mathrm{a}(\mathrm{Ar}=0$ anisole, $\mathrm{R}=$ cyano), $\mathbf{7 b}(\mathrm{Ar}=m$-anisole, $\mathrm{R}=$ cyano $)$, and $7 \mathbf{c}(\mathrm{Ar}=p$-anisole, $\mathrm{R}$ = cyano) recorded in dry, degassed acetonitrile containing $\sim 1 \mathrm{mM}$ analyte and $0.1 \mathrm{M} \mathrm{n}-\mathrm{Bu}_{4} \mathrm{NPF}_{6}$ at a scan rate of $100 \mathrm{mV} \mathrm{s}^{-1}$

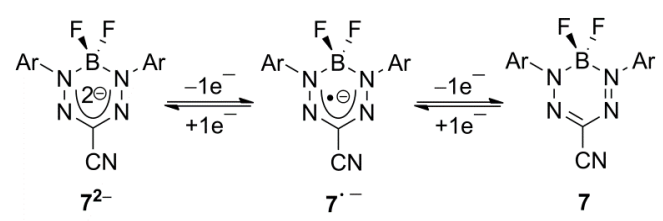

Scheme 2. Electrochemical reduction of $\mathrm{BF}_{2}$ formazanate complexes $\mathbf{7 a}, \mathbf{7 b}$ and $7 \mathrm{c}(\mathrm{Ar}=o$-anisole, $m$-anisole, or $p$-anisole $)$. 
Table 3. Solution characterization data for $\mathrm{BF}_{2}$ complexes $\mathbf{7 a - d}, \mathbf{8 a}-\mathbf{c}$, and $\mathbf{9 a}-\mathbf{c}$

\begin{tabular}{|c|c|c|c|c|c|c|c|c|c|}
\hline & solvent & $\begin{array}{l}\lambda_{\max } \\
(\mathbf{n m})\end{array}$ & $\left(\mathrm{M}^{-1} \mathrm{~cm}^{\varepsilon}\right)$ & $\begin{array}{c}\lambda_{\mathrm{em}} \\
(\mathrm{nm})\end{array}$ & $\Phi_{\mathrm{f}}^{a}$ & $\begin{array}{c}U_{\mathrm{ST}} \\
(\mathrm{nm})\end{array}$ & $\begin{array}{c}U_{S T} \\
\left(\mathrm{~cm}^{-1}\right)\end{array}$ & $\begin{array}{c}E_{\text {red1 }}^{\circ} \\
\text { (V) }\end{array}$ & $\begin{array}{c}E_{\text {red22 }}^{\circ} \\
\text { (V) }\end{array}$ \\
\hline \multicolumn{10}{|l|}{$\mathbf{R}=$ cyano } \\
\hline & THF & 456 & 10,100 & 590 & 0.03 & 134 & 4981 & & \\
\hline \multirow[t]{2}{*}{$(\mathrm{Ar}=0$-anisole $)$} & $\mathrm{CH}_{2} \mathrm{Cl}_{2}$ & 466 & 15,500 & 589 & 0.04 & 123 & 4481 & -0.73 & -1.88 \\
\hline & toluene & 467 & 16,000 & 592 & 0.05 & 125 & 4521 & & \\
\hline $7 b$ & THF & 510 & 20,000 & 639 & 0.01 & 129 & 3958 & & \\
\hline \multirow[t]{2}{*}{$(\mathrm{Ar}=m$-anisole $)$} & $\mathrm{CH}_{2} \mathrm{Cl}_{2}$ & 517 & 18,500 & 637 & 0.03 & 120 & 3644 & -0.50 & -1.62 \\
\hline & toluene & 525 & 21,100 & 635 & 0.13 & 110 & 3300 & & \\
\hline $7 c^{[13 b]}$ & THF & 556 & 33,400 & 662 & 0.46 & 106 & 2880 & & \\
\hline$(\mathrm{Ar}=p$-anisole $)$ & toluene & 572 & 42,700 & 656 & 0.77 & 84 & 2239 & & \\
\hline $7 d$ & THF & 433 & 12,000 & 562 & 0.01 & 129 & 5301 & & \\
\hline \multirow{2}{*}{$(\mathrm{Ar}=0$-ethylbenzene $)$} & $\mathrm{CH}_{2} \mathrm{Cl}_{2}$ & 431 & 14,300 & 562 & 0.02 & 131 & 5408 & -0.66 & -1.86 \\
\hline & toluene & 436 & 14,000 & 565 & 0.02 & 129 & 5236 & & \\
\hline \multicolumn{10}{|l|}{$\mathbf{R}=$ nitro } \\
\hline & THF & 456 & 5,900 & 608 & 0.03 & 152 & 5483 & & \\
\hline \multirow[t]{2}{*}{$(\mathrm{Ar}=0$-anisole $)$} & $\mathrm{CH}_{2} \mathrm{Cl}_{2}$ & 466 & 7,100 & 599 & 0.03 & 133 & 4768 & -0.71 & -1.83 \\
\hline & toluene & 468 & 7,500 & 603 & 0.05 & 135 & 4784 & & \\
\hline $8 b$ & THF & 512 & 17,700 & 656 & $<0.01$ & 144 & 4287 & & \\
\hline $8 c$ & THF & 559 & 26,700 & 667 & 0.17 & 108 & 2897 & & \\
\hline \multirow[t]{2}{*}{$(\mathrm{Ar}=p$-anisole $)$} & $\mathrm{CH}_{2} \mathrm{Cl}_{2}$ & 564 & 20,100 & 665 & 0.24 & 101 & 2693 & -0.60 & -1.72 \\
\hline & toluene & 572 & 23,600 & 661 & 0.33 & 82 & 2143 & & \\
\hline \multicolumn{10}{|l|}{$R=$ phenyl } \\
\hline & THF & 459 & 18,900 & 592 & $<0.01$ & 133 & 4895 & & \\
\hline \multirow[t]{2}{*}{$(\mathrm{Ar}=o$-anisole $)$} & $\mathrm{CH}_{2} \mathrm{Cl}_{2}$ & 464 & 21,600 & 588 & 0.01 & 124 & 4545 & -1.09 & -1.97 \\
\hline & toluene & 467 & 18,800 & 596 & $<0.01$ & 129 & 4635 & & \\
\hline $9 b$ & THF & 520 & 25,000 & 643 & $<0.01$ & 123 & 3679 & & \\
\hline \multirow{2}{*}{$(\mathrm{Ar}=m$-anisole $)$} & $\mathrm{CH}_{2} \mathrm{Cl}_{2}$ & 521 & 25,000 & 644 & 0.025 & 123 & 3666 & -0.81 & -1.87 \\
\hline & toluene & 530 & 22,900 & 644 & 0.012 & 114 & 3340 & & \\
\hline 9c & THF & 548 & 23,400 & 672 & 0.019 & 124 & 3367 & & \\
\hline \multirow{2}{*}{$(\mathrm{Ar}=p$-anisole $)$} & $\mathrm{CH}_{2} \mathrm{Cl}_{2}$ & 545 & 29,300 & 670 & 0.063 & 125 & 3423 & -0.94 & -1.93 \\
\hline & toluene & 551 & 25,500 & 672 & 0.028 & 121 & 3268 & - & \\
\hline
\end{tabular}

\section{UV-vis Absorption and Emission Spectroscopy}

The UV-vis absorption and emission spectra for $\mathrm{BF}_{2}$ complexes 7a-c $(R=$ cyano) are shown in Figure 3 and the data summarized in Table 3 . Each of the complexes is strongly absorbing within the visible region of the electromagnetic spectrum with wavelengths of maximum absorption $\left(\lambda_{\max }\right)$ ranging from 467 to $572 \mathrm{~nm}$ and molar extinction coefficients $(\varepsilon)$ ranging from 16,000 to $42,700 \mathrm{M}^{-1} \mathrm{~cm}^{-1}$ in toluene. The lowenergy absorption maxima for a similar set of complexes was shown by time-dependent DFT to involve primarily the highest occupied molecular orbital (HOMO)-LUMO transition. ${ }^{[13 d]}$ The same series of compounds exhibited wavelengths of maximum emission $\left(\lambda_{\text {em }}\right)$ ranging from 592 to $656 \mathrm{~nm}$ and quantum yields $\left(\Phi_{f}\right)$ ranging from 0.05 to 0.77 . As a result of the twisted conformation adopted by the $\mathrm{N}$-aryl substituents, and the reduced degree of $\pi$ conjugation that results, the $o$-substituted complex $7 \mathrm{a}$ had the lowest values of $\lambda_{\max }(467 \mathrm{~nm}), \varepsilon(16,000$ $\left.\mathrm{M}^{-1} \mathrm{~cm}^{-1}\right), \lambda_{\mathrm{em}}(592 \mathrm{~nm})$, and $\Phi_{\mathrm{f}}(0.05)$. Conversely, $p$-substituted complex 7c possessed properties consistent with extended $\pi$ conjugation arising from the relatively coplanar orientation of the $\mathrm{N}$-aryl substituents and the formazanate backbone $\left(\lambda_{\max }=572\right.$ $\mathrm{nm} ; \varepsilon=42,700 \mathrm{M}^{-1} \mathrm{~cm}^{-1} ; \lambda_{\mathrm{em}}=656 \mathrm{~nm} ;$ and $\left.\Phi_{\mathrm{f}}=0.77\right)$. The spectroscopic characteristics of the $m$-substituted analog $7 \mathbf{b}$ fall between those observed for $7 a$ and $7 c$ and are dictated by the presence of the inductively electron-withdrawing methoxy group $\left(\lambda_{\max }=525 \mathrm{~nm} ; \varepsilon=21,100 \mathrm{M}^{-1} \mathrm{~cm}^{-1} ; \lambda_{\text {em }}=635 \mathrm{~nm}\right.$; and $\Phi_{\mathrm{f}}=$ 0.13). Complex $\mathbf{7 d}$, which has o-ethylbenzene $N$-aryl substituents, has $\lambda_{\max }=436 \mathrm{~nm}$ and $\varepsilon=14,000 \mathrm{M}^{-1} \mathrm{~cm}^{-1}$, confirming that the twisted structure postulated for $7 \mathbf{a}$ is not unique to anisole-substituted compounds, and is driven by steric interactions (Figure S42). The spectroscopic properties
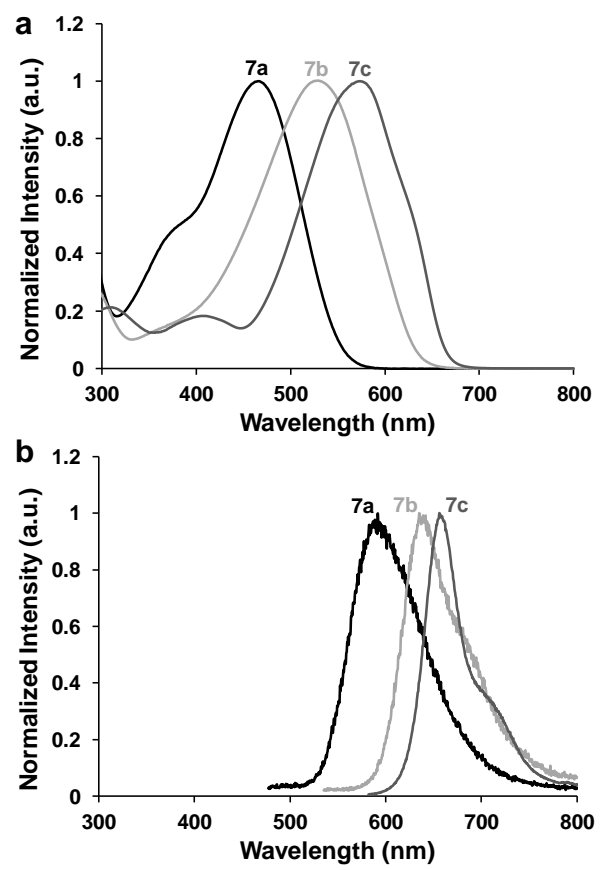

Figure 3. UV-vis absorption spectra (a) and emission spectra (b) for $\mathrm{BF}_{2}$ formazanate complexes $7 \mathrm{a}(\mathrm{Ar}=0$-anisole, $\mathrm{R}=$ cyano), $\mathbf{7 b}(\mathrm{Ar}=m$-anisole, $\mathrm{R}$ $=$ cyano $)$, and $7 c(A r=p$-anisole, $\mathrm{R}=$ cyano $)$ recorded for degassed $10 \mu \mathrm{M}$ toluene solutions. 
observed for complexes $\mathbf{8} \mathbf{a}-\mathbf{c}(\mathrm{R}=$ nitro $)$ and $9 \mathbf{a}-\mathbf{c}(\mathrm{R}=$ phenyl) were closely related to those of $7 \mathbf{a}-\mathbf{c}$, further demonstrating the generality of the trend observed (Figures S43 and S44). However, it must be noted that the emission quantum yields calculated for $\mathbf{8 a}-\mathbf{c}$ and $\mathbf{9 a}-\mathbf{c}$, were lower than those calculated for $\mathbf{7 a - c . ~ I n ~ p a r t i c u l a r , ~ 9 a - c ~ a r e ~ w e a k l y ~ e m i s s i v e , ~ l i k e l y ~ a s ~ a ~}$ result of non-radiative decay pathways associated with the carbon-bound phenyl substituent. Each of the anisolesubstituted $\mathrm{BF}_{2}$ complexes reported in this study exhibited large Stokes shifts (UST) ranging from 82 to $152 \mathrm{~nm}\left(2143-5483 \mathrm{~cm}^{-1}\right)$. This key characteristic of $\mathrm{BF}_{2}$ formazanate complexes is of significant importance to their potential use as fluorescence cell imaging agents, where photon re-absorption greatly limits emission intensity.

\section{Cell Imaging}

Based on our evaluation of the anisole-substituted $\mathrm{BF}_{2}$ formazanate complexes described above, we concluded that complex 7c, which can be prepared in two straightforward synthetic steps involving minimal bench time for just a few dollars per gram, was an excellent candidate for fluorescence cell-imaging studies. To this end, the uptake of complex 7c into fibroblast cells was investigated (Figure 4).

Mouse fibroblast cells were incubated with 7c for one hour, and after washing and fixing, were imaged by confocal fluorescence microscopy.
The fluorescence images demonstrated that 7c was internalized by the fibroblast cells (Figure 4a,b). As a result of the low-energy $\left(\lambda_{\mathrm{em}} \sim 660 \mathrm{~nm}\right)$ emission of 7c, this dye proved to be well suited for orthogonal imaging applications. We explored this potential by co-staining cells with the nuclear dye 4',6-diamidino-2phenylindole (DAPI), and demonstrated that 7c and DAPI could be used to image the cell cytoplasm and nucleus simultaneously (Figure $4 \mathrm{c}, \mathrm{d}$ ). During the course of these studies, we frequently observed punctate staining, which could be due to the dye being localized in either the endoplasmic reticulum and/or vesicles. Aggregation of the dye could be another possible explanation for the punctate appearance. However, we were able to rule out aggregation induced emission enhancement by adding water to tetrahydrofuran solutions of $\mathbf{7 c}$, and demonstrating that emission intensity decreases as the volume fraction of water is increased and aggregates begin to form (Figure S45). We therefore conclude that the punctate staining is due to high local concentration of $7 \mathrm{c}$ rather than aggregation.

\section{Conclusions}

We have systematically evaluated a library of $o-, m$-, and $p$ anisole-substituted $\mathrm{BF}_{2}$ formazanate complexes, and, for the first time, demonstrated their potential as readily accessible fluorescence imaging agents. The substitution pattern for each
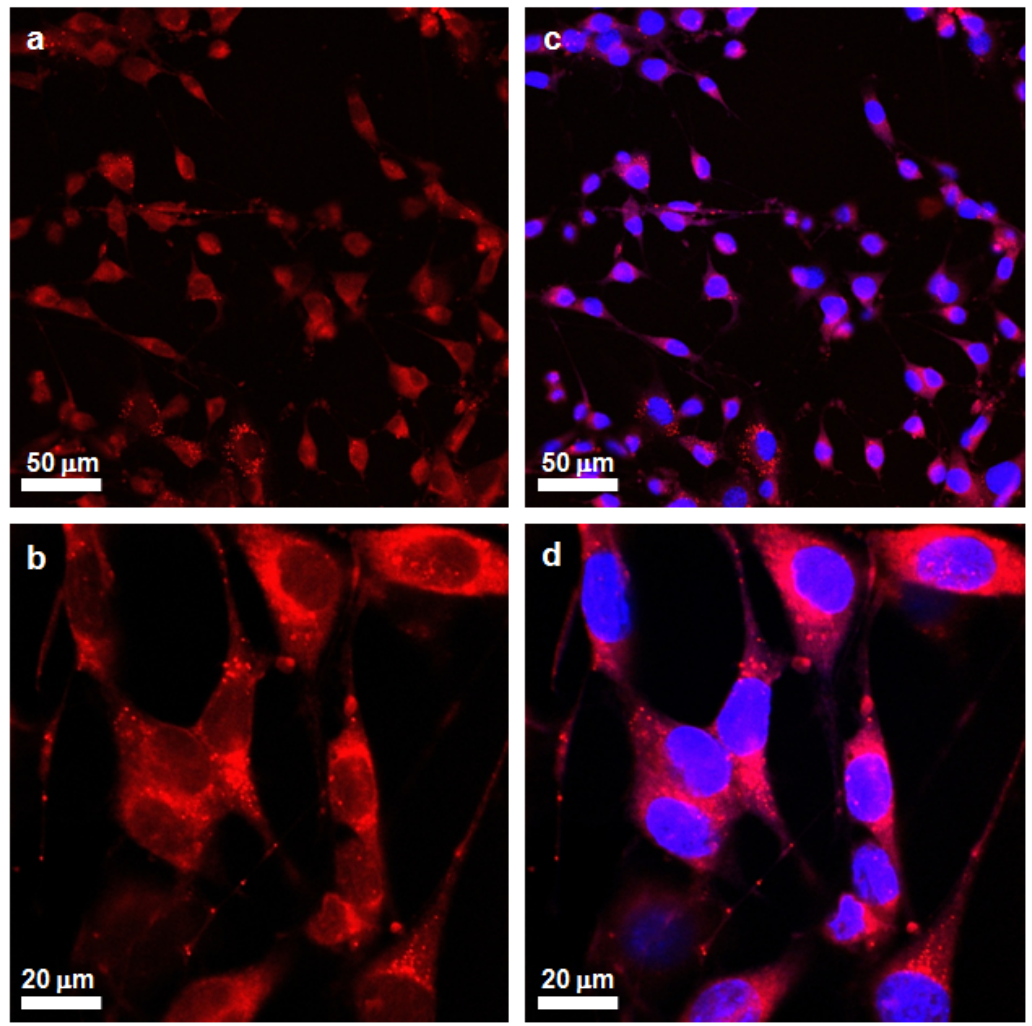

Figure 4. Confocal fluorescence micrographs of mouse fibroblast cells stained with $\mathrm{BF}_{2}$ formazanate complex 7c and DAPI. Images (a) and (b) were visualized with excitation at $559 \mathrm{~nm}$ and emission collected between 625-725 nm. Images (c) and (d) are an overlay of images (a) and (b) with those obtained from excitation at $405 \mathrm{~nm}$ and emission collected between $425-475 \mathrm{~nm}$. 
subset of complexes ( $R=$ cyano, nitro, and phenyl) was shown to have a dramatic effect on their electrochemical and spectroscopic properties. In each case, the o-substituted complexes were the most difficult to reduce electrochemically, had the shortest $\lambda_{\max }$ and $\lambda_{\text {em }}$, and possessed low emission quantum yields due to limited $\pi$ conjugation of the formazanate framework. By comparison, the p-substituted analogs were slightly easier to reduce electrochemically, had dramatically redshifted $\lambda_{\max }$ and $\lambda_{\mathrm{em}}$, and significantly enhanced emission quantum yields (up to 0.77). Each of these traits were consistent with extended $\pi$ conjugation between the formazanate backbone and the $\mathrm{N}$-aryl substituents. The spectroscopic properties of the $m$-substituted complexes, which were the easiest to reduce, were intermediate between those of the $o$ - and $p$-complexes, due to the absence of resonance delocalization of the oxygen lone pairs and the inductive electron withdrawing nature of the methoxy groups. Based on our evaluation, we were able to identify complex $7 \mathrm{c}(\mathrm{Ar}=p$-anisole, $\mathrm{R}=$ cyano $)$ as a strong candidate for use in fluorescence cell imaging applications. We subsequently demonstrated its efficacy as a fluorescent dye for orthogonal imaging of the cytoplasm (complex 7c) and nucleus (DAPI) of mouse fibroblast cells. Our future work in this area will expand on these results and focus on cell imaging applications involving disease-targeting $\mathrm{BF}_{2}$ formazanate dyes.

\section{Experimental Section}

\section{General Considerations}

All reactions were carried out under nitrogen atmosphere using standard Schlenk techniques unless otherwise stated. Reagents were purchased from Sigma-Aldrich or Alfa Aesar and used as received. Solvents were purchased from Caledon Laboratories, dried using an Innovative Technologies Inc. solvent purification system, collected under vacuum, and stored under inert (nitrogen) atmosphere containing $4 \AA$ molecular sieves. The synthesis and characterization of compounds $4 c$ and $7 c$ have been reported previously. ${ }^{[13 b]}$ NMR spectra were recorded on 400 $\mathrm{MHz}\left({ }^{1} \mathrm{H}: 399.8 \mathrm{MHz},{ }^{11} \mathrm{~B}: 128.3 \mathrm{MHz},{ }^{19} \mathrm{~F}: 376.1 \mathrm{MHz}\right)$ or $600 \mathrm{MHz}\left({ }^{1} \mathrm{H}\right.$ : $599.5 \mathrm{MHz},{ }^{13} \mathrm{C}$ : $150.8 \mathrm{MHz}$ ) Varian INOVA spectrometers. ${ }^{1} \mathrm{H}$ NMR spectra were referenced to residual $\mathrm{CHCl}_{3}(7.27 \mathrm{ppm})$ or $\left(\mathrm{CD}_{3}\right)\left(\mathrm{CD}_{2} \mathrm{H}\right) \mathrm{SO}$ (2.50 ppm) and ${ }^{13} \mathrm{C}$ NMR spectra were referenced to $\mathrm{CDCl}_{3}(77.0 \mathrm{ppm})$ or DMSO- $d_{6}(39.5 \mathrm{ppm}) .{ }^{11} \mathrm{~B}$ spectra were referenced to $\mathrm{BF}_{3} . \mathrm{OEt}_{2}$ at 0 $\mathrm{ppm}$, and ${ }^{19} \mathrm{~F}$ spectra were referenced to $\mathrm{CFCl}_{3}$ at $0 \mathrm{ppm}$. Mass spectrometry data were recorded in positive-ion mode using a highresolution Finnigan MAT 8200 spectrometer using electron impact ionization. UV-vis spectra were recorded using a Cary 300 Scan instrument. Molar extinction coefficients were determined from the slope of a plot of absorbance against concentration using four solutions with known concentrations ranging between 10 and $100 \mu \mathrm{M}$. Infrared spectra were recorded on a $\mathrm{KBr}$ disk using a Bruker Vector 33 FT-IR spectrometer. Emission spectra were obtained using a Photon Technology International QM-4 SE spectrofluorometer. Excitation wavelengths were chosen based on absorption maxima from the respective UV-vis spectrum in the same solvent. Quantum yields were calculated relative to ruthenium tris(bipyridine) hexafluorophosphate by methods described by Fery-Forgues and co-workers. ${ }^{[22]}$

\section{Electrochemical Methods}

Cyclic voltammetry experiments were performed with a Bioanalytical
Systems Inc. (BASi) Epsilon potentiostat and analyzed using BASi Epsilon software. Typical electrochemical cells consisted of a threeelectrode setup including a silver pseudo reference electrode, glassy carbon working electrode, and platinum counter electrode. Experiments were run at $100 \mathrm{mV} \mathrm{s}^{-1}$ scan rate in degassed acetonitrile solutions of the analyte $(\sim 1 \mathrm{mM})$ and electrolyte $(0.1 \mathrm{M}$ tetrabutylammonium hexafluorophosphate). Cyclic voltammograms were referenced relative to the ferrocene/ferrocenium redox couple $(\sim 1 \mathrm{mM}$ internal standard) and corrected for internal cell resistance using the BASi Epsilon software.

\section{X-ray Crystallography Methods}

Single crystals of $\mathbf{7 a}$ and $\mathbf{7 b}$ were mounted on a Mitegen polyimide micromount with a small amount of Paratone $\mathrm{N}$ oil. X-ray diffraction measurements for $7 \mathrm{a}$ were made on a Nonius KappaCCD Apex2 and measurements for $\mathbf{7 b}$ were made using Bruker a Kappa Axis Apex2 diffractometer. Both compounds were measured at a temperature of 110 $K$. The data collection strategy was a number of $\omega$ and $\varphi$ which collected data over a range of angles, $2 \theta$. The frame integration was performed using SAINT. ${ }^{[23]}$ The resulting raw data was scaled and absorption corrected using a multi-scan averaging of symmetry equivalent data using SADABS. ${ }^{[24]}$

The structures were solved by using a dual space methodology using the SHELXT program. ${ }^{[25]}$ All non-hydrogen atoms were obtained from the initial solution. The hydrogen atoms were introduced at idealized positions and were allowed to refine isotropically. The structural model was fit to the data using full matrix least-squares based on $F^{2}$. The calculated structure factors included corrections for anomalous dispersion from the usual tabulation. The structures were refined using the SHELXL-2014 program from the SHELXTL program package. ${ }^{[26]}$ See Table 4, the Supporting Information, and CCDC 1413166 and 1413167 for crystallographic details.

Table 4. X-ray diffraction data collection and refinement details for $\mathbf{7 a}$ and $\mathbf{7 b}$.

\begin{tabular}{|c|c|c|}
\hline & $7 a$ & $7 b$ \\
\hline $\begin{array}{l}\text { Chemical Formula } \\
\text { FW }\left(\mathrm{g} \mathrm{mol}^{-1}\right)\end{array}$ & $\begin{array}{c}\mathrm{C}_{16} \mathrm{H}_{14} \mathrm{BF}_{2} \mathrm{~N}_{5} \mathrm{O}_{2} \\
357.13\end{array}$ & $\begin{array}{c}\mathrm{C}_{16} \mathrm{H}_{14} \mathrm{BF}_{2} \mathrm{~N}_{5} \mathrm{O}_{2} \\
357.13\end{array}$ \\
\hline $\begin{array}{l}\text { Crystal Dimensions } \\
\qquad(\mathrm{mm})\end{array}$ & $0.411 \times 0.149 \times 0.104$ & $0.384 \times 0.324 \times 0.246$ \\
\hline Crystal Habit & red needle & purple prism \\
\hline Crystal System & monoclinic & monoclinic \\
\hline Space Group & $\mathrm{P} 2{ }_{1} / \mathrm{c}$ & $\mathrm{C} 2 / \mathrm{m}$ \\
\hline Temperature (K) & 110 & 110 \\
\hline$a(\AA)$ & $9.784(2)$ & $13.349(3)$ \\
\hline$b(\AA ̊)$ & $18.259(5)$ & $16.206(3)$ \\
\hline$c(\AA)$ & $10.150(2)$ & $8.1753(19)$ \\
\hline$\alpha\left(^{\circ}\right)$ & 90 & 90 \\
\hline$\beta\left(^{\circ}\right)$ & $111.382(6)$ & $112.872(10)$ \\
\hline $\begin{array}{l}Y\left({ }^{\circ}\right) \\
V\left(\AA^{3}\right)\end{array}$ & $\begin{array}{c}90 \\
1688.4(7)\end{array}$ & $\begin{array}{c}90 \\
1629.6(6)\end{array}$ \\
\hline Z & 4 & 4 \\
\hline$\rho\left(\mathrm{g} \mathrm{cm}^{-3}\right)$ & 1.405 & 1.456 \\
\hline$\lambda, \AA$ & $1.54178(\mathrm{CuK} \alpha)$ & $0.71073(\mathrm{MoK} \alpha)$ \\
\hline$\mu\left(\mathrm{cm}^{-1}\right)$ & 0.938 & 0.114 \\
\hline Diffractometer Type & $\begin{array}{c}\text { Nonius KappaCCD } \\
\text { Apex2 }\end{array}$ & $\begin{array}{c}\text { Bruker Kappa Axis } \\
\text { Apex2 }\end{array}$ \\
\hline$R_{\text {merge }}$ & 0.0380 & 0.0272 \\
\hline $\mathrm{R}_{1}[\mathrm{I}>2 \sigma(\mathrm{I})]$ & 0.0305 & 0.0387 \\
\hline$\omega \mathrm{R}_{2}[\mathrm{I}>2 \sigma(\mathrm{I})]$ & 0.0731 & 0.1127 \\
\hline $\mathrm{R}_{1}$ (all data) & 0.0376 & 0.0509 \\
\hline$\omega \mathrm{R}_{2}$ (all data) & 0.0768 & 0.1210 \\
\hline GOF & 1.054 & 1.058 \\
\hline
\end{tabular}

\section{Cell Imaging Protocols}

A stock solution of $\mathrm{BF}_{2}$ formazanate complex $7 \mathrm{c}$ in DMSO $(10 \mu \mathrm{M})$ was prepared and subsequently diluted with Dulbecco's modified Eagle's 
medium (DMEM) to obtain final concentrations of $0.5 \mu \mathrm{M}$ of dye. Mouse fibroblast $\mathrm{C} 3 \mathrm{H} / 10 \mathrm{~T} 1 / 2$ cells (ATCC, Manassas, VA) were released from the tissue culture flask by trypsinization and seeded onto cover slips in a 12-well tissue culture plate at an approximate cell density of 50,000 cells per well. The cells were incubated overnight in DMEM containing 10\% fetal bovine serum (FBS) at $37{ }^{\circ} \mathrm{C}$ in a $5 \% \mathrm{CO}_{2}$ atmosphere. The serum containing DMEM in each well was removed and replaced with serum free DMEM containing a concentration of $0.5 \mu \mathrm{M}$ of dye and incubated at $37^{\circ} \mathrm{C}$ for $1 \mathrm{~h}$. The cells were then washed three times with phosphate buffer saline (PBS), fixed with $4 \%$ paraformaldehyde and mounted onto slides containing Pro-Long Antifade mounting medium with DAPI. Images were then obtained using an Olympus FluoView FV 1000 confocal microscope.

\section{Representative Procedure for the Preparation of Formazans 4a, 4b,} and 4d

Formazan $4 a\left(\mathbf{A r}_{1}=\mathbf{A r}_{5}=\right.$ o-anisole, $\left.\mathbf{R}_{3}=\mathbf{C N}\right)$. In air, cyanoacetic acid $(2.40 \mathrm{~g}, 28.2 \mathrm{mmol})$ and sodium hydroxide $(11.4 \mathrm{~g}, 285 \mathrm{mmol})$ were dissolved in deionized water $(140 \mathrm{~mL})$. The resulting colorless solution was cooled to $0{ }^{\circ} \mathrm{C}$ and stirred for $2 \mathrm{~h}$. In a separate flask, $o$-anisidine $(6.92 \mathrm{~g}, 56.2 \mathrm{mmol})$ was combined with concentrated hydrochloric acid $(14.0 \mathrm{~mL}, 168 \mathrm{mmol})$ in deionized water $(55 \mathrm{~mL})$ and stirred for $1.5 \mathrm{~h}$ at $0{ }^{\circ} \mathrm{C}$. A solution of sodium nitrite $(5.83 \mathrm{~g}, 84.5 \mathrm{mmol})$ in deionized water $\left(17 \mathrm{~mL}\right.$ ) was cooled to $0^{\circ} \mathrm{C}$ in an ice bath for $1.5 \mathrm{~h}$ before it was added dropwise to the $o$-anisidine solution over a $25 \mathrm{~min}$ period. The resulting yellow-brown diazonium salt solution was stirred for $1 \mathrm{~h}$ at $0{ }^{\circ} \mathrm{C}$ before it was added to the alkaline cyanoacetic acid solution. Upon addition, the solution turned blood red and a precipitate of the same color formed. The mixture was left to warm slowly with stirring for $18 \mathrm{~h}$ before the solid was isolated by vacuum filtration. The filtrate was neutralized with $1 \mathrm{M} \mathrm{HCl}$ (ca. $150 \mathrm{~mL}$ ), extracted into dichloromethane $(3 \times 150 \mathrm{~mL})$, washed with deionized water $(3 \times 150 \mathrm{~mL})$, dried over $\mathrm{MgSO}_{4}$, gravity filtered, and concentrated in vacuo to afford a red solid. The crude solids were combined and purified by flash column chromatography (dichloromethane, neutral alumina) and recrystallized from a saturated methanolic solution to afford formazan $4 \mathrm{a}$ as red needles. Yield $=6.10 \mathrm{~g}$, $70 \%$. M.p. $136-138{ }^{\circ} \mathrm{C} .{ }^{1} \mathrm{H}$ NMR $\left(599.5 \mathrm{MHz}, \mathrm{CDCl}_{3}\right): \delta 13.91$ (s, $1 \mathrm{H}$, $\mathrm{NH}), 7.78\left(\mathrm{~d},{ }^{3} \mathrm{~J}_{\mathrm{HH}}=8 \mathrm{~Hz}, 2 \mathrm{H}\right.$, aryl $\left.\mathrm{CH}\right), 7.34-7.31(\mathrm{~m}, 2 \mathrm{H}$, aryl $\mathrm{CH})$, 7.06-7.02 (m, $4 \mathrm{H}$, aryl $\mathrm{C} \underline{H}), 4.00\left(\mathrm{~s}, 6 \mathrm{H}, \mathrm{OC}_{3}\right) .{ }^{13} \mathrm{C}\left\{{ }^{1} \mathrm{H}\right\}$ NMR $(150.8$ $\left.\mathrm{MHz}, \mathrm{CDCl}_{3}\right): 152.5,136.1,130.0,121.4,116.5,116.5,116.1,112.0$, 56.1. FTIR (KBr): $3074(\mathrm{~m}), 3027(\mathrm{~m}), 2970(\mathrm{~m}), 2944(\mathrm{~m}), 2840(\mathrm{~m})$,

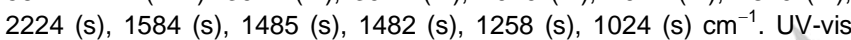
(toluene): $\lambda_{\max } 448 \mathrm{~nm}\left(\varepsilon=19,700 \mathrm{M}^{-1} \mathrm{~cm}^{-1}\right)$. $\mathrm{MS}(\mathrm{El}=+$ ve mode): exact mass calculated for $\left[\mathrm{C}_{16} \mathrm{H}_{15} \mathrm{~N}_{5} \mathrm{O}_{2}\right]^{+}: 309.1226$; exact mass found: 309.1238; difference: +3.9 ppm.

Formazan $4 \mathrm{~b}\left(\mathbf{A r}_{1}=\mathbf{A r}_{5}=\boldsymbol{m}\right.$-anisole, $\left.\mathbf{R}_{3}=\mathbf{C N}\right)$. From $3.41 \mathrm{~g}(27.7$ $\mathrm{mmol}$ ) of $m$-anisidine. Yield $=0.751 \mathrm{~g}, 18 \%$ of a dark red microcrystalline solid. M.p. $132-134{ }^{\circ} \mathrm{C}$. ${ }^{1} \mathrm{H}$ NMR $\left(599.5 \mathrm{MHz}, \mathrm{CDCl}_{3}\right)$ : Open Isomer (major, $75 \%) \delta 12.89(\mathrm{~s}, 1 \mathrm{H}, \mathrm{NH}), 7.37\left(\mathrm{t},{ }^{3} \mathrm{~J}_{\mathrm{HH}}=8 \mathrm{~Hz}, 2 \mathrm{H}\right.$, aryl $\mathrm{CH}$ ), 7.22-7.21 (m, 2H, aryl $\mathrm{CH}), 7.19-7.17(\mathrm{~m}, 2 \mathrm{H}$, aryl $\mathrm{CH}), 6.92\left(\mathrm{dd},{ }^{3} \mathrm{JHH}_{\mathrm{HH}}=\right.$ $8 \mathrm{~Hz},{ }^{4} \mathrm{JHH}_{\mathrm{HH}}=3 \mathrm{~Hz}, 2 \mathrm{H}$, aryl $\mathrm{CH}$ ), $3.89\left(\mathrm{~s}, 6 \mathrm{H}, \mathrm{OC} \mathrm{H}_{3}\right)$; Linear Isomer (minor $25 \%) \delta 9.14(\mathrm{~s}, 1 \mathrm{H}, \mathrm{NH}), 7.53\left(\mathrm{~d},{ }^{3} \mathrm{JHH}_{\mathrm{HH}}=8 \mathrm{~Hz}, 1 \mathrm{H}\right.$, aryl $\left.\mathrm{C} \underline{H}\right), 7.43-7.40(\mathrm{~m}$ $3 \mathrm{H}$, aryl $\mathrm{C} \underline{H}), 7.33-7.30(\mathrm{~m}, 1 \mathrm{H}$, aryl $\mathrm{C} \underline{H}), 7.07-7.06(\mathrm{~m}, 1 \mathrm{H}$, aryl $\mathrm{C} \underline{H})$, $7.02(\mathrm{~m}, 1 \mathrm{H}$, aryl $\mathrm{CH}), 6.74-6.73(\mathrm{~m}, 1 \mathrm{H}$, aryl $\mathrm{CH}), 3.89\left(\mathrm{~s}, 3 \mathrm{H}, \mathrm{OC}_{3}\right)$, $3.88\left(\mathrm{~s}, 3 \mathrm{H}, \mathrm{OCH}_{3}\right) .{ }^{13} \mathrm{C}\left\{{ }^{1} \mathrm{H}\right\} \mathrm{NMR}\left(150.8 \mathrm{MHz}, \mathrm{CDCl}_{3}\right): \delta 161.0,160.8$ $160.4,153.2,147.5,142.0,130.5,130.3,130.3,129.9,125.1,119.2$, $117.7,115.7,114.4,113.0,111.2,108.0,107.9,105.6,103.5,100.9$, $55.6(\mathrm{br})$. FTIR $(\mathrm{KBr}): 3276(\mathrm{~m}), 3086(\mathrm{~m}), 3008(\mathrm{~m}), 2960(\mathrm{~m}), 2839(\mathrm{~m})$ 2227 (s), 1609 (s), 1535 (s), 1496 (s), $1412(\mathrm{~m}), 1240$ (s), $1150(\mathrm{~m}), 1044$ (s) $\mathrm{cm}^{-1}$. UV-vis (toluene): $\lambda_{\max } 432 \mathrm{~nm}\left(\varepsilon=20,150 \mathrm{M}^{-1} \mathrm{~cm}^{-1}\right)$. MS $(\mathrm{El}=$ +ve mode): exact mass calculated for $\left[\mathrm{C}_{16} \mathrm{H}_{15} \mathrm{~N}_{5} \mathrm{O}_{2}\right]^{+}$: 309.1226; exact mass found: 309.1221 ; difference: $-1.6 \mathrm{ppm}$.
Formazan $\mathbf{4 d}\left(\mathbf{A r}_{1}=\mathbf{A r}_{5}=\right.$ o-ethylbenzene, $\left.\mathbf{R}_{3}=\mathbf{C N}\right)$. From $2.96 \mathrm{~g}(24.4$ $\mathrm{mmol}$ ) of 2-ethylaniline. Yield $=0.322 \mathrm{~g}, 9 \%$ of a dark red powder. M.p. 89-91 ${ }^{\circ} \mathrm{C}$. ${ }^{1} \mathrm{H}$ NMR $\left(599.5 \mathrm{MHz}, \mathrm{CDCl}_{3}\right)$ : Open Isomer (major, $\left.81 \%\right) \delta$ $11.75(\mathrm{~s}, 1 \mathrm{H}, \mathrm{N} \underline{H}), 7.67-7.65(\mathrm{~m}, 2 \mathrm{H}$, aryl $\mathrm{CH}), 7.34-7.31(\mathrm{~m}, 6 \mathrm{H}$, aryl $\mathrm{CH}$ ), $2.97\left(\mathrm{q},{ }^{3} \mathrm{JHH}_{\mathrm{HH}}=8 \mathrm{~Hz}, 4 \mathrm{H}, \mathrm{C}_{2} \mathrm{CH}_{3}\right), 1.35\left(\mathrm{~m}, 6 \mathrm{H}, \mathrm{CH}_{2} \mathrm{C}_{3}\right)$; Linear Isomer (minor, 29\%) $\delta 9.17(\mathrm{~s}, 1 \mathrm{H}, \mathrm{N} \underline{H}), 7.77\left(\mathrm{~d},{ }^{3} \mathrm{~J}_{\mathrm{HH}}=8 \mathrm{~Hz}, 1 \mathrm{H}\right.$, aryl $\mathrm{C} \underline{H}), 7.72(\mathrm{~m}, 1 \mathrm{H}$, aryl $\mathrm{C} \underline{H}), 7.44(\mathrm{~m}, 2 \mathrm{H}, \operatorname{aryl} \underline{\mathrm{C}}), 7.40(\mathrm{~m}, 2 \mathrm{H}$, aryl $\underline{\mathrm{C}} \underline{\mathrm{H}})$, 7.30-7.28 (m, 1H, aryl $\underline{\mathrm{CH}}), 7.15(\mathrm{~m}, 1 \mathrm{H}, \mathrm{C} \underline{H}), 3.18\left(\mathrm{q},{ }^{3} \mathrm{JH}=8 \mathrm{~Hz}, 4 \mathrm{H}\right.$, $\mathrm{C}_{2} \mathrm{CH}_{3}$ ), 2.80 (q, $\left.{ }^{3} \mathrm{JHH}_{\mathrm{HH}}=8 \mathrm{~Hz}, 2 \mathrm{H}, \mathrm{C}_{2} \mathrm{CH}_{3}\right), 1.39\left(\mathrm{~m}, 6 \mathrm{H}, \mathrm{CH}_{2} \mathrm{CH}_{3}\right)$. ${ }^{13} \mathrm{C}\left\{{ }^{1} \mathrm{H}\right\}$ NMR $\left(150.8 \mathrm{MHz}, \mathrm{CDCl}_{3}\right): \delta 149.3,145.3,144.2,138.1,137.8$ $132.3,131.9,130.0,129.6,129.5,129.1,129.0,127.6,127.4,127.2$, $126.5,124.8,115.6,115.5,115.4,113.3,108.0,24.7,24.2,23.5,16.3$ 15.0, 13.8. FTIR (KBr): $3338(\mathrm{~m}), 3077(\mathrm{~m}), 2973(\mathrm{~m}), 2936(\mathrm{~m}), 2878$ $(\mathrm{m}), 2227(\mathrm{~m}), 1589(\mathrm{~m}), 1529(\mathrm{~s}), 1457(\mathrm{~m}), 1276(\mathrm{~m}), 1201(\mathrm{~m}), 1157$ (m), $1060(\mathrm{w}) \mathrm{cm}^{-1}$. UV-vis (toluene): $\lambda_{\max } 419 \mathrm{~nm}\left(\varepsilon=25,500 \mathrm{M}^{-1} \mathrm{~cm}^{-1}\right)$. MS (El = +ve mode): exact mass calculated for $\left[\mathrm{C}_{18} \mathrm{H}_{19} \mathrm{~N}_{5}\right]^{+}: 305.1640$; exact mass found: 305.1639 ; difference: $-0.3 \mathrm{ppm}$.

Representative Procedure for the Preparation of Formazans 5a and $5 b$

Formazan 5a $\left(\mathrm{Ar}_{1}=\mathrm{Ar}_{5}=\right.$ o-anisole, $\left.\mathbf{R}_{3}=\mathrm{NO}_{2}\right)$. The following procedure was adapted from a protocol developed by von Eschwege and co-workers. ${ }^{[19 \mathrm{~b}]} \mathrm{In}$ air, o-anisidine $(3.63 \mathrm{~g}, 29.5 \mathrm{mmol})$ was added to deionized water $(28 \mathrm{~mL})$ containing concentrated hydrochloric acid $(16.0$ $\mathrm{mL}, 192 \mathrm{mmol}$ ). The mixture was cooled to $-10{ }^{\circ} \mathrm{C}$ in an acetone/ice bath and stirred for $1 \mathrm{~h}$. In a separate flask, sodium nitrite $(3.22 \mathrm{~g}, 46.7 \mathrm{mmol})$ was dissolved in deionized water $(9.20 \mathrm{~mL})$ and cooled to $-10{ }^{\circ} \mathrm{C}$ in an acetone/ice bath for $30 \mathrm{~min}$. The sodium nitrite solution was added to the $o$-anisidine mixture dropwise over the course of $30 \mathrm{~min}$. The resulting yellow-brown diazonium salt solution was then added to a flask containing sodium acetate $(28.5 \mathrm{~g}, 347 \mathrm{mmol})$, glacial acetic acid $(29.0$ $\mathrm{mL}$ ) and deionized water $(14 \mathrm{~mL})$ and stirred at room temperature for 5 min. Nitromethane $(8.98 \mathrm{~g}, 7.97 \mathrm{~mL}, 147 \mathrm{mmol})$ was then added and the solution was stirred for $1 \mathrm{~h}$ before deionized water $(1.60 \mathrm{~L})$ was added. The solution was stirred for an additional $30 \mathrm{~min}$ and vacuum filtered to afford a red solid. The filtrate was extracted into dichloromethane $(3 \times$ $250 \mathrm{~mL})$, washed with deionized water $(4 \times 200 \mathrm{~mL})$, dried over $\mathrm{MgSO}_{4}$, gravity filtered and concentrated in vacuo to afford a dark red solid. The crude solids were combined and purified by flash column chromatography (dichloromethane, neutral alumina) to afford formazan 5a as a dark red microcrystalline solid. Yield $=4.01 \mathrm{~g}, 82 \%$. M.p. 176-178 ${ }^{\circ} \mathrm{C} .{ }^{1} \mathrm{H}$ NMR $\left(599.5 \mathrm{MHz}, \mathrm{CDCl}_{3}\right): \delta 14.87(\mathrm{~s}, 1 \mathrm{H}, \mathrm{NH})$, 7.97-7.95 (m, 2H, aryl $\mathrm{C} \underline{H}), 7.38-7.35(\mathrm{~m}, 2 \mathrm{H}$, aryl $\mathrm{C} \underline{H}), 7.08-7.05(\mathrm{~m}$, $2 \mathrm{H}$, aryl $\mathrm{C} \underline{H}), 7.04-7.03(\mathrm{~m}, 2 \mathrm{H}$, aryl $\mathrm{C} \underline{H}), 4.02\left(\mathrm{~s}, 6 \mathrm{H}, \mathrm{OC} \underline{H}_{3}\right) .{ }^{13} \mathrm{C}\left\{{ }^{1} \mathrm{H}\right\}$ NMR $\left(150.8 \mathrm{MHz}, \mathrm{CDCl}_{3}\right): \delta 153.0,136.2,130.8,121.6,117.0,112.0$ 56.1. FTIR (KBr): $3057(\mathrm{~m}), 2990(\mathrm{~m}), 1660(\mathrm{~m}), 1578(\mathrm{~s}), 1423(\mathrm{~m})$, $1267(\mathrm{~m}), 897(\mathrm{~m}) \mathrm{cm}^{-1}$. UV-vis (toluene): $\lambda_{\max } 472 \mathrm{~nm}\left(\varepsilon=8,000 \mathrm{M}^{-1}\right.$ $\left.\mathrm{cm}^{-1}\right)$. MS $\left(\mathrm{EI}=+\right.$ ve mode): exact mass calculated for $\left[\mathrm{C}_{15} \mathrm{H}_{15} \mathrm{~N}_{5} \mathrm{O}_{4}\right]^{+}$. 329.1124; exact mass found: 329.1121 ; difference: $-0.9 \mathrm{ppm}$.

Formazan $5 \mathbf{b}\left(\mathbf{A r}_{1}=\mathbf{A r}_{5}=\boldsymbol{m}\right.$-anisole, $\left.\mathbf{R}_{3}=\mathbf{N O}_{2}\right)$. From $2.19 \mathrm{~g}(17.8$ $\mathrm{mmol}$ ) of $m$-anisidine. Yield $=1.77 \mathrm{~g}, 60 \%$ of dark red microcrystalline solid. M.p. $134-136{ }^{\circ} \mathrm{C} .{ }^{1} \mathrm{H}$ NMR $\left(599.5 \mathrm{MHz}, \mathrm{CDCl}_{3}\right): \delta 15.08(\mathrm{~s}, 1 \mathrm{H}$ $\mathrm{NH}), 7.35\left(\mathrm{t},{ }^{3} \mathrm{JHH}_{\mathrm{H}}=8 \mathrm{~Hz}, 2 \mathrm{H}\right.$, aryl $\left.\mathrm{CH}\right), 7.24-7.23(\mathrm{~m}, 2 \mathrm{H}$, aryl $\mathrm{CH})$, 7.21-7.19 (m, $2 \mathrm{H}$, aryl $\mathrm{CH}), 6.92\left(\mathrm{dd},{ }^{3} \mathrm{JHH}_{\mathrm{HH}}=8 \mathrm{~Hz},{ }^{4} \mathrm{~J}_{\mathrm{HH}}=2 \mathrm{~Hz} 2 \mathrm{H}\right.$, aryl $\mathrm{C} \underline{H}), 3.85\left(\mathrm{~s}, 6 \mathrm{H}, \mathrm{OC} \underline{H}_{3}\right) .{ }^{13} \mathrm{C}\left\{{ }^{1} \mathrm{H}\right\}$ NMR $\left(150.8 \mathrm{MHz}, \mathrm{CDCl}_{3}\right): \delta 160.8$, 147.2, 130.3, 116.4, 113.8, 103.3, 55.5. FTIR (KBr): $3058(\mathrm{~m}), 3018(\mathrm{~m})$ $2973(\mathrm{~m}), 2858(\mathrm{~m}), 1661(\mathrm{~m}), 1610(\mathrm{~s}) 1552(\mathrm{~m}), 1493(\mathrm{w}), 1434(\mathrm{w})$, $1360(w), 1267(\mathrm{~s}), 1143(\mathrm{w}), 1045(\mathrm{w}), 896(\mathrm{w}), 826(\mathrm{~s}) \mathrm{cm}^{-1}$. UV-vis (toluene): $\lambda_{\max } 466 \mathrm{~nm}\left(\varepsilon=21,200 \mathrm{M}^{-1} \mathrm{~cm}^{-1}\right)$. MS $(\mathrm{El}=+\mathrm{ve}$ mode): exact mass calculated for $\left[\mathrm{C}_{15} \mathrm{H}_{15} \mathrm{~N}_{5} \mathrm{O}_{4}\right]^{+}$: 329.1124 ; exact mass found: 329.1118; difference: $-1.8 \mathrm{ppm}$ 
Preparation of Formazan 5c $\left(\mathbf{A r}_{1}=\mathbf{A r}_{5}=p\right.$-anisole, $\left.\mathbf{R}_{3}=\mathbf{N O}_{2}\right)$. In air nitromethane $(1.23 \mathrm{~g}, 1.08 \mathrm{~mL}, 20.0 \mathrm{mmol})$ was combined with deionized water $(150 \mathrm{~mL})$, and sodium hydroxide $(1.76 \mathrm{~g}, 44.0 \mathrm{mmol})$ before the mixture was cooled to $0^{\circ} \mathrm{C}$ in an ice bath. In a separate flask, $p$-anisidine $(5.00 \mathrm{~g}, 41.0 \mathrm{mmol})$ and concentrated hydrochloric acid $(11.1 \mathrm{~mL}, 133$ $\mathrm{mmol}$ ) were mixed with deionized water $(15 \mathrm{~mL})$ and cooled to $0{ }^{\circ} \mathrm{C}$ in an ice bath. A cooled solution $\left(0^{\circ} \mathrm{C}\right)$ of sodium nitrite $(3.35 \mathrm{~g}, 49.0 \mathrm{mmol})$ in deionized water $(10 \mathrm{~mL})$ was added slowly to the amine solution. This mixture was left to stir at $0{ }^{\circ} \mathrm{C}$ for $30 \mathrm{~min}$, at which time the dark yellow diazonium salt solution was added dropwise to the nitromethane solution described above over a $10 \mathrm{~min}$ period. The resulting mixture was left to warm slowly with stirring for $18 \mathrm{~h}$, during which time a dark red precipitate had formed. The dark red solid was isolated by vacuum filtration and purified by flash column chromatography (dichloromethane, neutral alumina) to afford formazan $\mathbf{5 c}$ as a dark red microcrystalline solid. Yield $=6.59$ g, $55 \%$. M.p. $162-164{ }^{\circ} \mathrm{C} .{ }^{1} \mathrm{H}$ NMR $\left(599.5 \mathrm{MHz}\right.$, DMSO- $\left.d_{6}\right): \delta$ $14.61(\mathrm{~s}, 1 \mathrm{H}, \mathrm{N} \underline{H}), 7.86\left(\mathrm{~d},{ }^{3} \mathrm{~J}_{\mathrm{HH}}=8 \mathrm{~Hz}, 4 \mathrm{H}, \operatorname{aryl~} \underline{\mathrm{H}}\right), 7.11\left(\mathrm{~d},{ }^{3} \mathrm{~J}_{\mathrm{HH}}=8 \mathrm{~Hz}\right.$ $4 \mathrm{H}$, aryl $\mathrm{CH}), 3.85\left(\mathrm{~s}, 6 \mathrm{H}, \mathrm{OC} \underline{H}_{3}\right) \cdot{ }^{13} \mathrm{C}\left\{{ }^{1} \mathrm{H}\right\}$ NMR $\left(150.8 \mathrm{MHz}\right.$, DMSO-d $\left.d_{6}\right): \delta$ 160.5, 140.1, 121.8, 114.9, 55.7. FTIR (KBr): $3061(\mathrm{~m}), 3018(\mathrm{~m}), 2995$ $(\mathrm{m}), 1659(\mathrm{~m}), 1574(\mathrm{w}), 1428(\mathrm{~m}), 1348(\mathrm{w}), 1268(\mathrm{~s}), 1159(\mathrm{w}), 899(\mathrm{~m})$, $745(\mathrm{~m}) \mathrm{cm}^{-1}$. UV-vis (toluene): $\lambda_{\max } 504 \mathrm{~nm}\left(\varepsilon=18,400 \mathrm{M}^{-1} \mathrm{~cm}^{-1}\right)$. MS (El, +ve mode): exact mass calculated for $\left[\mathrm{C}_{15} \mathrm{H}_{15} \mathrm{~N}_{5} \mathrm{O}_{4}\right]^{+}: 329.1124$; exact mass found: 329.1123 ; difference: $-0.3 \mathrm{ppm}$.

\section{Representative Procedure for Preparation of Formazans 6a-c}

Formazan $6 \mathbf{a}\left(\mathbf{A r}_{1}=\mathbf{A} \mathbf{r}_{5}=\right.$ o-anisole, $\left.\mathbf{R}_{3}=\mathbf{P h}\right)$. In air, phenylpyruvic acid $(1.0 \mathrm{~g}, 6.1 \mathrm{mmol})$ and sodium hydroxide $(1.83 \mathrm{~g}, 45.7 \mathrm{mmol})$ were combined with deionized water $(150 \mathrm{~mL})$ and cooled to $0{ }^{\circ} \mathrm{C}$ in an ice bath for $30 \mathrm{~min}$. In a separate flask, 0 -anisidine $(1.50 \mathrm{~g}, 12.2 \mathrm{mmol})$ and concentrated hydrochloric acid $(3.5 \mathrm{~mL}, 42 \mathrm{mmol})$ were mixed in deionized water $(10 \mathrm{~mL})$, and cooled to $0{ }^{\circ} \mathrm{C}$ in an ice bath for $10 \mathrm{~min}$. A cooled solution $\left(0^{\circ} \mathrm{C}\right)$ of sodium nitrite $(0.97 \mathrm{~g}, 14.0 \mathrm{mmol})$ in deionized water $(5 \mathrm{~mL})$ was added slowly to the amine solution over a $10 \mathrm{~min}$ period. This yellow mixture was left to stir at $0{ }^{\circ} \mathrm{C}$ for $30 \mathrm{~min}$, at which time it was added dropwise to the phenylpyruvic acid reaction mixture described above over a 10 min period. The resulting solution was left to warm slowly with stirring for $18 \mathrm{~h}$, at which time a purple precipitate had formed. The purple solid was isolated by filtration and purified by flash column chromatography (dichloromethane, neutral alumina) to afford formazan $6 \mathbf{a}$ as a purple microcrystalline solid. Yield $=1.98 \mathrm{~g}, 90 \%$. M.p. 120-122 ${ }^{\circ} \mathrm{C} .{ }^{1} \mathrm{H}$ NMR $\left(599.5 \mathrm{MHz}, \mathrm{CDCl}_{3}\right): \delta 15.01$ (s, $1 \mathrm{H}, \mathrm{N} \underline{\mathrm{H}}$ ), 8.24-8.23 (m, $2 \mathrm{H}$, aryl $\mathrm{C} \underline{H}), 7.98-7.97(\mathrm{~m}, 2 \mathrm{H}$, aryl $\mathrm{C} \underline{\mathrm{H}}), 7.49-7.46(\mathrm{~m}$, $2 \mathrm{H}$, aryl $\mathrm{C} \underline{H}), 7.38-7.36(\mathrm{~m}, 1 \mathrm{H}$, aryl $\mathrm{C} \underline{H}), 7.28-7.25(\mathrm{~m}, 2 \mathrm{H}$, aryl $\mathrm{C} \underline{H})$, 7.10-7.07 $(\mathrm{m}, 2 \mathrm{H}$, aryl $\mathrm{CH}), 7.04-7.02(\mathrm{~m}, 2 \mathrm{H}$, aryl $\mathrm{CH}), 4.02(\mathrm{~s}, 6 \mathrm{H}$, $\left.\mathrm{OC}_{3}\right) .{ }^{13} \mathrm{C}\left\{{ }^{1} \mathrm{H}\right\} \mathrm{NMR}\left(100.6 \mathrm{MHz}, \mathrm{CDCl}_{3}\right): \delta 152.0,142.2,138.0,137.9$, 128.3, 128.0, 127.3, 125.8, 121.3, 115.7, 111.7, 56.0. FT-IR (KBr): 3076 (m), $3008(\mathrm{~m}), 2915(\mathrm{~m}), 1659(\mathrm{~m}), 1267(\mathrm{~m}), 1106(\mathrm{~s}), 752(\mathrm{~m}) \mathrm{cm}^{-1}$. UV-vis (toluene): $\lambda_{\max }=507 \mathrm{~nm}\left(\varepsilon=22,900 \mathrm{M}^{-1} \mathrm{~cm}^{-1}\right)$. Mass Spec. (EI, +ve mode): exact mass calculated for $\left[\mathrm{C}_{21} \mathrm{H}_{20} \mathrm{~N}_{4} \mathrm{O}_{2}\right]^{+}$: 360.1586; exact mass found: 360.1580 ; difference: $-1.7 \mathrm{ppm}$.

Formazan $\mathbf{6 b}\left(\mathbf{A r}_{1}=\mathbf{A r}_{5}=\boldsymbol{m}\right.$-anisole, $\left.\mathbf{R}_{3}=\mathbf{P h}\right)$. From $1.50 \mathrm{~g}(12.2$ $\mathrm{mmol}$ ) of $m$-anisidine. Yield $=1.38 \mathrm{~g}, 63 \%$ as a dark red solid. M.p. 99 $101{ }^{\circ} \mathrm{C} .{ }^{1} \mathrm{H}$ NMR $\left(599.5 \mathrm{MHz}, \mathrm{CDCl}_{3}\right): \delta 15.35(\mathrm{~s}, 1 \mathrm{H}, \mathrm{NH}), 8.15-8.14(\mathrm{~m}$, $2 \mathrm{H}$, aryl $\mathrm{CH}), 7.48-7.46(\mathrm{~m}, 2 \mathrm{H}$, aryl $\mathrm{CH}), 7.39-7.36(\mathrm{~m}, 3 \mathrm{H}$, aryl $\mathrm{CH})$, $7.31(\mathrm{~s}, 2 \mathrm{H}$, aryl $\mathrm{C} \underline{H}), 7.24-7.23(\mathrm{~m}, 2 \mathrm{H}$, aryl $\mathrm{C} \underline{H}), 6.87-6.85(\mathrm{~m}, 2 \mathrm{H}$, aryl $\mathrm{CH}), 3.91\left(\mathrm{~s}, 6 \mathrm{H}, \mathrm{OCH}_{3}\right) .{ }^{13} \mathrm{C}\left\{{ }^{1} \mathrm{H}\right\}$ NMR $\left(100.6 \mathrm{MHz} \mathrm{CDCl}_{3}\right)$ : $\delta 160.7$, $149.1,141.0,137.3,130.0,128.4,127.6,125.8,113.4,112.6,102.9$, 55.4. FTIR (KBr): $3057(\mathrm{~m}), 2991(\mathrm{~m}), 1660(\mathrm{~m}), 1643(\mathrm{~m}), 1426(\mathrm{~m})$, $1268(\mathrm{~s}), 1103(\mathrm{~s}), 898(\mathrm{~m}), 745(\mathrm{~m}) \mathrm{cm}^{-1}$. UV-vis (toluene): $\lambda_{\max }=496$ $\mathrm{nm}\left(\varepsilon=21,600 \mathrm{M}^{-1} \mathrm{~cm}^{-1}\right)$. Mass Spec. (EI, +ve mode): exact mass calculated for $\left[\mathrm{C}_{21} \mathrm{H}_{20} \mathrm{~N}_{4} \mathrm{O}_{2}\right]^{+}: 360.1586$; exact mass found: 360.1584 ; difference: $-0.6 \mathrm{ppm}$.
Formazan $6 \mathrm{c}\left(\mathbf{A r}_{1}=\mathbf{A r}_{5}=p\right.$-anisole, $\left.\mathbf{R}_{3}=\mathbf{P h}\right)$. From $1.48 \mathrm{~g}(12.0 \mathrm{mmol})$ of $p$-anisidine. Yield $=1.69 \mathrm{~g}, 82 \%$ as a dark red solid. M.p. $122-124{ }^{\circ} \mathrm{C}$. ${ }^{1} \mathrm{H}$ NMR $\left(599.5 \mathrm{MHz}, \mathrm{CDCl}_{3}\right): \delta 15.56(\mathrm{~s}, 1 \mathrm{H}, \mathrm{N} \underline{H}), 8.13\left(\mathrm{~d},{ }^{3} \mathrm{~J}_{\mathrm{HH}}=7 \mathrm{~Hz}\right.$, $2 \mathrm{H}$, aryl $\underline{\mathrm{C}}), 7.65\left(\mathrm{~d},{ }^{3} \mathrm{JHH}_{\mathrm{HH}}=9 \mathrm{~Hz}, 4 \mathrm{H}\right.$, aryl $\left.\mathrm{CH}\right), 7.45-7.43(\mathrm{~m}, 2 \mathrm{H}$, aryl $\mathrm{C} \underline{H}), 7.34\left(\mathrm{t},{ }^{3} \mathrm{JHH}_{\mathrm{HH}}=8 \mathrm{~Hz}, 1 \mathrm{H}\right.$, aryl $\left.\underline{\mathrm{CH}}\right), 6.99\left(\mathrm{~d},{ }^{3} \mathrm{~J}_{\mathrm{HH}}=9 \mathrm{~Hz}, 4 \mathrm{H}\right.$, aryl $\left.\mathrm{C} \underline{H}\right)$, $3.88\left(\mathrm{~s}, 6 \mathrm{H}, \mathrm{OCH}_{3}\right) .{ }^{13} \mathrm{C}\left\{{ }^{1} \mathrm{H}\right\}$ NMR $\left(100.6 \mathrm{MHz}, \mathrm{CDCl}_{3}\right): \delta 159.2,142.0$ 140.6, 137.8, 128.3, 127.2, 125.6, 120.0, 114.7, 55.6. FTIR (KBr): 3263 (br, s), $2984(\mathrm{~m}), 2884(\mathrm{w}), 2794$ (s), 1594 (s), $1573(\mathrm{~m}), 1507$ (s), 1495 (s), $1226(\mathrm{~s}), 1176(\mathrm{~m}) \mathrm{cm}^{-1}$. UV-vis (toluene): $\lambda_{\max }=530 \mathrm{~nm}(\varepsilon=23,400$ $\mathrm{M}^{-1} \mathrm{~cm}^{-1}$ ). Mass Spec. (El, +ve mode): exact mass calculated for $\left[\mathrm{C}_{21} \mathrm{H}_{20} \mathrm{~N}_{4} \mathrm{O}_{2}\right]^{+}: 360.1586$; exact mass found: 360.1581 ; difference: -1.4 ppm.

Representative Procedure for the Preparation of Formazanate $\mathrm{BF}_{2}$ Complexes $7 a$ and $7 d$

Formazanate $\mathrm{BF}_{2}$ Complex $7 \mathrm{a}\left(\mathrm{Ar}_{1}=\mathrm{Ar}_{5}=\right.$ o-anisole, $\left.\mathrm{R}_{3}=\mathrm{CN}\right)$. Formazan $4 \mathbf{a}(0.500 \mathrm{~g}, 1.61 \mathrm{mmol})$ was dissolved in toluene $(250 \mathrm{~mL})$ before triethylamine $(1.45 \mathrm{~g}, 2.00 \mathrm{~mL}, 14.2 \mathrm{mmol})$ was added and the solution stirred for $30 \mathrm{~min}$. Boron trifluoride diethyl etherate $(3.45 \mathrm{~g}, 3.00$ $\mathrm{mL}, 24.3 \mathrm{mmol}$ ) was then added and the solution heated to $105^{\circ} \mathrm{C}$ for 36 h. During this time, the solution gradually changed color from dark red to red-orange. The solution was cooled to $20{ }^{\circ} \mathrm{C}$ and deionized water (25 $\mathrm{mL}$ ) was added to quench any remaining reactive species. The mixture was then washed with deionized water $(3 \times 50 \mathrm{~mL})$, dried over $\mathrm{MgSO}_{4}$, gravity filtered, and concentrated in vacuo to afford $7 \mathrm{a}$ as a red-orange solid. The crude solid was purified via flash column chromatography (dichloromethane, neutral alumina) to afford $7 \mathbf{a}$ as a bright orange powder. This compound hydrolyzes slowly. Analyses were performed using dry solvents. Yield $=0.353 \mathrm{~g}, 61 \%$. M.p. $134-136{ }^{\circ} \mathrm{C} .{ }^{1} \mathrm{H}$ NMR $\left(599.5 \mathrm{MHz}\right.$, dry $\left.\mathrm{CDCl}_{3}\right): \delta$ 7.46-7.43 (m, $2 \mathrm{H}$, aryl CH$), 7.30-7.28(\mathrm{~m}, 2 \mathrm{H}$ aryl $\mathrm{CH}), 7.05-7.01(\mathrm{~m}, 4 \mathrm{H}$, aryl $\mathrm{C} \underline{H}), 3.91\left(\mathrm{~s}, 6 \mathrm{H}, \mathrm{OC}_{3}\right) .{ }^{13} \mathrm{C}\left\{{ }^{1} \mathrm{H}\right\} \mathrm{NMR}$ $\left(150.8 \mathrm{MHz}, \mathrm{CDCl}_{3}\right): \delta 154.8,132.5,132.4,127.2,120.8,113.8,112.8$ 56.4. ${ }^{11} \mathrm{~B}$ NMR $\left(128.3 \mathrm{MHz}, \mathrm{CDCl}_{3}\right): \delta-1.9\left(\mathrm{t},{ }^{1} \mathrm{~J}_{\mathrm{BF}}=20 \mathrm{~Hz}\right) .{ }^{19} \mathrm{~F} \mathrm{NMR}$ $\left(376.1 \mathrm{MHz}, \mathrm{CDCl}_{3}\right): \delta-154.3\left(\mathrm{q},{ }^{1} J_{\mathrm{FB}}=19 \mathrm{~Hz}\right)$. FTIR $(\mathrm{KBr}): 3072(\mathrm{~m})$ $3017(\mathrm{~m}), 2960(\mathrm{~m}), 2853(\mathrm{~m}), 2237(\mathrm{~s}), 1605(\mathrm{~s}), 1488(\mathrm{~s}), 1340(\mathrm{~s})$, 1260 (s), 1195 (s), 1164 (s), 1030 (s) cm $\mathrm{cm}^{-1}$. UV-vis (toluene): $\lambda_{\max } 467 \mathrm{~nm}$ $\left(\varepsilon=16,000 \mathrm{M}^{-1} \mathrm{~cm}^{-1}\right)$. MS $(\mathrm{El}=+$ ve mode $)$ : exact mass calculated for $\left[\mathrm{C}_{16} \mathrm{H}_{14} \mathrm{BF}_{2} \mathrm{~N}_{5} \mathrm{O}_{2}\right]^{+}:$357.1209; exact mass found: 357.1212; difference: $+0.8 \mathrm{ppm}$

Formazanate $\mathrm{BF}_{2}$ Complex $\mathbf{7 d}\left(\mathrm{Ar}_{1}=\mathrm{Ar}_{5}=\right.$ o-ethylbenzene, $\left.\mathbf{R}_{3}=\mathrm{CN}\right)$. From $0.366 \mathrm{~g}(1.20 \mathrm{mmol})$ of formazan $4 \mathrm{~d}$. Yield $=0.095 \mathrm{~g}, 22 \%$ of dark orange oil. ${ }^{1} \mathrm{H}$ NMR $\left(599.5 \mathrm{MHz}, \mathrm{CDCl}_{3}\right): \delta 7.47-7.45(\mathrm{~m}, 2 \mathrm{H}$, aryl $\mathrm{C} \underline{H})$, 7.42-7.39 (m, 4H, aryl $\mathrm{CH}), 7.34-7.31(\mathrm{~m}, 2 \mathrm{H}$, aryl $\mathrm{CH}), 2.65\left(\mathrm{q},{ }^{3} \mathrm{~J}_{\mathrm{HH}}=8\right.$ $\left.\mathrm{Hz}, 4 \mathrm{H}, \mathrm{C}_{2} \mathrm{CH}_{3}\right), 1.24\left(\mathrm{t},{ }^{3} \mathrm{~J}_{\mathrm{HH}}=7 \mathrm{~Hz}, 6 \mathrm{H}, \mathrm{CH}_{2} \mathrm{CH}_{3}\right) .{ }^{13} \mathrm{C}\left\{{ }^{1} \mathrm{H}\right\} \mathrm{NMR}(150.8$ $\left.\mathrm{MHz}, \mathrm{CDCl}_{3}\right): \delta 140.9,139.7,131.0,130.5,126.6,126.3,113.4,24.3$ 14.9. ${ }^{11} \mathrm{~B}$ NMR $\left(128.3 \mathrm{MHz}, \mathrm{CDCl}_{3}\right): \delta-1.9\left(\mathrm{t},{ }^{1} \mathrm{~J}_{\mathrm{BF}}=24 \mathrm{~Hz}\right) .{ }^{19} \mathrm{~F}(376.1$ $\left.\mathrm{MHz}, \mathrm{CDCl}_{3}\right): \delta-146.9\left(\mathrm{q},{ }^{1} \mathrm{~J}_{\mathrm{FB}}=24 \mathrm{~Hz}\right)$. FTIR $(\mathrm{KBr}): 3077(\mathrm{~m}), 2975(\mathrm{~s})$, $2938(\mathrm{~s}), 2879(\mathrm{~m}), 2247(\mathrm{~m}), 1453(\mathrm{~s}), 1336(\mathrm{~s}), 1217(\mathrm{~s}), 1084(\mathrm{~s}), 1025$ (s), 970 (s) $\mathrm{cm}^{-1}$. UV-vis (toluene): $\lambda_{\max } 436 \mathrm{~nm}\left(\varepsilon=14,000 \mathrm{M}^{-1} \mathrm{~cm}^{-1}\right)$. MS $\left(\mathrm{El}=+\right.$ ve mode): exact mass calculated for $\left[\mathrm{C}_{18} \mathrm{H}_{18} \mathrm{BF}_{2} \mathrm{~N}_{5}\right]^{+}$: 353.1623; exact mass found: 353.1626 ; difference: +0.8 ppm.

Representative Procedure for the Preparation of Formazanate $\mathrm{BF}_{2}$ Complexes $7 b, 8 b, c$, and $9 a-c$

Formazanate $\mathrm{BF}_{2}$ Complex $7 \mathrm{~b}\left(\mathrm{Ar}_{1}=\mathrm{Ar}_{5}=m\right.$-anisole, $\left.\mathrm{R}_{3}=\mathrm{CN}\right)$. Formazan $\mathbf{4 b}(0.398 \mathrm{~g}, 1.28 \mathrm{mmol})$ was dissolved in toluene $(175 \mathrm{~mL})$ before triethylamine $(0.391 \mathrm{~g}, 0.540 \mathrm{~mL}, 3.86 \mathrm{mmol})$ was added and the solution stirred for $30 \mathrm{~min}$. Boron trifluoride diethyl etherate $(0.92 \mathrm{~g}, 0.80$ $\mathrm{mL}, 6.5 \mathrm{mmol}$ ) was then added and the solution heated to $80^{\circ} \mathrm{C}$ for $18 \mathrm{~h}$ During this time, the solution gradually changed color from dark red to purple. The solution was cooled to $20^{\circ} \mathrm{C}$ and deionized water $(15 \mathrm{~mL})$ was added to quench any remaining reactive species. The mixture was 
then washed with deionized water $(3 \times 50 \mathrm{~mL})$, dried over $\mathrm{MgSO}_{4}$, gravity filtered, and concentrated in vacuo to afford $7 \mathrm{~b}$ as a purple solid. The crude solid was purified via flash column chromatography (dichloromethane, neutral alumina) and recrystallized from a saturated methanolic solution to afford $\mathbf{7 b}$ as a purple microcrystalline solid. Yield = $0.221 \mathrm{~g}, 48 \%$. M.p. $143-145^{\circ} \mathrm{C} .{ }^{1} \mathrm{H}$ NMR $\left(599.5 \mathrm{MHz}, \mathrm{CDCl}_{3}\right): \delta 7.55$ (d ${ }^{3} J_{\mathrm{HH}}=9 \mathrm{~Hz}, 2 \mathrm{H}$, aryl $\left.\mathrm{C} \underline{H}\right), 7.42-7.40(\mathrm{~m}, 4 \mathrm{H}$, aryl $\mathrm{CH}), 7.08\left(\mathrm{dd},{ }^{3} \mathrm{~J}_{\mathrm{HH}}=8\right.$ $\mathrm{Hz},{ }^{4} J_{\mathrm{HH}}=3 \mathrm{~Hz}, 2 \mathrm{H}$, aryl $\left.\mathrm{C} \underline{H}\right), 3.89\left(\mathrm{~s}, 6 \mathrm{H}, \mathrm{OC}_{H_{3}}\right) .{ }^{13} \mathrm{C}\left\{{ }^{1} \mathrm{H}\right\} \operatorname{NMR}(150.8$ $\left.\mathrm{MHz}, \mathrm{CDCl}_{3}\right): \delta 160.4,144.1,130.2,118.2,116.0\left(\mathrm{t},{ }^{4} J_{\mathrm{CF}}=3 \mathrm{~Hz}\right), 114.0$, 107.6, 55.7. ${ }^{11} \mathrm{~B}$ NMR $\left(128.3 \mathrm{MHz}, \mathrm{CDCl}_{3}\right): \delta-0.8\left(\mathrm{t},{ }^{1} J_{\mathrm{BF}}=31 \mathrm{~Hz}\right) .{ }^{19} \mathrm{~F}$ (376.1 MHz, $\left.\mathrm{CDCl}_{3}\right): \delta-132.6\left(\mathrm{q},{ }^{1} J_{\mathrm{FB}}=29 \mathrm{~Hz}\right)$. FTIR $(\mathrm{KBr}): 3072(\mathrm{~m})$, $3016(\mathrm{~m}), 2958(\mathrm{~m}), 2850(\mathrm{~m}), 2237$ (s), 1605 (s), 1582 (s), 1487 (s), $1456(\mathrm{~m}), 1339(\mathrm{~s}), 1293(\mathrm{~m}), 1260(\mathrm{~s}), 1195(\mathrm{~m}), 1164(\mathrm{~m}), 1031(\mathrm{~s})$ $\mathrm{cm}^{-1}$. UV-vis (toluene): $\lambda_{\max } 525 \mathrm{~nm}\left(\varepsilon=21,100 \mathrm{M}^{-1} \mathrm{~cm}^{-1}\right) . \mathrm{MS}(\mathrm{EI}=+\mathrm{ve}$ mode): exact mass calculated for $\left[\mathrm{C}_{16} \mathrm{H}_{14} \mathrm{BF}_{2} \mathrm{~N}_{5} \mathrm{O}_{2}\right]^{+}$: 357.1209; exact mass found: 357.1198 ; difference: $-3.1 \mathrm{ppm}$.

Formazanate $\mathrm{BF}_{2}$ Complex $8 \mathrm{~b}\left(\mathrm{Ar}_{1}=\mathrm{Ar}_{5}=\boldsymbol{m}\right.$-anisole, $\left.\mathbf{R}_{3}=\mathrm{NO}_{2}\right)$. From $0.398 \mathrm{~g}(1.21 \mathrm{mmol})$ of formazan $5 \mathrm{~b}$. Yield $=0.111 \mathrm{~g}, 24 \%$ of dark purple microcrystalline solid. M.p. $78-80{ }^{\circ} \mathrm{C} .{ }^{1} \mathrm{H}$ NMR $\left(599.5 \mathrm{MHz} \mathrm{CDCl}_{3}\right): \delta$ 7.64-7.62 (m, 2H, aryl $\mathrm{C} \underline{H}), 7.52-7.50(\mathrm{~m}, 2 \mathrm{H}$, aryl $\mathrm{C} \underline{H}), 7.43\left(\mathrm{t},{ }^{3} \mathrm{~J}_{\mathrm{HH}}=8\right.$ $\mathrm{Hz}, 2 \mathrm{H}$, aryl $\mathrm{CH}$ ), 7.09 (dd, ${ }^{3} \mathrm{~J}_{\mathrm{HH}}=8 \mathrm{~Hz},{ }^{4} \mathrm{~J}_{\mathrm{HH}}=2 \mathrm{~Hz}, 2 \mathrm{H}$, aryl CH), 3.90 (s, $\left.6 \mathrm{H}, \mathrm{OC} \underline{H}_{3}\right) .{ }^{13} \mathrm{C}\left\{{ }^{1} \mathrm{H}\right\} \mathrm{NMR}\left(150.8 \mathrm{MHz}, \mathrm{CDCl}_{3}\right): \delta 160.5,144.2,130.3$, $118.5,116.3\left({ }^{4} J_{\mathrm{CF}}=4 \mathrm{~Hz}\right), 108.0,55.7 .{ }^{11} \mathrm{~B} \mathrm{NMR}\left(128.3 \mathrm{MHz}, \mathrm{CDCl}_{3}\right): \delta$ $-0.7\left(\mathrm{t},{ }^{1} J_{\mathrm{BF}}=29 \mathrm{~Hz}\right) .{ }^{19} \mathrm{~F}\left(376.1 \mathrm{MHz}, \mathrm{CDCl}_{3}\right): \delta-134.6\left(\mathrm{q},{ }^{1} J_{\mathrm{FB}}=29 \mathrm{~Hz}\right)$. FTIR (KBr): $3076(\mathrm{~m}), 3013(\mathrm{~m}), 2863(\mathrm{~m}), 1658(\mathrm{~m}), 1580(\mathrm{~m}), 1424(\mathrm{~m})$, $1266(\mathrm{~m}), 1095(\mathrm{~s}), 745(\mathrm{~m}) \mathrm{cm}^{-1}$. UV-vis (toluene): $\lambda_{\max } 533 \mathrm{~nm}(\varepsilon=$ $\left.18,400 \mathrm{M}^{-1} \mathrm{~cm}^{-1}\right)$. MS (EI = +ve mode): exact mass calculated for $\left[\mathrm{C}_{15} \mathrm{H}_{14} \mathrm{BF}_{2} \mathrm{~N}_{5} \mathrm{O}_{4}\right]^{+}$: 377.1107 ; exact mass found: 377.1104 ; difference: $-0.8 \mathrm{ppm}$.

Formazanate $\mathrm{BF}_{2}$ Complex $8 \mathrm{c}\left(\mathrm{Ar}_{1}=\mathrm{Ar}_{5}=\right.$ p-anisole, $\left.\mathbf{R}_{3}=\mathrm{NO}_{2}\right)$. From $1.19 \mathrm{~g}(3.60 \mathrm{mmol})$ of formazan $5 \mathrm{c}$. Yield $=0.291 \mathrm{~g}, 21 \%$ of dark purple microcrystalline solid. M.p. $154-156{ }^{\circ} \mathrm{C} .{ }^{1} \mathrm{H} \mathrm{NMR}\left(599.5 \mathrm{MHz}, \mathrm{CDCl}_{3}\right): \delta$ $7.99\left(\mathrm{~d},{ }^{3} \mathrm{~J}_{\mathrm{HH}}=9 \mathrm{~Hz}, 4 \mathrm{H}\right.$, aryl CH$), 7.01\left(\mathrm{dd},{ }^{3} \mathrm{~J}_{\mathrm{HH}}=9 \mathrm{~Hz},{ }^{4} \mathrm{~J}_{\mathrm{HH}}=2 \mathrm{~Hz}, 4 \mathrm{H}\right.$ aryl $\mathrm{CH}), 3.91\left(\mathrm{~s}, 6 \mathrm{H}, \mathrm{OC} \mathrm{H}_{3}\right) .{ }^{13} \mathrm{C}\left\{{ }^{1} \mathrm{H}\right\} \mathrm{NMR}\left(150.8 \mathrm{MHz}, \mathrm{CDCl}_{3}\right): \delta 162.4$, 137.0, 125.2, 114.9, 100.0, 55.8. ${ }^{11} \mathrm{~B}$ NMR $\left(128.3 \mathrm{MHz} \mathrm{CDCl}_{3}\right): \delta-0.7(\mathrm{t}$, $\left.{ }^{1} J_{\mathrm{BF}}=30 \mathrm{~Hz}\right) \cdot{ }^{19} \mathrm{~F}\left(376.1 \mathrm{MHz}, \mathrm{CDCl}_{3}\right): \delta-137.1$ (q, $\left.{ }^{1} J_{\mathrm{FB}}=29 \mathrm{~Hz}\right)$. FTIR (KBr): $3058(\mathrm{~m}), 3011(\mathrm{~m}), 2993(\mathrm{~m}), 1656(\mathrm{~m}), 1580(\mathrm{w}), 1420(\mathrm{~m}), 1340$ (w), $1270(\mathrm{~s}), 1151(\mathrm{w}), 900(\mathrm{~m}), 745(\mathrm{~m}) \mathrm{cm}^{-1}$. UV-vis (toluene): $\lambda_{\max } 579$ $\mathrm{nm}\left(\varepsilon=23,600 \mathrm{M}^{-1} \mathrm{~cm}^{-1}\right)$. MS (El = +ve mode): exact mass calculated for $\left[\mathrm{C}_{15} \mathrm{H}_{14} \mathrm{BF}_{2} \mathrm{~N}_{5} \mathrm{O}_{4}\right]^{+}: 377.1107$; exact mass found: 377.1101 ; difference: $-1.6 \mathrm{ppm}$

Formazanate $\mathrm{BF}_{2}$ Complex $9 \mathrm{a}\left(\mathrm{Ar}_{1}=\mathrm{Ar}_{5}=\right.$ o-anisole, $\left.\mathbf{R}_{3}=\mathrm{Ph}\right)$. This complex required additional purification by flash column chromatography (toluene, silica gel). From $0.396 \mathrm{~g}(1.10 \mathrm{mmol})$ of formazan $6 \mathrm{a}$. Yield = $0.212 \mathrm{~g}, 47 \%$ of an orange solid. M.p. $158-160^{\circ} \mathrm{C}$. ${ }^{1} \mathrm{H}$ NMR $(399.5 \mathrm{MHz}$, $\left.\mathrm{CDCl}_{3}\right): \delta$ 8.08-8.06 (m, $2 \mathrm{H}$, aryl $\left.\mathrm{CH}\right), 7.46-7.38(\mathrm{~m}, 5 \mathrm{H}$, aryl $\mathrm{CH})$, 7.23-7.22 (m, 2H, aryl $\mathrm{C} \underline{H}), 7.04-6.99(\mathrm{~m}, 4 \mathrm{H}$, aryl $\mathrm{C} \underline{H}), 3.92(\mathrm{~s}, 6 \mathrm{H}$, $\left.\mathrm{OCH}_{3}\right) .{ }^{13} \mathrm{C}\left\{{ }^{1} \mathrm{H}\right\}$ NMR $\left(100.6 \mathrm{MHz}, \mathrm{CDCl}_{3}\right): \delta 155.0,151.5,133.3,133.1$, $130.9,129.2,128.5,127.3,125.7,120.6,112.5,56.3 .{ }^{11} \mathrm{~B}$ NMR $(128.3$ $\left.\mathrm{MHz}, \mathrm{CDCl}_{3}\right): \delta-1.2\left(\mathrm{t},{ }^{1} \mathrm{~J}_{\mathrm{BF}}=19 \mathrm{~Hz}\right) .{ }^{19} \mathrm{~F} \mathrm{NMR}\left(376.1 \mathrm{MHz}, \mathrm{CDCl}_{3}\right): \delta$ $-160.6\left(\mathrm{q},{ }^{1} \mathrm{~J}_{\mathrm{FB}}=19 \mathrm{~Hz}\right) . \mathrm{FTIR}(\mathrm{KBr}): 3057(\mathrm{~m}), 2988(\mathrm{~m}), 2967(\mathrm{w}), 2843$ $(\mathrm{m}), 1666(\mathrm{~m}), 1496(\mathrm{~s}), 1441(\mathrm{~m}), 1359(\mathrm{~m}), 1268(\mathrm{~s}), 1124(\mathrm{~s}), 1050$ $(\mathrm{m}), 897(\mathrm{~m}), 745(\mathrm{~m}) \mathrm{cm}^{-1}$. UV-vis (toluene): $\lambda_{\max } 467 \mathrm{~nm}(\varepsilon=18,800$ $\mathrm{M}^{-1} \mathrm{~cm}^{-1}$ ). Mass Spec. (El, +ve mode): exact mass calculated for $\left[\mathrm{C}_{21} \mathrm{H}_{19} \mathrm{BF}_{2} \mathrm{~N}_{4} \mathrm{O}_{2}\right]^{+}$: 408.1569; exact mass found: 408.1564; difference: $-1.2 \mathrm{ppm}$

Formazanate $\mathrm{BF}_{2}$ Complex $\mathbf{9 b}\left(\mathrm{Ar}_{1}=\mathrm{Ar}_{5}=\boldsymbol{m}\right.$-anisole, $\left.\mathbf{R}_{3}=\mathrm{Ph}\right)$. From $0.613 \mathrm{~g}(1.70 \mathrm{mmol})$ of formazan $6 \mathrm{~b}$. Yield $=0.621 \mathrm{~g}, 90 \%$ of a purplered solid. M.p. $76-78^{\circ} \mathrm{C}$. ${ }^{1} \mathrm{H}$ NMR $\left(399.8 \mathrm{MHz} \mathrm{CDCl}_{3}\right): \delta 8.14-8.13(\mathrm{~m}$, $2 \mathrm{H}$, aryl $\mathrm{C} \underline{H}), 7.57-7.56(\mathrm{~m}, 2 \mathrm{H}$, aryl $\mathrm{CH}), 7.52-7.49(\mathrm{~m}, 2 \mathrm{H}$, aryl $\mathrm{C} \underline{H})$, 7.47-7.46 (m, 3H, aryl $\mathrm{C} \underline{H}), 7.41-7.39(\mathrm{~m}, 2 \mathrm{H}$, aryl $\mathrm{C} \underline{H}), 7.02-7.01(\mathrm{~m}$
$2 \mathrm{H}$, aryl $\mathrm{C} \underline{H}$ ), 3.89 (s, $\left.6 \mathrm{H}, \mathrm{OC}_{H_{3}}\right) .{ }^{13} \mathrm{C}\left\{{ }^{1} \mathrm{H}\right\} \mathrm{NMR}\left(100.6 \mathrm{MHz}, \mathrm{CDCl}_{3}\right): \delta$ $160.1,148.9,145.0,133.5,129.8,129.3,128.7,125.5,116.1(\mathrm{~m}), 116.0$, 108.5, 55.5. ${ }^{11} \mathrm{~B}$ NMR (128.3 MHz, $\left.\mathrm{CDCl}_{3}\right): \delta-0.6\left(\mathrm{t},{ }^{1} J_{\mathrm{BF}}=29 \mathrm{~Hz}\right) .{ }^{19} \mathrm{~F}$ NMR $\left(376.1 \mathrm{MHz}, \mathrm{CDCl}_{3}\right): \delta-144.2\left(\mathrm{q},{ }^{1} \mathrm{~J}_{\mathrm{FB}}=28 \mathrm{~Hz}\right)$. FTIR $(\mathrm{KBr}): 3058$ (m), $2989(\mathrm{~m}), 2900(\mathrm{~m}), 2841(\mathrm{w}), 1667(\mathrm{~m}), 1605(\mathrm{~m}), 1494(\mathrm{~m}), 1424$ $(\mathrm{m}), 1357$ (w), 1267 (s), $1119(\mathrm{~m}), 897(\mathrm{w}), 745(\mathrm{~m}) \mathrm{cm}^{-1}$. UV-vis (toluene): $\lambda_{\max } 530 \mathrm{~nm}\left(\varepsilon=22,900 \mathrm{M}^{-1} \mathrm{~cm}^{-1}\right)$. Mass Spec. (El, +ve mode): exact mass calculated for $\left[\mathrm{C}_{21} \mathrm{H}_{19} \mathrm{BF}_{2} \mathrm{~N}_{4} \mathrm{O}_{2}\right]^{+}$: 408.1569; exact mass found: 408.1570 ; difference: $+0.2 \mathrm{ppm}$

Formazanate $\mathrm{BF}_{2}$ Complex $9 \mathrm{c}\left(\mathrm{Ar}_{1}=\mathrm{Ar}_{5}=p\right.$-anisole, $\left.\mathbf{R}_{3}=\mathrm{Ph}\right)$. From $1.00 \mathrm{~g}(2.80 \mathrm{mmol})$ of formazan $6 \mathrm{c}$. Yield $=0.711 \mathrm{~g}, 62 \%$ of a dark purple solid. M.p. $170-172{ }^{\circ} \mathrm{C}$. ${ }^{1} \mathrm{H}$ NMR $\left(399.8 \mathrm{MHz} \mathrm{CDCl}_{3}\right): \delta 8.12\left(\mathrm{~d},{ }^{3} \mathrm{~J}_{\mathrm{HH}}=7\right.$ $\mathrm{Hz}, 2 \mathrm{H}$, aryl $\mathrm{CH}), 7.88\left(\mathrm{~d},{ }^{3} \mathrm{~J}_{\mathrm{HH}}=9 \mathrm{~Hz}, 4 \mathrm{H}\right.$, aryl $\left.\mathrm{CH}\right), 7.49-7.41(\mathrm{~m}, 3 \mathrm{H}$, aryl $\mathrm{C} \underline{H}), 6.98\left(\mathrm{~d},{ }^{3} \mathrm{~J}_{\mathrm{HH}}=9 \mathrm{~Hz}, 4 \mathrm{H}\right.$, aryl $\left.\mathrm{C} \underline{H}\right), 3.88\left(\mathrm{~s}, 6 \mathrm{H}, \mathrm{OC} \underline{H}_{3}\right) .{ }^{13} \mathrm{C}\left\{{ }^{1} \mathrm{H}\right\}$ NMR $\left(100.6 \mathrm{MHz}, \mathrm{CDCl}_{3}\right): \delta 160.7,137.6,134.0,128.9,128.6,125.4$, 124.9, 114.3, 55.6. ${ }^{11} \mathrm{~B}$ NMR (128.3 $\left.\mathrm{MHz} \mathrm{CDCl}_{3}\right): \delta-0.4\left(\mathrm{t},{ }^{1} \mathrm{~J}_{\mathrm{BF}}=29\right.$ $\mathrm{Hz}) .{ }^{19} \mathrm{~F} N M R\left(376.1 \mathrm{MHz}, \mathrm{CDCl}_{3}\right): \delta-145.3\left(\mathrm{q},{ }^{1} J_{\mathrm{FB}}=29 \mathrm{~Hz}\right)$. FTIR $(\mathrm{KBr}): 2948(\mathrm{~m}), 2900(\mathrm{~m}), 2834(\mathrm{~m}), 1641$ (s), $1596(\mathrm{~s}), 1508(\mathrm{~s}), 1313$ (m), 1249 (s), 1164 (s) $\mathrm{cm}^{-1}$. UV-vis (toluene): $\lambda_{\max } 551 \mathrm{~nm}(\varepsilon=25,500$ $\mathrm{M}^{-1} \mathrm{~cm}^{-1}$ ). Mass Spec. (El, +ve mode): exact mass calculated for $\left[\mathrm{C}_{21} \mathrm{H}_{19} \mathrm{BF}_{2} \mathrm{~N}_{4} \mathrm{O}_{2}\right]^{+}$: 408.1569; exact mass found: 408.1576; difference: $+1.7 \mathrm{ppm}$

Preparation of Formazanate $\mathrm{BF}_{2}$ Complex $8 \mathrm{a}\left(\mathrm{Ar}_{1}=\mathbf{A r}_{5}=0\right.$-anisole, $\left.\mathbf{R}_{3}=\mathbf{N O}_{2}\right)$. Formazan $5 \mathrm{a}(1.00 \mathrm{~g}, 3.04 \mathrm{mmol})$ was dissolved in toluene $(250 \mathrm{~mL})$ before triethylamine $(2.82 \mathrm{~g}, 3.90 \mathrm{~mL}, 27.9 \mathrm{mmol})$ was added and the solution stirred for $30 \mathrm{~min}$. Boron trifluoride diethyl etherate $(6.44$ $\mathrm{g}, 5.60 \mathrm{~mL}, 45.4 \mathrm{mmol}$ ) was added and the solution heated with stirring at $105^{\circ} \mathrm{C}$ for $144 \mathrm{~h}$ at which time the solution was dark purple with a blue hue on the sides of the flask. The solution was cooled to $20^{\circ} \mathrm{C}$ and poured directly onto a column containing neutral alumina. After the toluene solution was adsorbed onto the alumina, dichloromethane was used as the eluent. The crude product was isolated as a bright orange solution, which was washed with deionized water $(3 \times 1.00 \mathrm{~L})$. The organic layer was collected, dried over $\mathrm{MgSO}_{4}$, gravity filtered, and concentrated in vacuo to afford $\mathbf{8 a}$ as a red-orange solid. The crude solid was purified via flash column chromatography (toluene, neutral alumina, $\mathrm{R}_{\mathrm{f}}=0.33$ ) to afford $8 \mathrm{a}$ as a bright orange powder. Yield $=0.163 \mathrm{~g}, 15 \%$. $\mathrm{Mp}=166-168{ }^{\circ} \mathrm{C} .{ }^{1} \mathrm{H}$ NMR $\left(599.5 \mathrm{MHz}, \mathrm{CDCl}_{3}\right): \delta 7.47\left(\mathrm{t},{ }^{3} \mathrm{~J}_{\mathrm{HH}}=8 \mathrm{~Hz}\right.$, $2 \mathrm{H}$, aryl $\mathrm{C} \underline{H}), 7.36\left(\mathrm{~d},{ }^{3} \mathrm{~J}_{\mathrm{HH}}=8 \mathrm{~Hz}, 2 \mathrm{H}\right.$, aryl $\left.\mathrm{C} \underline{H}\right), 7.06-7.03(\mathrm{~m}, 4 \mathrm{H}$, aryl $\mathrm{C} \underline{H}), 3.92\left(\mathrm{~s}, 6 \mathrm{H}, \mathrm{OC} \underline{H}_{3}\right) .{ }^{13} \mathrm{C}\left\{{ }^{1} \mathrm{H}\right\}$ NMR $\left(150.8 \mathrm{MHz}, \mathrm{CDCl}_{3}\right): \delta 155.0$, $132.9,132.7,127.3,120.9$ (2C), 112.9, 56.5. ${ }^{11} \mathrm{~B}$ NMR $(128.3 \mathrm{MHz}$, $\left.\mathrm{CDCl}_{3}\right): \delta-1.6\left(\mathrm{t},{ }^{1} \mathrm{~J}_{\mathrm{BF}}=19 \mathrm{~Hz}\right) .{ }^{19} \mathrm{~F} \mathrm{NMR}\left(376.1 \mathrm{MHz}, \mathrm{CDCl}_{3}\right): \delta-156.0$ $\left(\mathrm{q},{ }^{1} J_{\mathrm{FB}}=18 \mathrm{~Hz}\right)$. FTIR $(\mathrm{KBr}): 3035(\mathrm{~m}), 2974(\mathrm{~m}), 2845(\mathrm{~m}), 1660(\mathrm{~m})$, $1587(\mathrm{~m}), 1557(\mathrm{~m}), 1494(\mathrm{~m}), 1332(\mathrm{~m}), 1260(\mathrm{~m}), 1100(\mathrm{~s}), 1021(\mathrm{~m})$, $814(\mathrm{~m}), 751(\mathrm{~m}) \mathrm{cm}^{-1}$. UV-vis (toluene): $\lambda_{\max } 468 \mathrm{~nm}\left(\varepsilon=7,500 \mathrm{M}^{-1}\right.$ $\left.\mathrm{cm}^{-1}\right)$. MS (El = +ve mode): exact mass calculated for $\left[\mathrm{C}_{15} \mathrm{H}_{14} \mathrm{BF}_{2} \mathrm{~N}_{5} \mathrm{O}_{4}\right]^{+}$. 377.1107; exact mass found: 377.1101 ; difference: $-1.6 \mathrm{ppm}$.

\section{Acknowledgements}

This work was supported by the Natural Sciences and Engineering Research Council (NSERC) of Canada Discovery Grants (L. G. L. and J. B. G.), Undergraduate Student Research Award (R. R. M.), and Canada Graduate Scholarships program (S. M. B.), the University of Western Ontario, and a PetroCanada Young Innovator Award (J. B. G.). We thank Profs. Elizabeth R. Gillies and Mark S. Workentin for access to instrumentation within their labs. 
Keywords: Formazanate Ligands • Boron • Fluorescent Dyes • Cell Imaging • Substituent Effects

[1] Review: D. Frath, J. Massue, G. Ulrich, R. Ziessel, Angew. Chem. Int. Ed. 2014, 53, 2290-2310.

[2] Selected examples: a) J. F. Araneda, W. E. Piers, B. Heyne, M. Parvez, R. McDonald, Angew. Chem. Int. Ed. 2011, 50, 12214-12217; b) Y. Kubota, Y. Ozaki, K. Funabiki, M. Matsui, J. Org. Chem. 2013, 78, 7058-7067; c) G. Nawn, S. R. Oakley, M. B. Majewski, R. McDonald, B. O. Patrick, R. G. Hicks, Chem. Sci. 2013, 4, 612-621; d) C. Bonnier, D. D. Machin, O. Abdi, B. D. Koivisto, Org. Biomol. Chem. 2013, 11, 3756-3760; e) D. Frath, A Poirel, G. Ulrich, A. De Nicola, R. Ziessel, Chem. Commun. 2013, 49, 4908-4910; f) A. Díaz-Moscoso, E. Emond, D. L. Hughes, G. J. Tizzard, S. J. Coles, A. N. Cammidge, J. Org. Chem. 2014, 79, 8932-8936; g) I.-S. Tamgho, A. Hasheminasab, J. T. Engle, V. N. Nemykin, C. J. Ziegler, J. Am. Chem. Soc. 2014, 136, 5623-5626; h) S. T. Manjare, J. Kim, Y. Lee, D. G. Churchill, Org. Lett. 2014, 16, 520-523.

[3] Reviews: a) R. Ziessel, G. Ulich, A. Harriman, New J. Chem. 2007, 31, 496-501; b) A. Loudet, K. Burgess, Chem. Rev. 2007, 107, 4891-4932; c) Y. Ni, J. Wu, Org. Biomol. Chem. 2014, 12, 3774-3791.

[4] Review: N. Boens, V. Leen, W. Dehaen, Chem. Soc. Rev. 2012, 41, 1130-1172.

[5] Selected examples: a) T. W. Hudnall, F. P. Gabbaï, Chem. Commun. 2008, 4596-4597; b) A. Nierth, A. Y. Kobitski, G. U. Nienhaus, A. Jäschke J. Am. Chem. Soc. 2010, 132, 2646-2654; c) M. A. H. Alamiry, J. P. Hagon, A. Harriman, T. Bura, R. Ziessel, Chem. Sci. 2012, 3, 1041-1048; d) S. T. Manjare, S. Kim, W. D. Heo, D. G. Churchill, Org. Lett. 2014, 16 410-412; e) S. Raut, J. Kimball, R. Fudala, H. Doan, B. Maliwal, N Sabnis, A. Lacko, I. Gryczynski, S. V. Dzyuba, Z. Gryczynski, Phys. Chem Chem. Phys. 2014, 16, 27037-27042; f) X.-D. Jiang, Y. Su, S. Yue, C. Li, H. Yu, H. Zhang, C.-L. Sun, L.-J. Xiao, RSC Adv. 2015, 5, 16735-16739.

[6] Review: A. B. Nepomnyashchii, A. J. Bard, Acc. Chem. Res. 2012, 45, 1844-1853.

[7] Selected examples: a) A. B. Nepomnyashchii, S. Cho, P. J. Rossky, A. J. Bard, J. Am. Chem. Soc. 2010, 132, 17550-17559; b) A. B. Nepomnyashchii, M. Bröring, J. Ahrens, A. J. Bard, J. Am. Chem. Soc 2011, 133, 8633-8645; c) M. Hesari, S. M. Barbon, V. N. Staroverov, Z. Ding, J. B. Gilroy, Chem. Commun. 2015, 51, 3766-3769; d) M. Hesari, J.-s. Lu, S. Wang, Z. Ding, Chem. Commun. 2015, 51, 1081-1084.

[8] Selected examples: a) L. Bonardi, H. Kanaan, F. Camerel, P. Jolinat, P. Retailleau, R. Ziessel, Adv. Funct. Mater. 2008, 18, 401-413; b) T. Rousseau, A. Cravino, T. Bura, G. Ulrich, R. Ziessel, J. Roncali, Chem. Commun. 2009, 1673-1675; c) H. Usta, M. D. Yilmaz, A.-J. Avestro, D Boudinet, M. Denti, W. Zhao, J. F. Stoddart, A. Facchetti, Adv. Mater. 2013, 25, 4327-4334; d) N. J. Findlay, J. Bruckbauer, A. R. Inigo, B. Breig, S. Arumugam, D. J. Wallis, R. W. Martin, P. J. Skabara, Adv. Mater. 2014, 26, 7290-7294; e) J. J. Chen, S. M. Conron, P. Erwin, M. Dimitriou, K. McAlahney, M. E. Thompson, ACS Appl. Mater. Interfaces 2015, 7, 662-669.

[9] Reviews: a) S. G. Awuah, Y. You, RSC Adv. 2012, 2, 11169-11183; b) A. Kamkaew, S. H. Lim, H. B. Lee, L. V. Kiew, L. Y. Chung, K. Burgess, Chem. Soc. Rev. 2013, 42, 77-88.

[10] Selected examples: a) A. Kamkaew, K. Burgess, J. Med. Chem. 2013, 56, 7608-7614; b) Y.-C. Lai, S.-Y. Su, C.-C. Chang, ACS Appl. Mater Interfaces 2013, 5, 12935-12943; c) R. L. Watley, S. G. Awuah, M. Bio, R. Cantu, H. B. Gobeze, V. N. Nesterov, S. K. Das, F. D'Souza, Y. You, Chem. Asian J. 2015, 10, 1335-1343.

[11] Review: T. Kowada, H. Maeda, K. Kikuchi, Chem. Soc. Rev. 2015, 44, 4953-4972.

[12] Selected examples: a) T. Komatsu, Y. Urano, Y. Fujikawa, T. Kobayashi, H. Kojima, T. Terai, K. Hanaoka, T. Nagano, Chem. Commun. 2009, 7015-7017; b) Y. Ueno, J. Jose, A. Loudet, C. Pérez-Bolívar, P. Anzenbacher, Jr., K. Burgess, J. Am. Chem. Soc. 2011, 133, 51-55; c) R. Hu, C. F. A. Gómez-Durán, J. W. Y. Lam, J. L. Belmonte-Vázquez, C.
Deng, S. Chen, R. Ye, E. Peña-Cabrera, Y. Zhong, K. S. Wong, B. Z. Tang, Chem. Commun. 2012, 48, 10099-10101; d) T. Gayathri, A. K. Barui, S. Prashanthi, C. R. Patra, S. P. Singh, RSC Adv. 2014, 4, 47409-47413; e) J. J. Hu, N.-K. Wong, Q. Gu, X. Bai, S. Ye, D. Yang, Org. Lett. 2014, 16, 3544-3547; f) F. Wang, Y. Zhu, L. Zhou, L. Pan, Z. Cui, Q. Fei, S. Luo, D. Pan, Q. Huang, R. Wang, C. Zhao, H. Tian, C. Fan, Angew. Chem. Int. Ed. 2015, 54, 7349-7353; g) A. K. Yadav, D. L. Shen, X. Shan, X. He, A. R. Kermode, D. J. Vocadlo, J. Am. Chem. Soc. 2015, 137, 1181-1189; h) A. Kamkaew, S. Thavornpradit, T. Puangsamlee, D. Xin, N. Wanichacheva, K. Burgess, Org. Biomol. Chem. 2015, 13, 8271-8276.

[13]a) M.-C. Chang, E. Otten, Chem. Commun. 2014, 50, 7431-7433; b) S. M. Barbon, P. A. Reinkeluers, J. T. Price, V. N. Staroverov, J. B. Gilroy, Chem. Eur. J. 2014, 20, 11340-11344; c) S. M. Barbon, J. T. Price, P. A. Reinkeluers, J. B. Gilroy, Inorg. Chem. 2014, 53, 10585-10593; d) S. M. Barbon, V. N. Staroverov, J. B. Gilroy, J. Org. Chem. 2015, 80, 5226-5235; e) S. M. Barbon, J. T. Price, U. Yograjah, J. B. Gilroy, RSC Adv. 2015, 5, 56316-56324; M.-C. Chang, E. Otten, Inorg. Chem. 2015, 54, DOI: $10.1021 /$ acs.inorgchem.5b01287.

[14] Reviews: a) A. W. Nineham, Chem. Rev. 1955, 55, 355-483; b) A. S. Shawali, N. A. Samy, J. Adv. Res. 2015, 6, 241-254.

[15] Review: M. V. Berridge, P. M. Herst, A. S. Tan, Biotechnol. Annu. Rev. 2005, 11, 127-152.

[16] J. B. Gilroy, P. O. Otieno, M. J. Ferguson, R. McDonald, R. G. Hicks, Inorg. Chem. 2008, 47, 1279-1286.

[17] G. I. Sigeiken, G. N. Lipunova, I. G. Pervova, Russ. Chem. Rev. 2006, 75, 885-900.

[18] Selected examples: a) D. A. Brown, H. Bögge, G. N. Lipunova, A. Müller, W. Plass, K. G. Walsh, Inorg. Chim. Acta 1998, 280, 30-38; b) J. B. Gilroy, M. J. Ferguson, R. McDonald, B. O. Patrick, R. G. Hicks, Chem. Commun. 2007, 126-128; c) J. B. Gilroy, M. J. Ferguson, R. McDonald, R. G. Hicks, Inorg. Chim. Acta 2008, 361, 3388-3393; d) J. B. Gilroy, B. O. Patrick, R McDonald, R. G. Hicks, Inorg. Chem. 2008, 47, 1287-1294; e) S. Hong, L. M. R. Hill, A. K. Gupta, B. D. Naab, J. B. Gilroy, R. G. Hicks, C. J. Cramer, W. B. Tolman, Inorg. Chem. 2009, 48, 4514-4523; f) S. Hong, A. K. Gupta, W. B. Tolman, Inorg. Chem. 2009, 48, 6323-6325; g) M.-C. Chang, T. Dann, D. P. Day, M. Lutz, G. G. Wildgoose, E. Otten, Angew. Chem. Int. Ed. 2014, 53, 4118-4122; h) R. Travieso-Puente, M.-C. Chang, E. Otten, Dalton Trans. 2014, 43, 18035-18041; i) M.-C. Chang, P. Roewen, R. Travieso-Puente, M. Lutz, E. Otten, Inorg. Chem. 2015, 54, 379-388; j) N. A. Protasenko, A. I. Poddel'sky, A. S. Bogomyakov, G. K. Fukin, V. K. Cherkasov, Inorg. Chem. 2015, 54, 6078-6080.

[19] a) Y. A. Ibrahim, A. H. M. Elwahy, A. A. Abbas, Tetrahedron 1994, 50, 11489-11498; b) K. G. von Eschwege, G. Bosman, J. Conradie, H. Schwoerer, J. Phys. Chem. A 2014, 118, 844-855.

[20] 2-Ethylbenzenediazonium chloride proved to be highly unstable, which resulted in an isolated yield of just $9 \%$ for 3-cyanoformazan $\mathbf{4 d}$.

[21] W. M. Haynes, CRC Handbook of Chemistry and Physics, 93rd ed., CRC Press, Boca Raton, Fla, 2012.

[22] a) S. Fery-Forgues, D. Lavabre, J. Chem. Educ. 1999, 76, 1260-1264; b) K. Suzuki, A. Kobayashi, S. Kaneko, K. Takehira, T. Yoshihara, H. Ishida Y. Shiina, S. Oishi, S. Tobita, Phys. Chem. Chem. Phys. 2009, 11, 9850-9860.

[23] SAINT version 2013.2018, Bruker-AXS, 2013, Madison, WI 53711, USA.

[24] SADABS version 2012.2011, Bruker-AXS, 2012, Madison, WI 53711, USA.

[25] G. M. Sheldrick, Acta Crystallogr. 2015, A71, 3-8.

[26] G. M. Sheldrick, Acta Crystallogr. 2008, A64, 112-122. 


\section{Entry for the Table of Contents}

\section{FULL PAPER}

The evaluation of nine boron difluoride formazanate complexes bearing $o^{-}, m$ - and $p$-anisole $\mathrm{N}$-ary substituents as readily accessible alternatives to boron dipyrromethene (BODIPY) dyes for cell imaging applications is presented. Highlights include the demonstration of the dramatic effect of anisole substitution patterns on the properties of the resulting complexes and the utility of a champion complex for fluorescence cell imaging of the cytoplasm of mouse fibroblast cells.

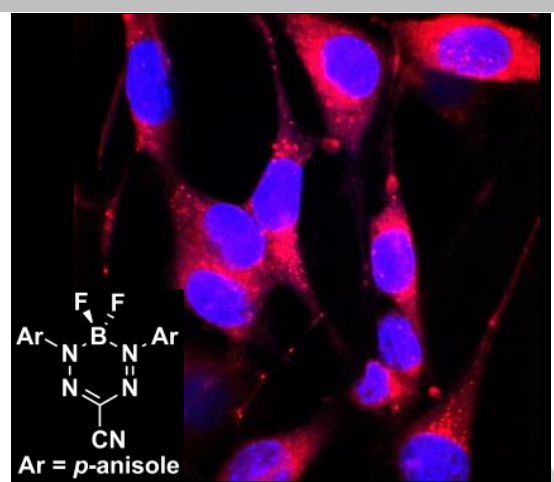

Ryan R. Maar, Stephanie M. Barbon, Neha Sharma, Hilary Groom, Leonard G. Luyt, ${ }^{*}$ and Joe B. Gilroy*

Page No. - Page No.

Evaluation of Anisole-Substituted Boron Difluoride Formazanate Complexes for Fluorescence Cell Imaging 


\section{Table of Contents}

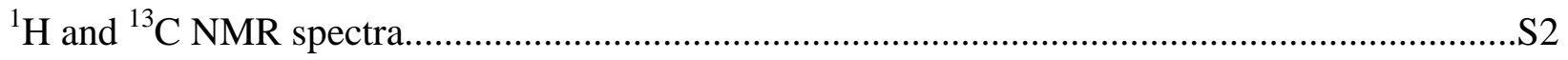

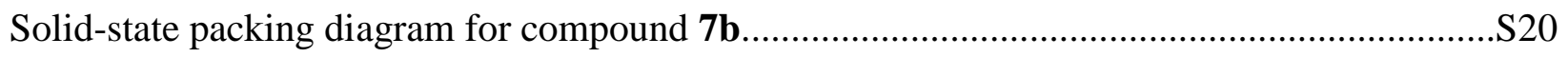

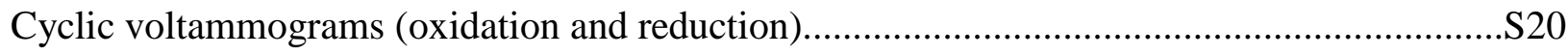

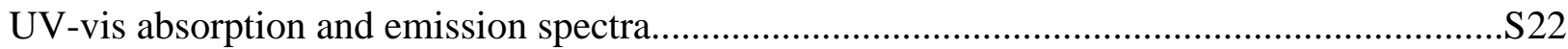




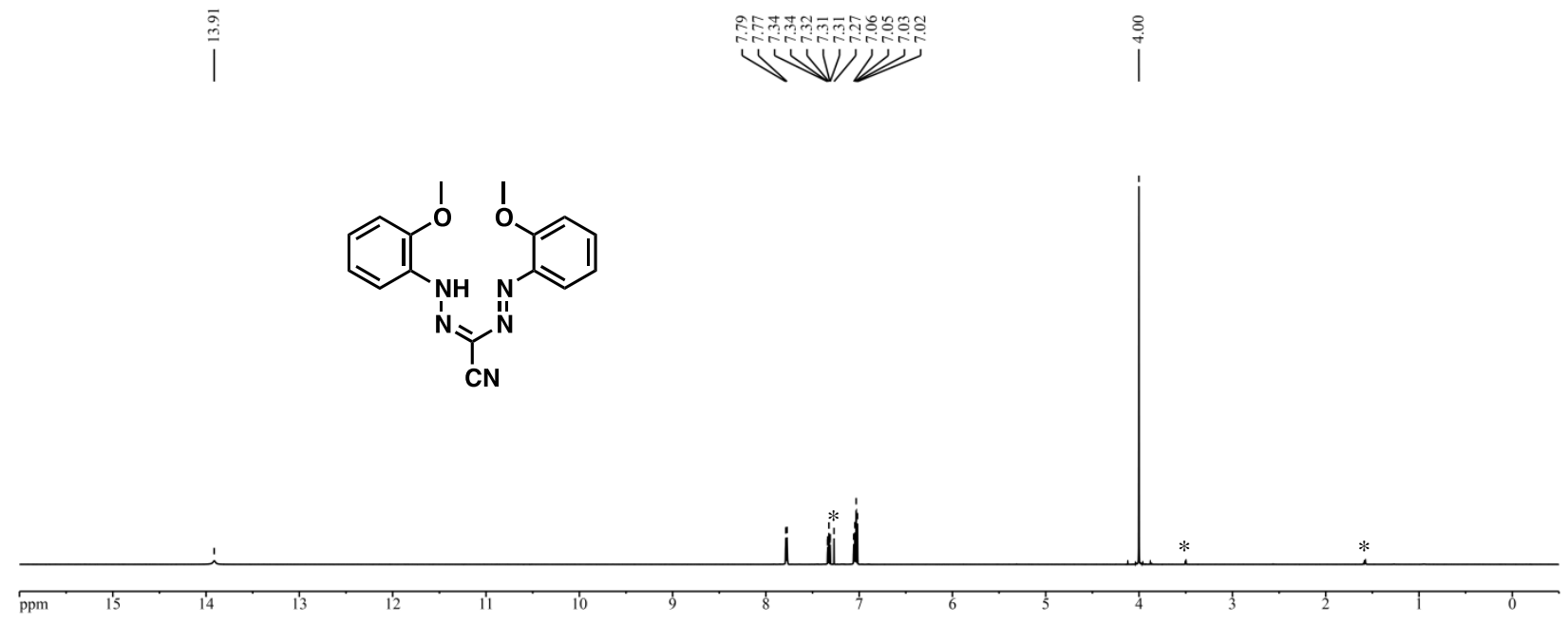

Figure S1. ${ }^{1} \mathrm{H} \mathrm{NMR}$ spectrum of $\mathbf{4 a}$ in $\mathrm{CDCl}_{3}$. The asterisks denote residual solvent signals.

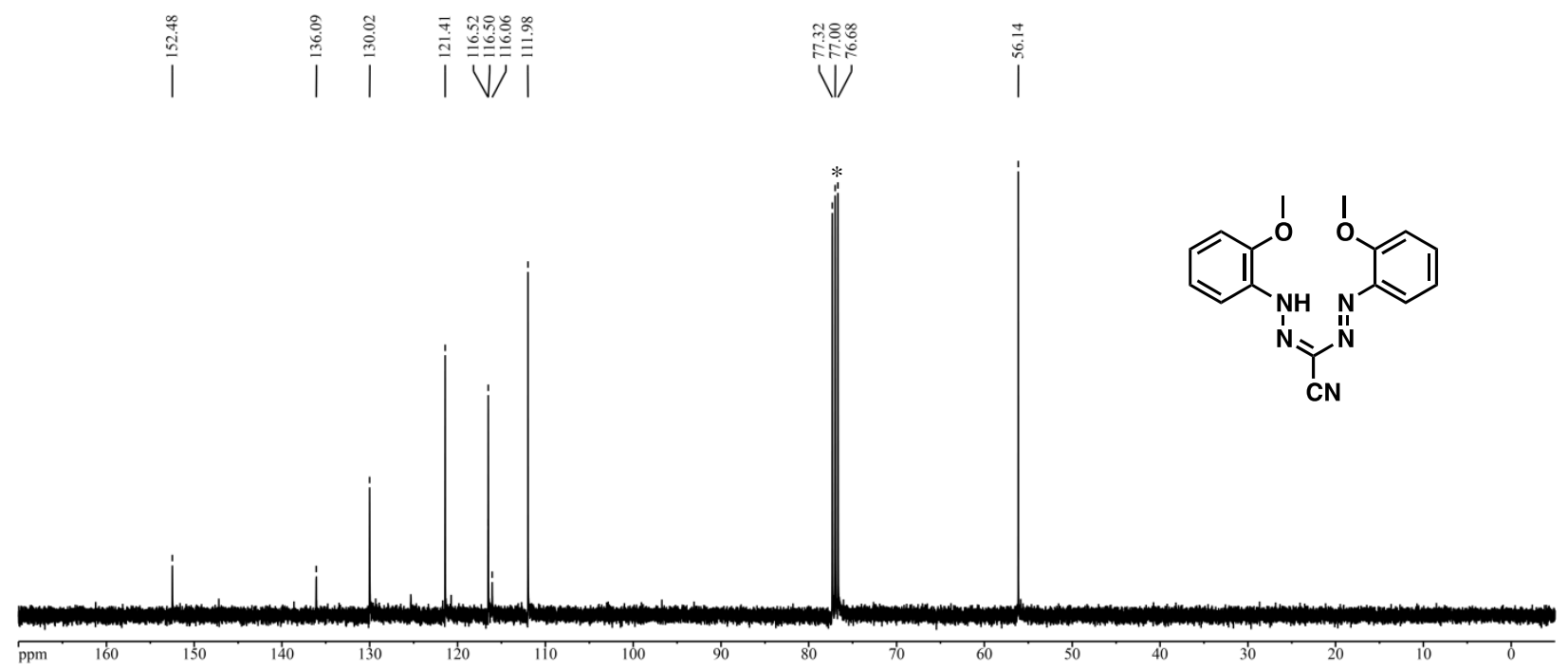

Figure S2. ${ }^{13} \mathrm{C}\left\{{ }^{1} \mathrm{H}\right\}$ NMR spectrum of $\mathbf{4 a}$ in $\mathrm{CDCl}_{3}$. The asterisk denotes solvent signal. 


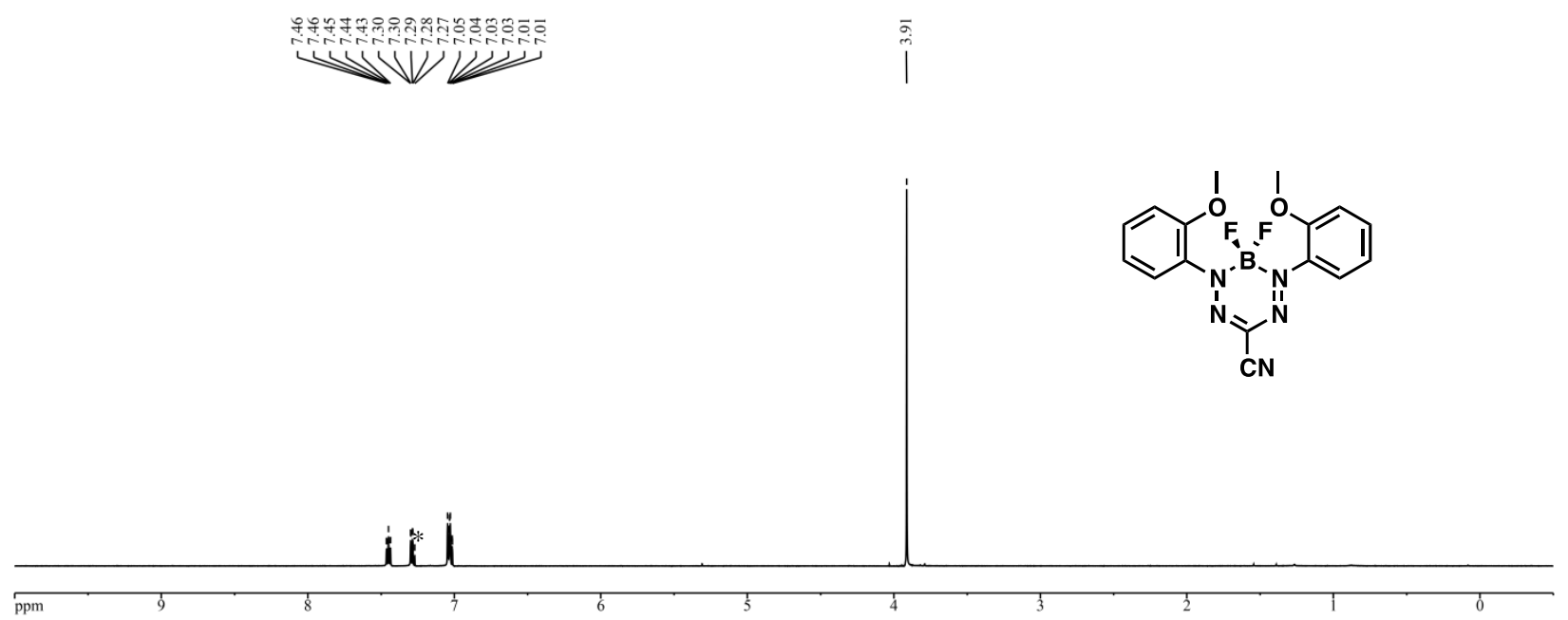

Figure S3. ${ }^{1} \mathrm{H}$ NMR spectrum of $7 \mathbf{a}$ in $\mathrm{CDCl}_{3}$. The asterisk denotes residual solvent signal.

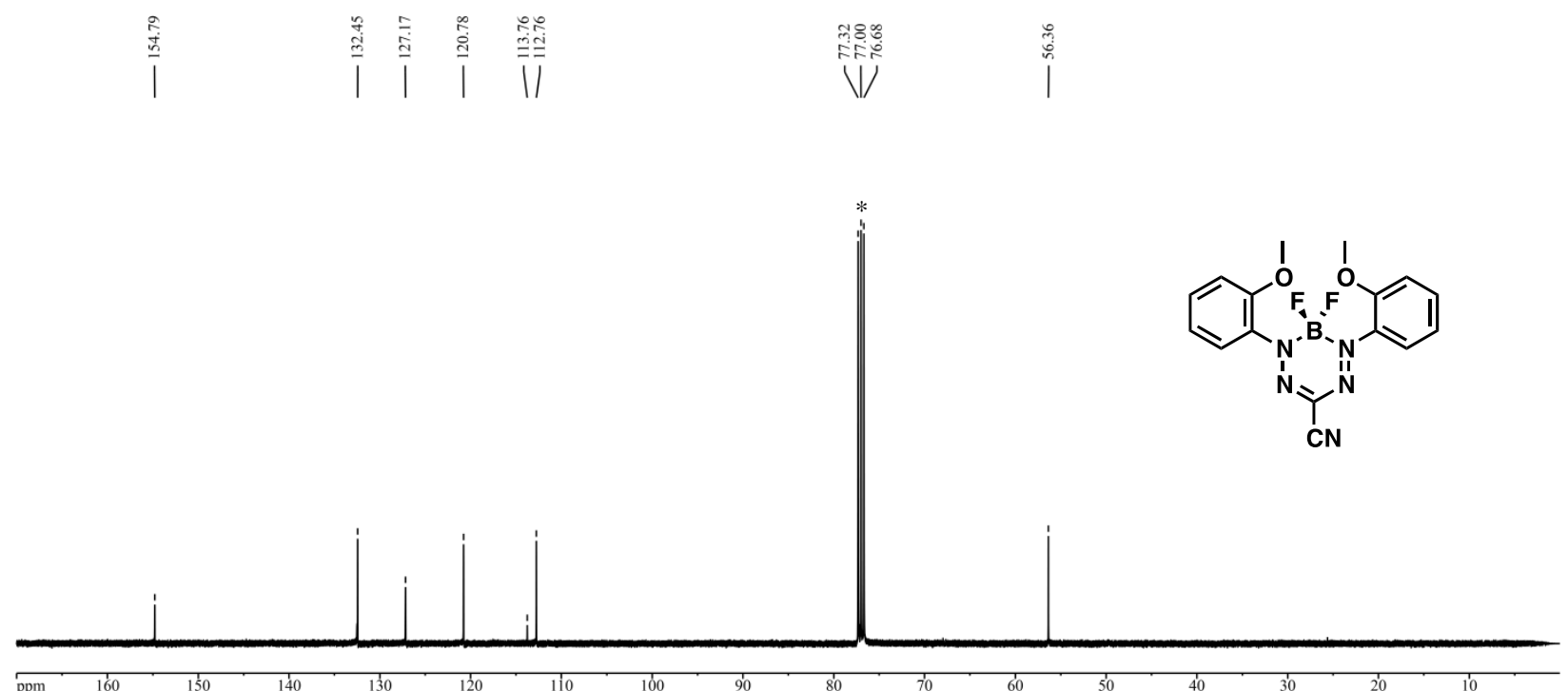

Figure S4. ${ }^{13} \mathrm{C}\left\{{ }^{1} \mathrm{H}\right\}$ NMR spectrum of $\mathbf{7 a}$ in $\mathrm{CDCl}_{3}$. The asterisk denotes solvent signal. 


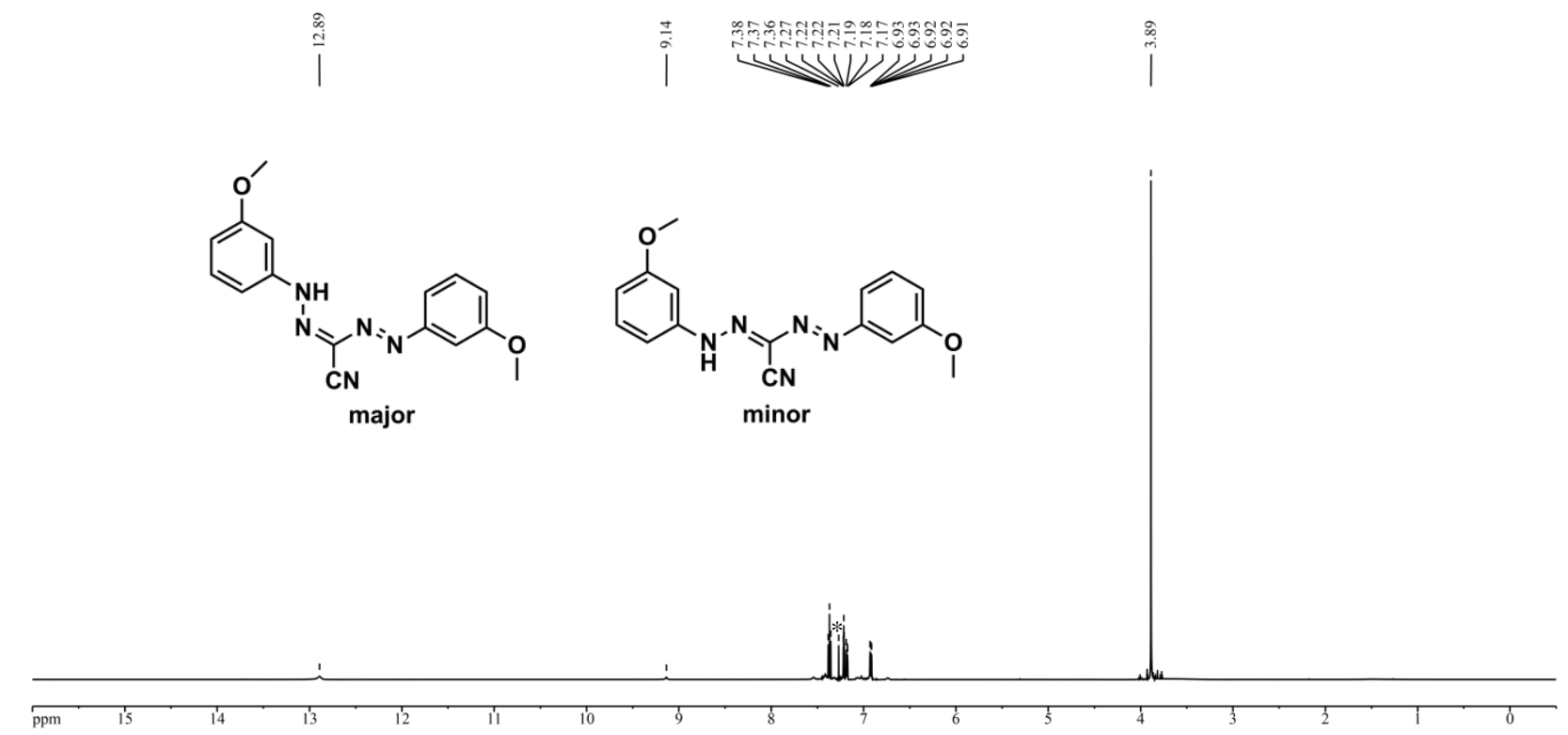

Figure S5. ${ }^{1} \mathrm{H}$ NMR spectrum of $\mathbf{4 b}$ in $\mathrm{CDCl}_{3}$. The asterisk denotes residual solvent signal.

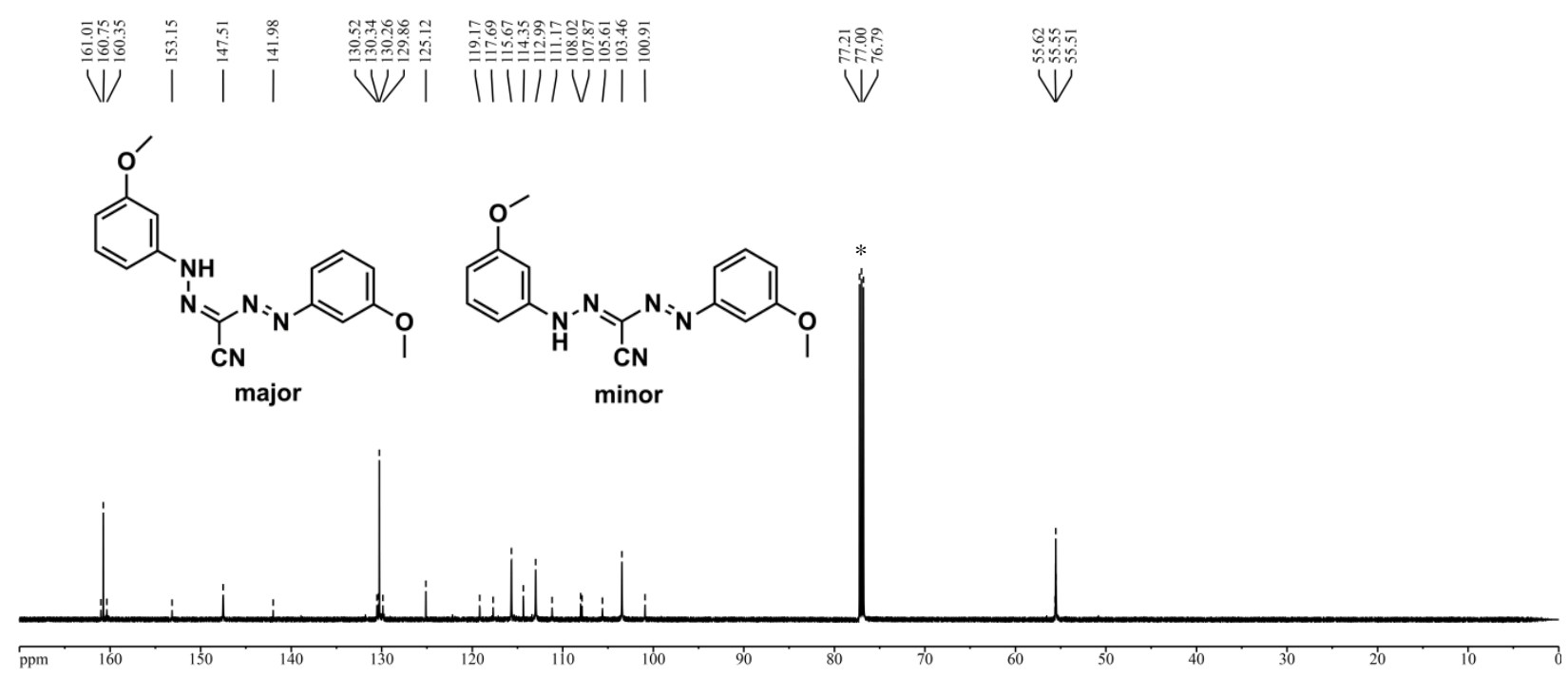

Figure S6. ${ }^{13} \mathrm{C}\left\{{ }^{1} \mathrm{H}\right\}$ NMR spectrum of $\mathbf{4 b}$ in $\mathrm{CDCl}_{3}$. The asterisk denotes solvent signal. 


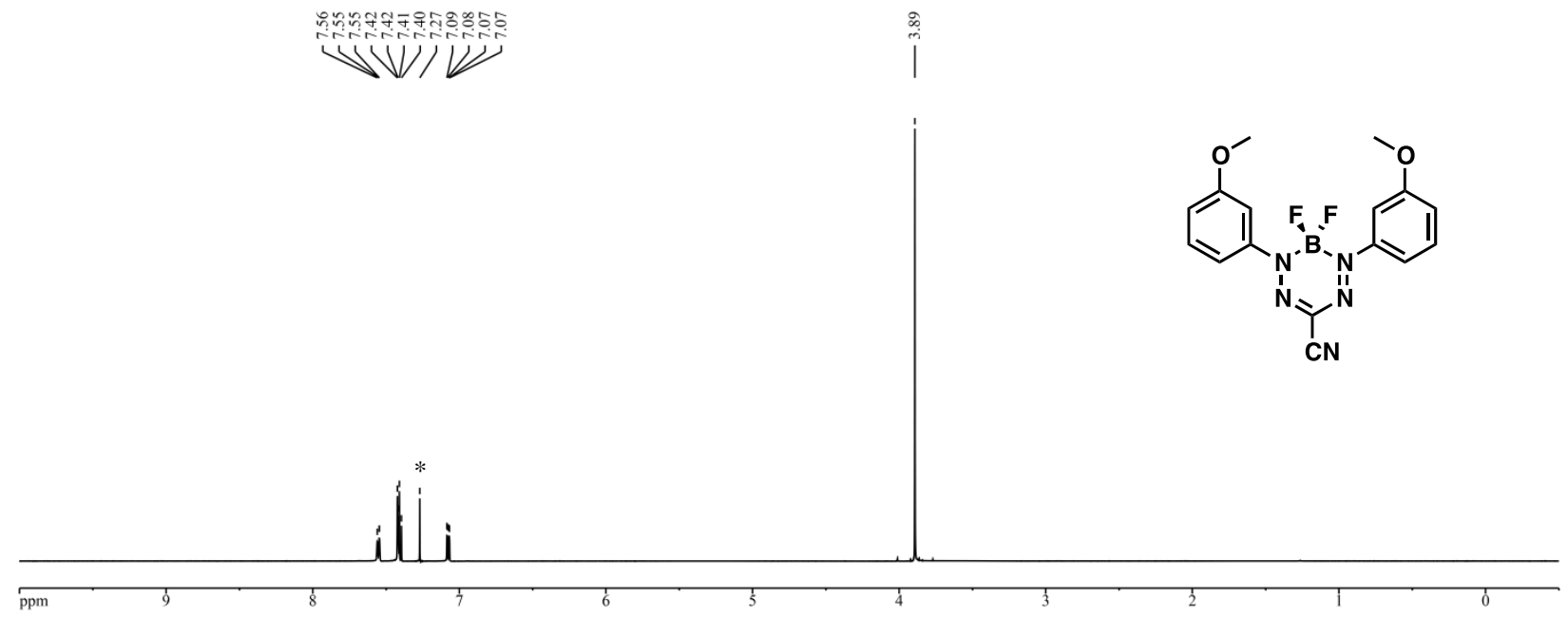

Figure S7. ${ }^{1} \mathrm{H}$ NMR spectrum of $\mathbf{7 b}$ in $\mathrm{CDCl}_{3}$. The asterisk denotes residual solvent signal.

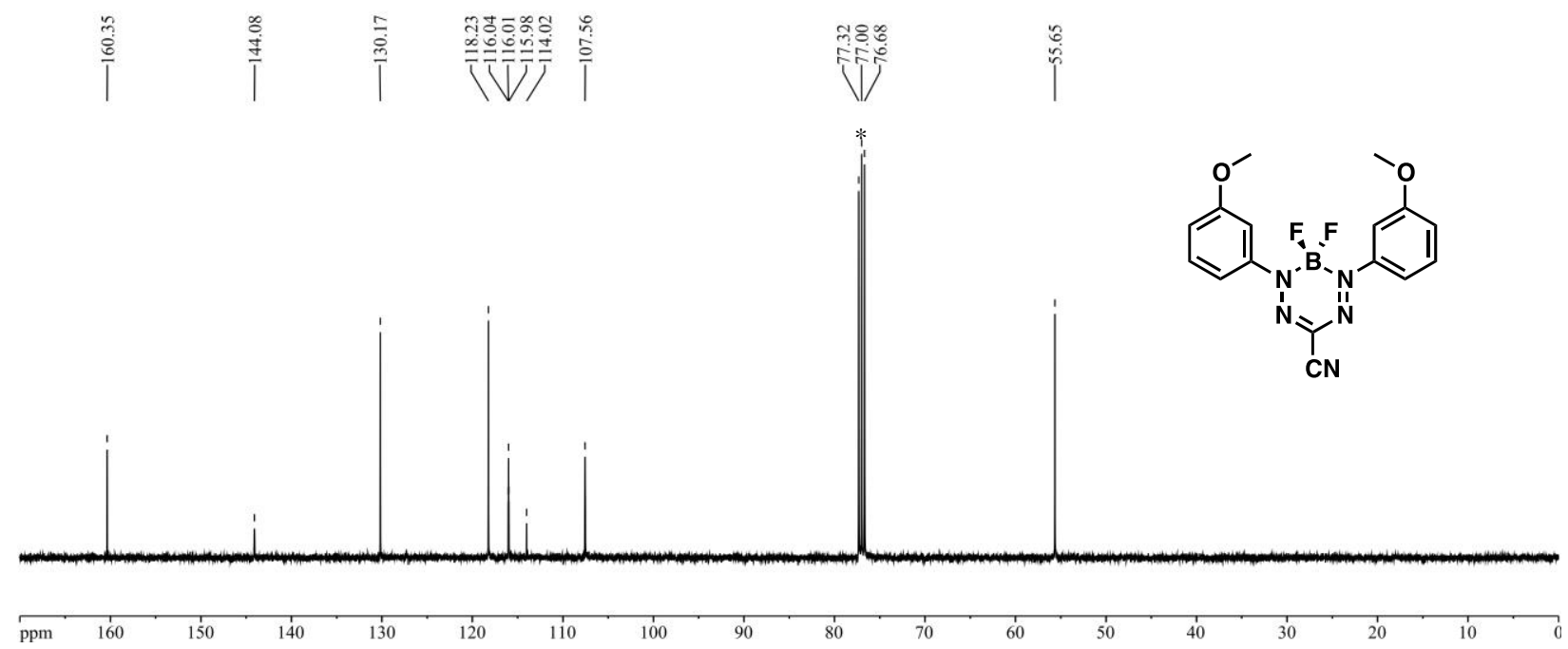

Figure S8. ${ }^{13} \mathrm{C}\left\{{ }^{1} \mathrm{H}\right\}$ NMR spectrum of $\mathbf{7 b}$ in $\mathrm{CDCl}_{3}$. The asterisk denotes solvent signal. 


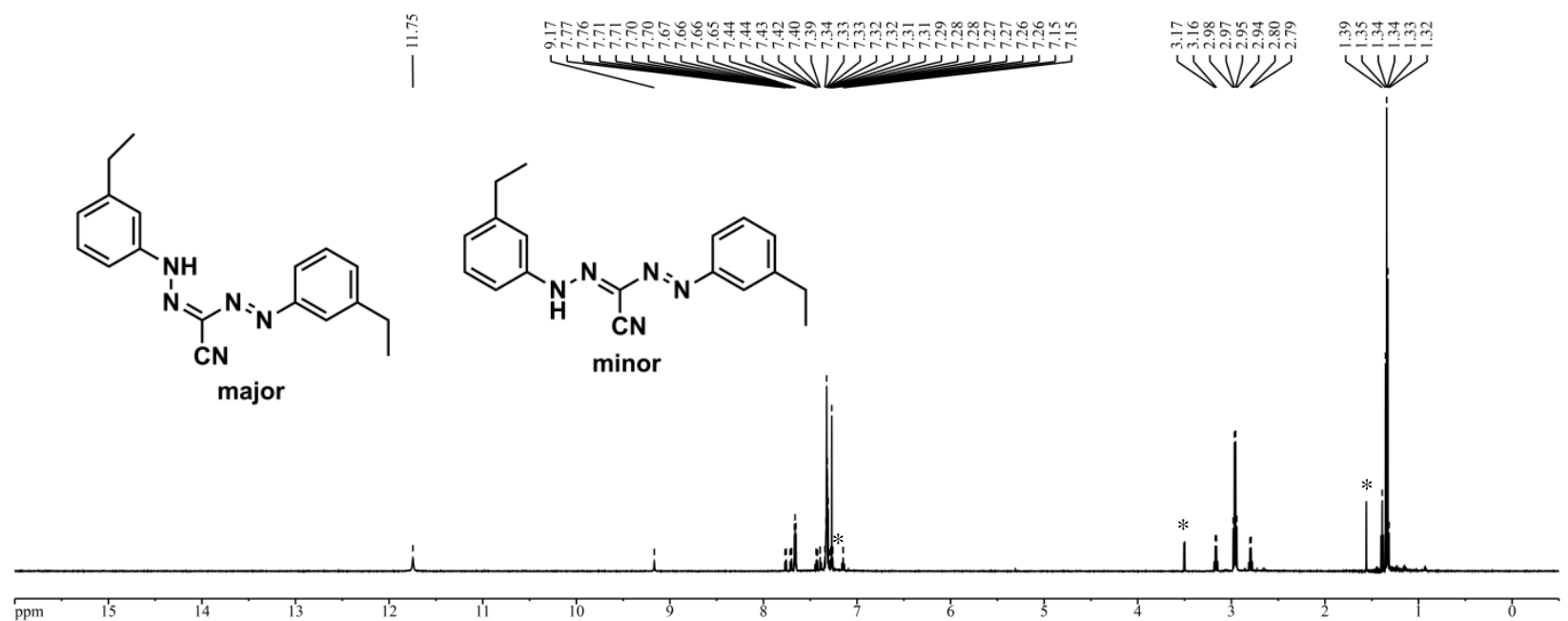

Figure S9. ${ }^{1} \mathrm{H} \mathrm{NMR}$ spectrum of $\mathbf{4 d}$ in $\mathrm{CDCl}_{3}$. The asterisks denote residual solvent signals.

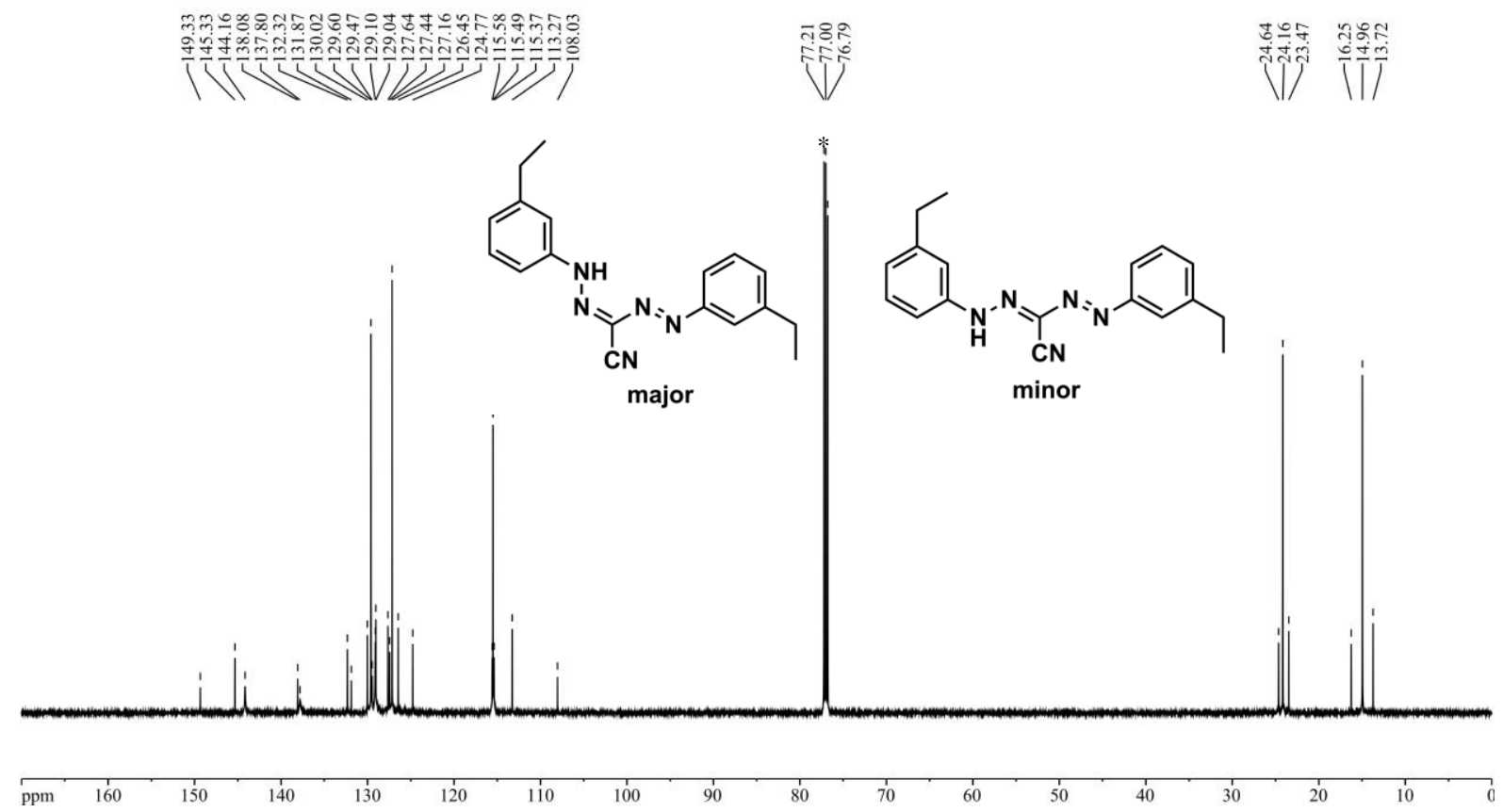

Figure S10. ${ }^{13} \mathrm{C}\left\{{ }^{1} \mathrm{H}\right\}$ NMR spectrum of $\mathbf{4 d}$ in $\mathrm{CDCl}_{3}$. The asterisk denotes solvent signal. 


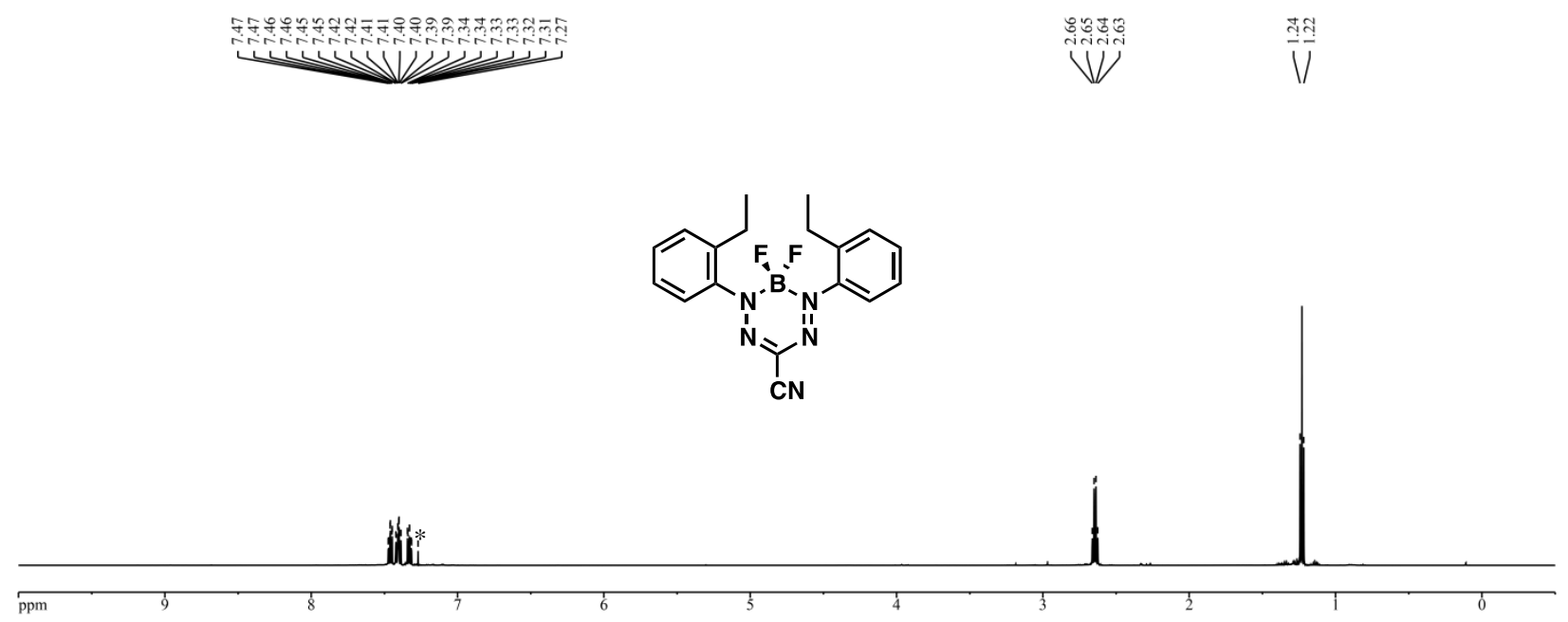

Figure S11. ${ }^{1} \mathrm{H}$ NMR spectrum of $\mathbf{7 d}$ in $\mathrm{CDCl}_{3}$. The asterisk denotes residual solvent signal.

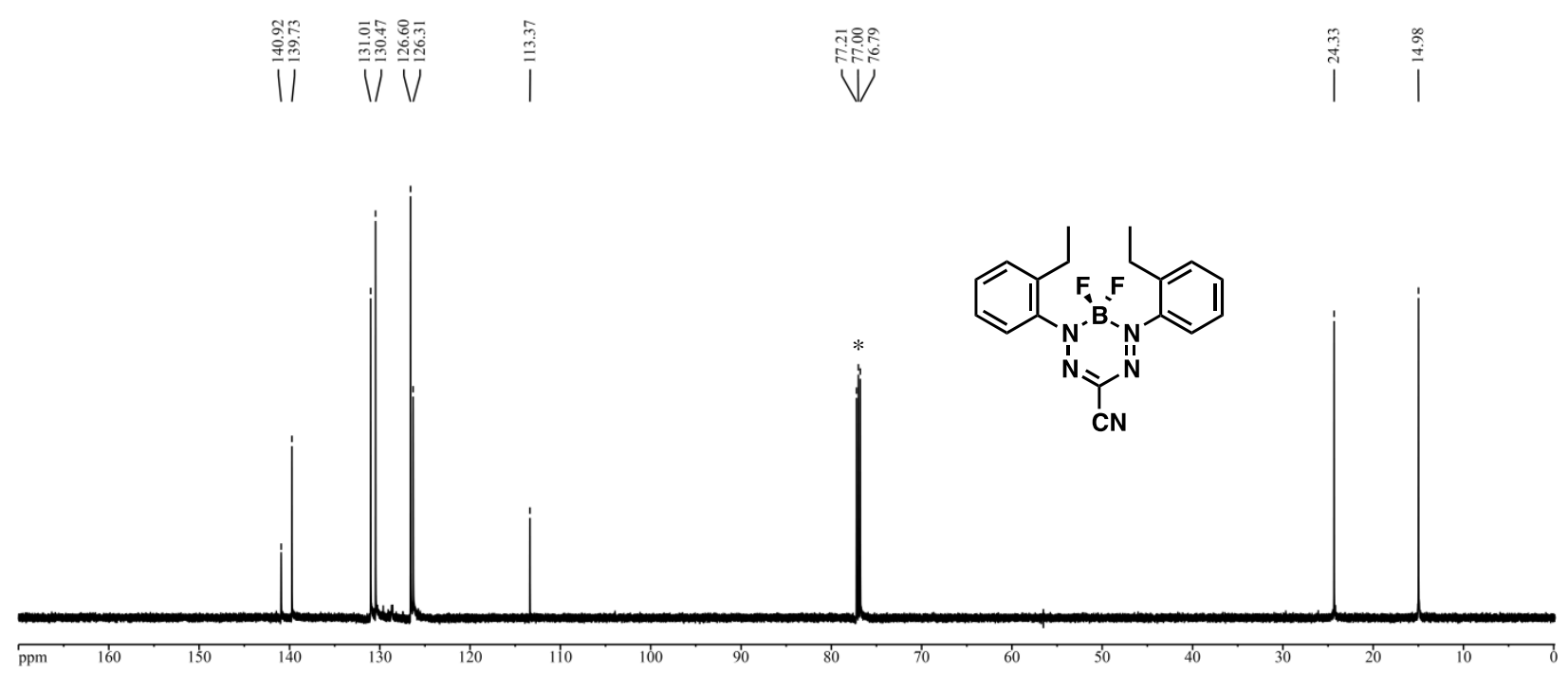

Figure S12. ${ }^{13} \mathrm{C}\left\{{ }^{1} \mathrm{H}\right\}$ NMR spectrum of $\mathbf{7 d}$ in $\mathrm{CDCl}_{3}$. The asterisk denotes solvent signal. 


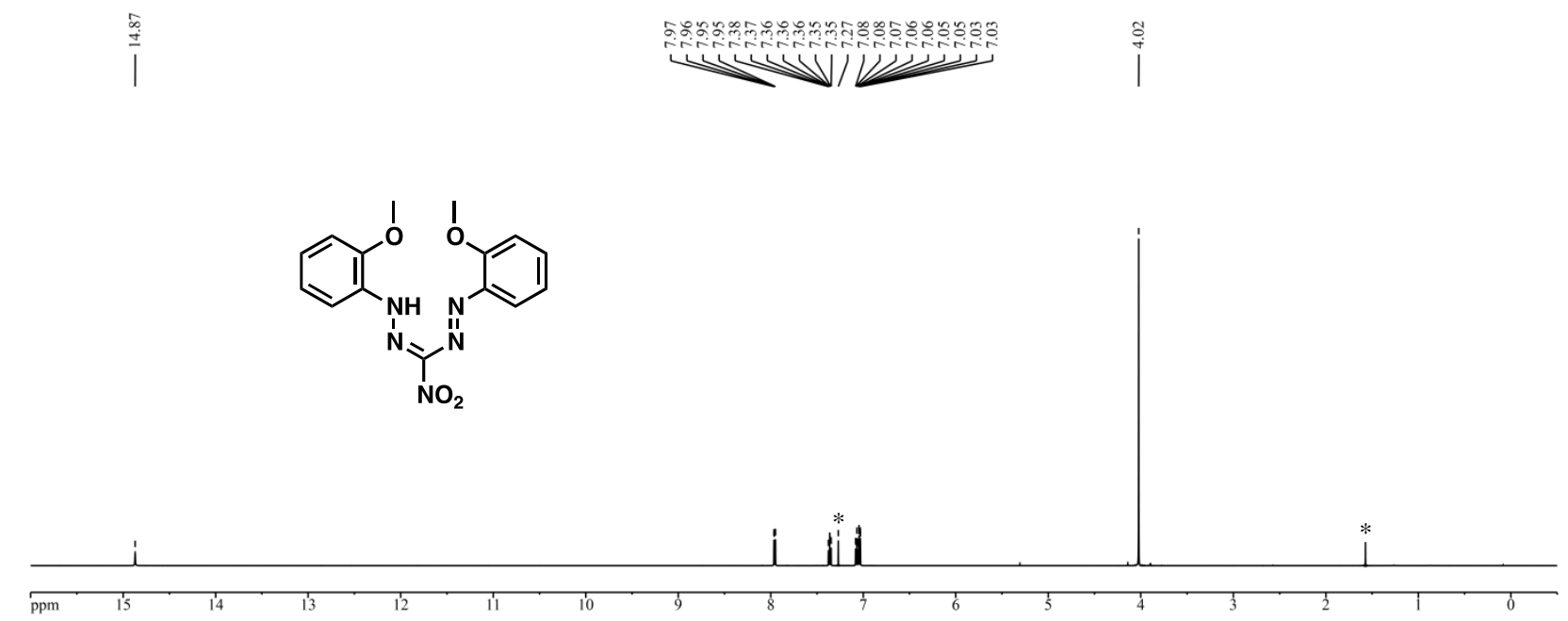

Figure S13. ${ }^{1} \mathrm{H}$ NMR spectrum of $\mathbf{5 a}$ in $\mathrm{CDCl}_{3}$. The asterisks denote residual solvent signals.

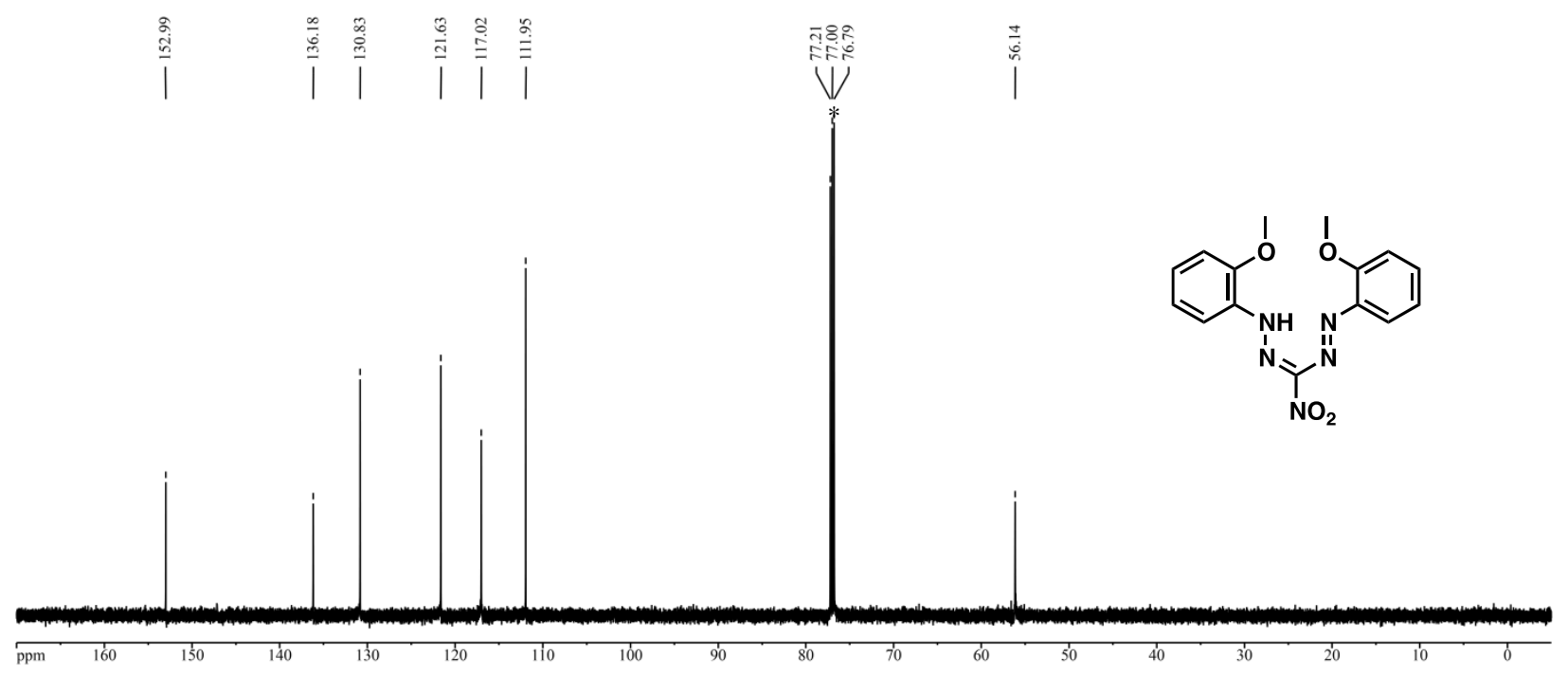

Figure S14. ${ }^{13} \mathrm{C}\left\{{ }^{1} \mathrm{H}\right\}$ NMR spectrum of $\mathbf{5 a}$ in $\mathrm{CDCl}_{3}$. The asterisk denotes solvent signal. 


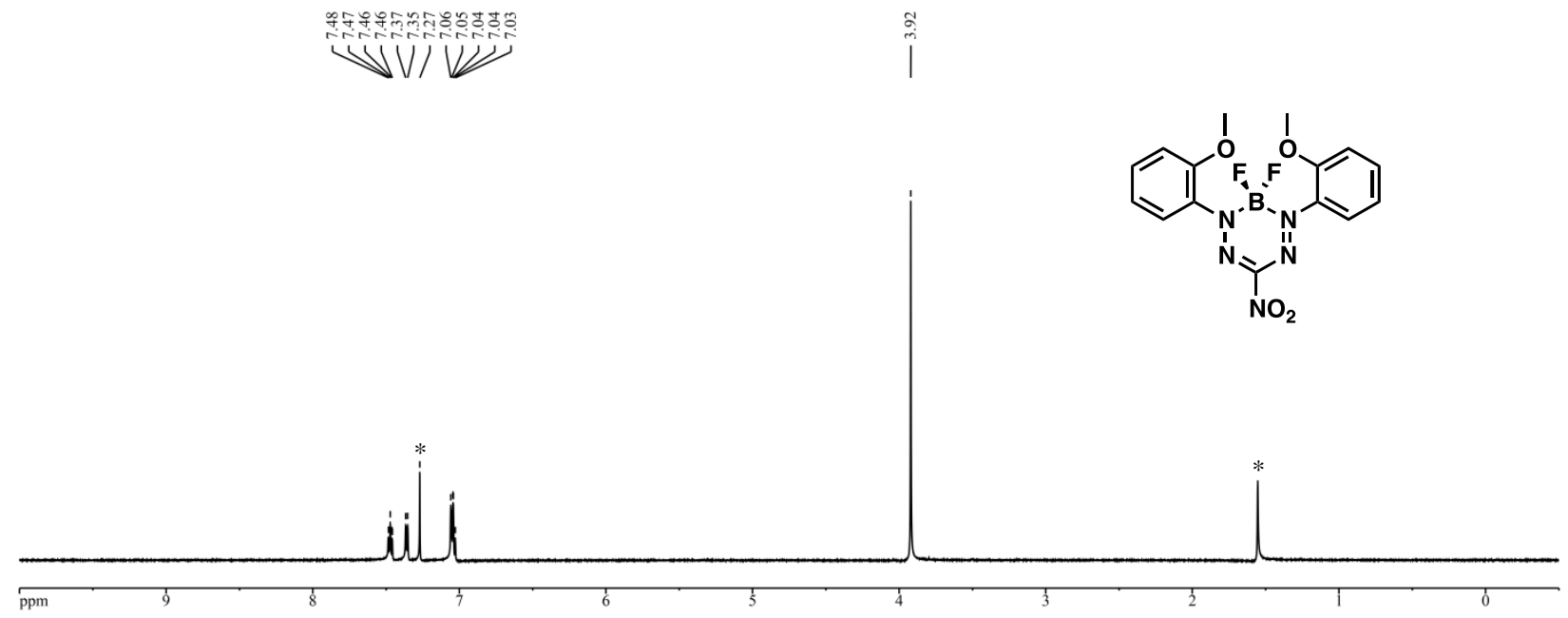

Figure S15. ${ }^{1} \mathrm{H}$ NMR spectrum of $\mathbf{8 a}$ in $\mathrm{CDCl}_{3}$. The asterisks denote residual solvent signals.

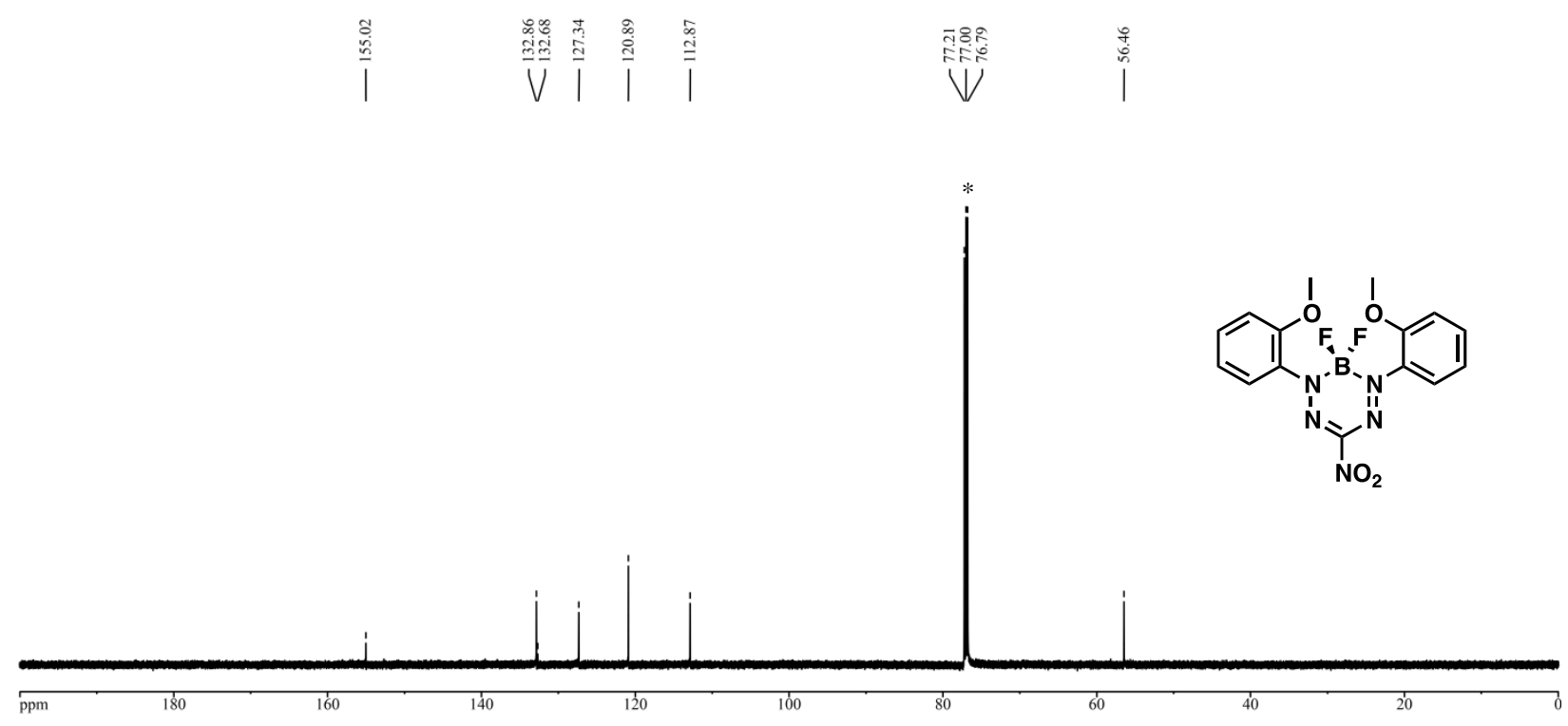

Figure S16. ${ }^{13} \mathrm{C}\left\{{ }^{1} \mathrm{H}\right\}$ NMR spectrum of $\mathbf{8 a}$ in $\mathrm{CDCl}_{3}$. The asterisk denotes solvent signal. 


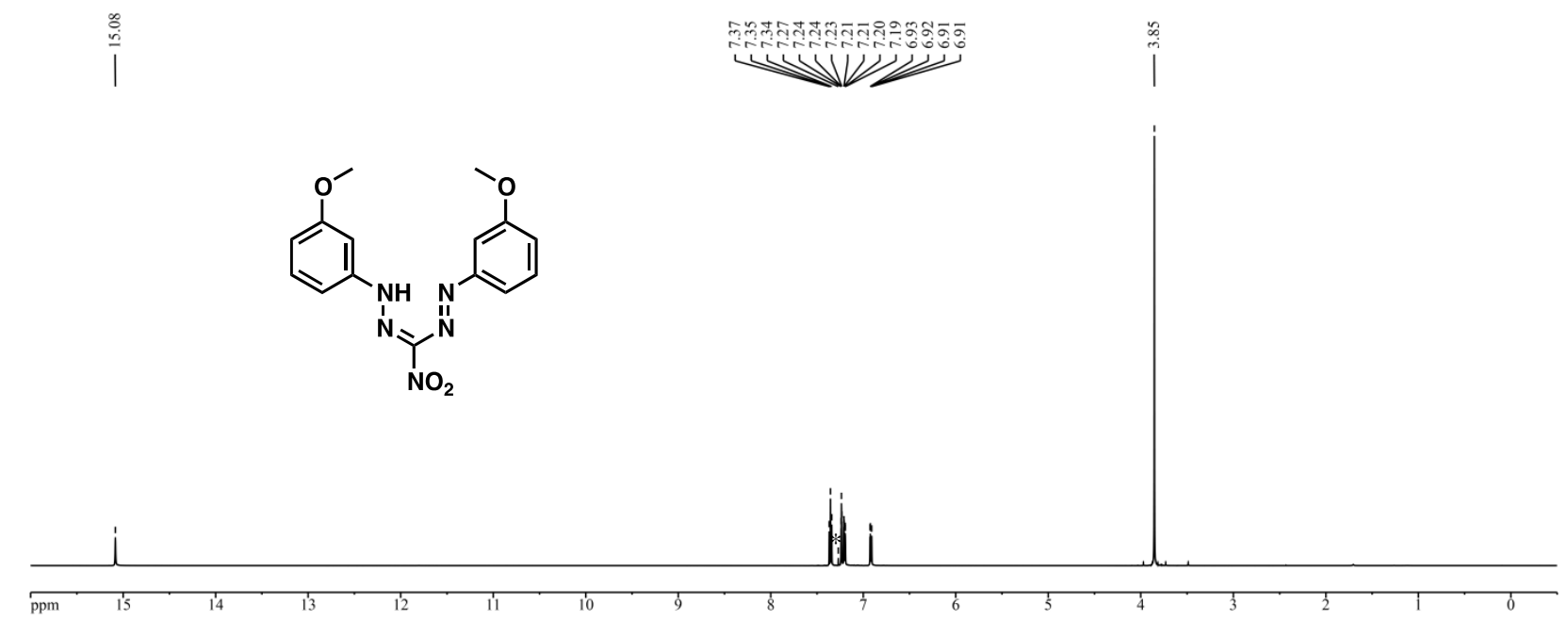

Figure S17. ${ }^{1} \mathrm{H}$ NMR spectrum of $\mathbf{5 b}$ in $\mathrm{CDCl}_{3}$. The asterisk denotes residual solvent signal.

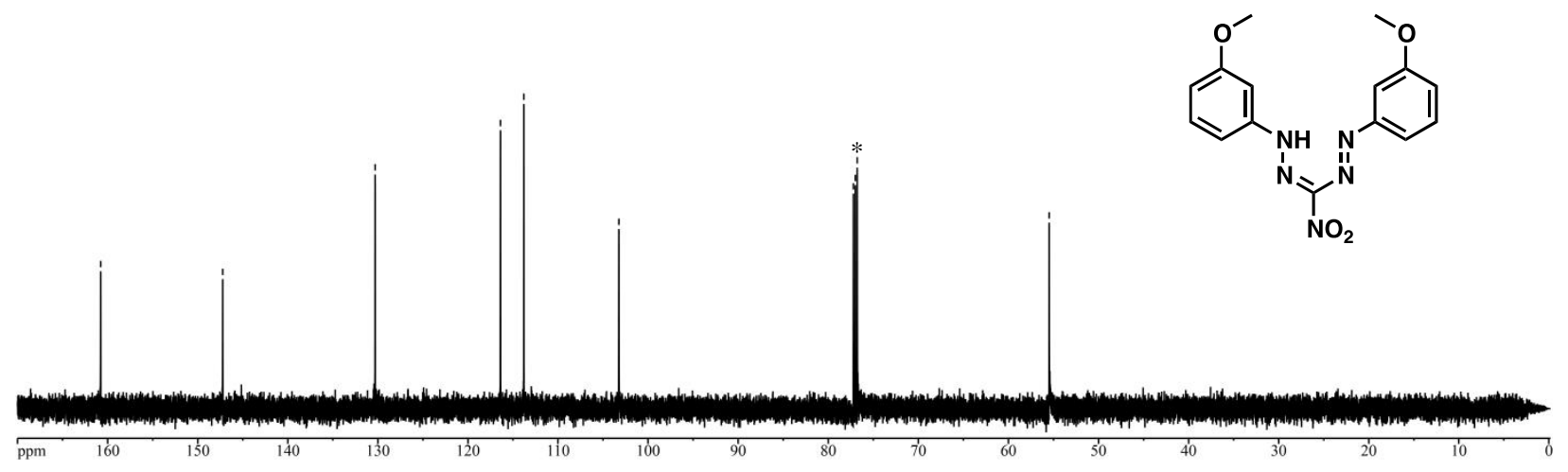

Figure S18. ${ }^{13} \mathrm{C}\left\{{ }^{1} \mathrm{H}\right\}$ NMR spectrum of $\mathbf{5 b}$ in $\mathrm{CDCl}_{3}$. The asterisk denotes solvent signal. 


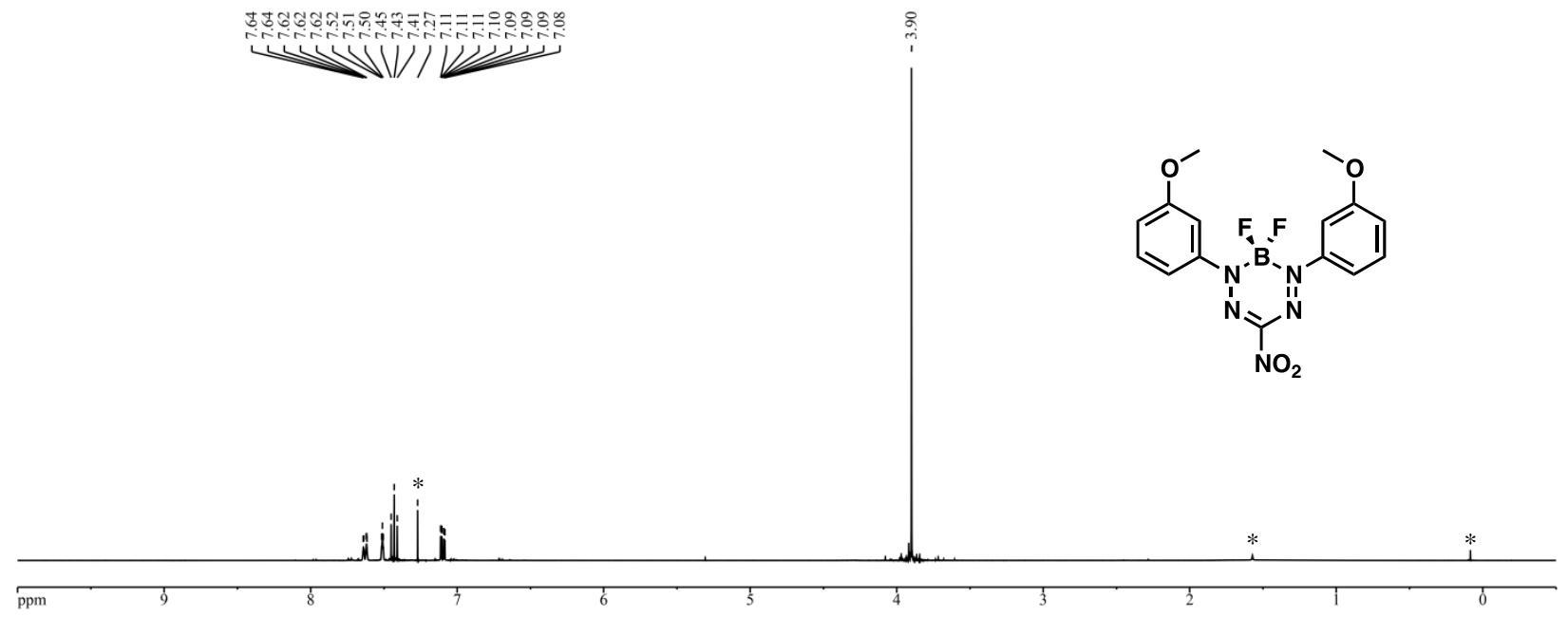

Figure S19. ${ }^{1} \mathrm{H}$ NMR spectrum of $\mathbf{8 b}$ in $\mathrm{CDCl}_{3}$. The asterisks denote residual solvent signals.

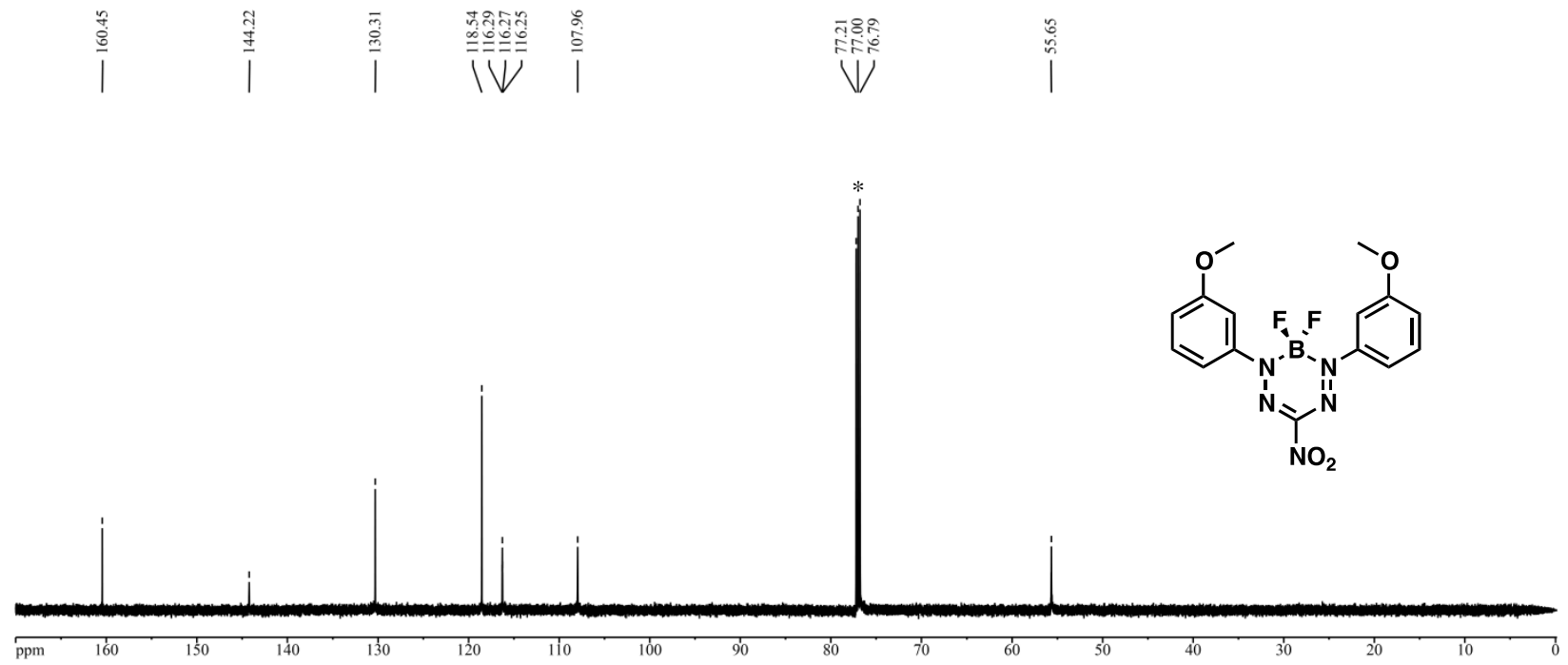

Figure S20. ${ }^{13} \mathrm{C}\left\{{ }^{1} \mathrm{H}\right\}$ NMR spectrum of $\mathbf{8 b}$ in $\mathrm{CDCl}_{3}$. The asterisk denotes solvent signal. 


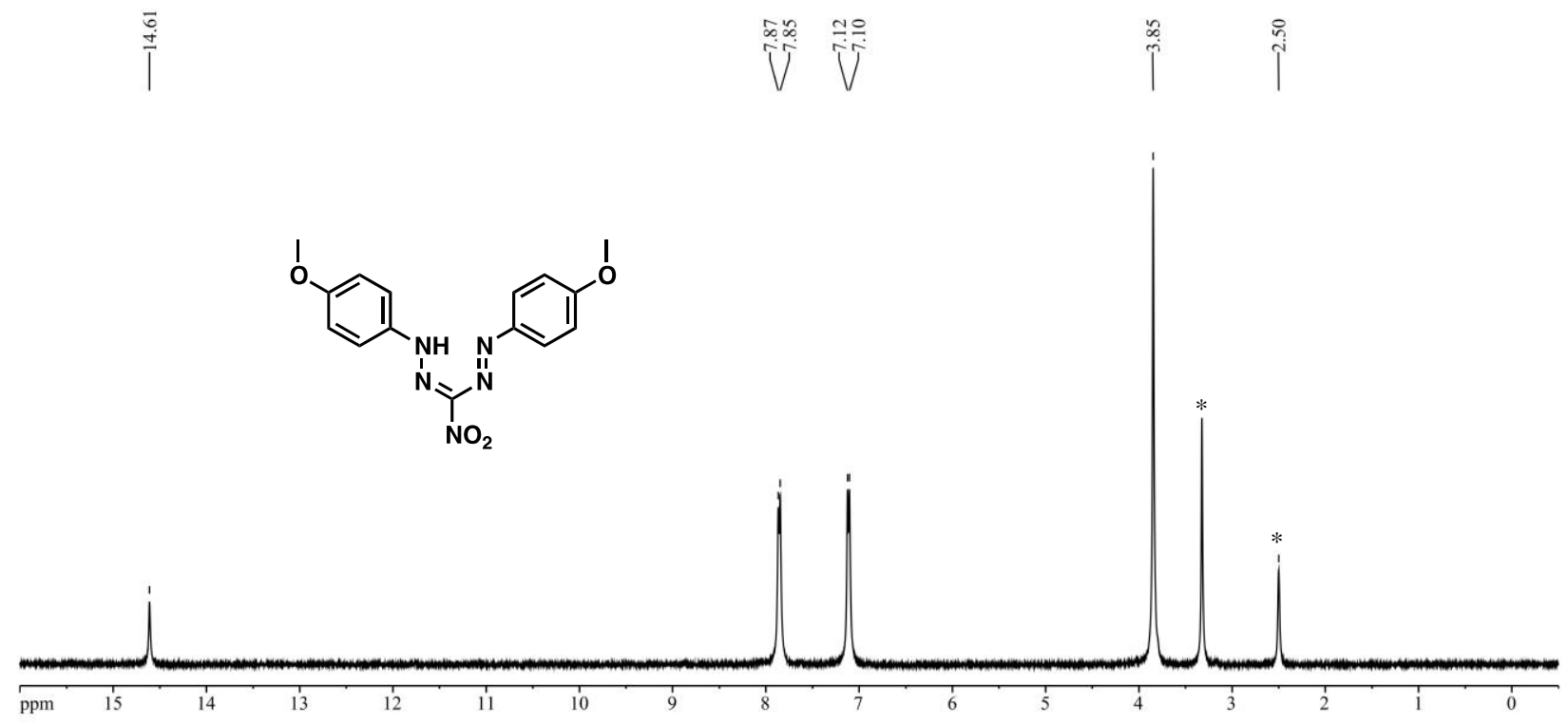

Figure S21. ${ }^{1} \mathrm{H}$ NMR spectrum of $\mathbf{5 c}$ in DMSO- $d_{6}$. The asterisks denote residual solvent signals.

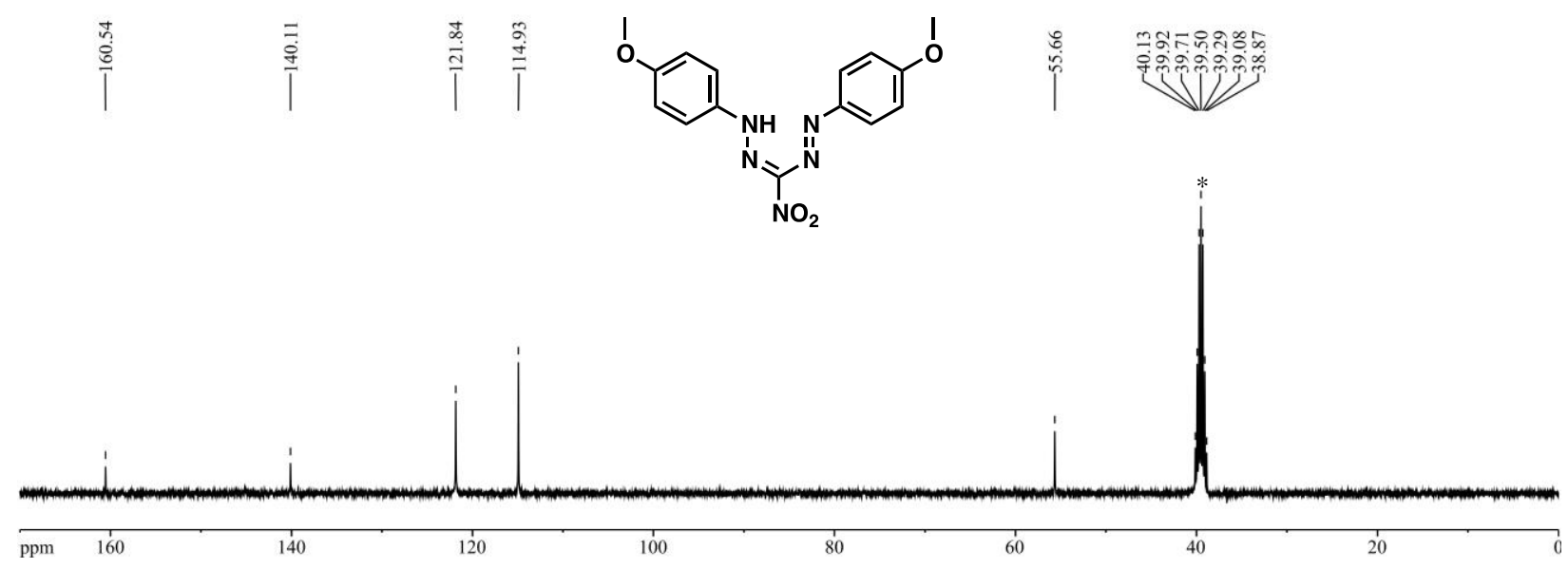

Figure S22. ${ }^{13} \mathrm{C}\left\{{ }^{1} \mathrm{H}\right\}$ NMR spectrum of $\mathbf{5 c}$ in DMSO- $d_{6}$. The asterisk denotes solvent signal. 


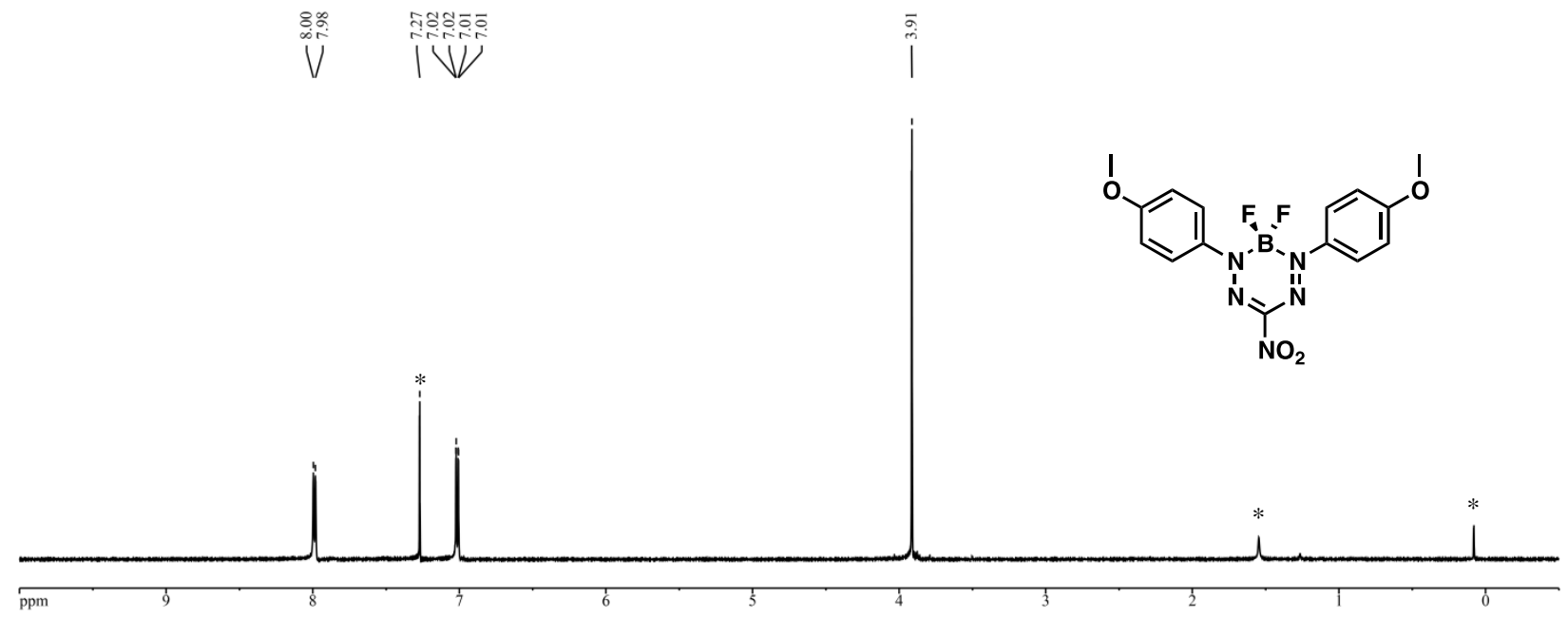

Figure S23. ${ }^{1} \mathrm{H}$ NMR spectrum of $\mathbf{8 c}$ in $\mathrm{CDCl}_{3}$. The asterisks denote residual solvent signals.

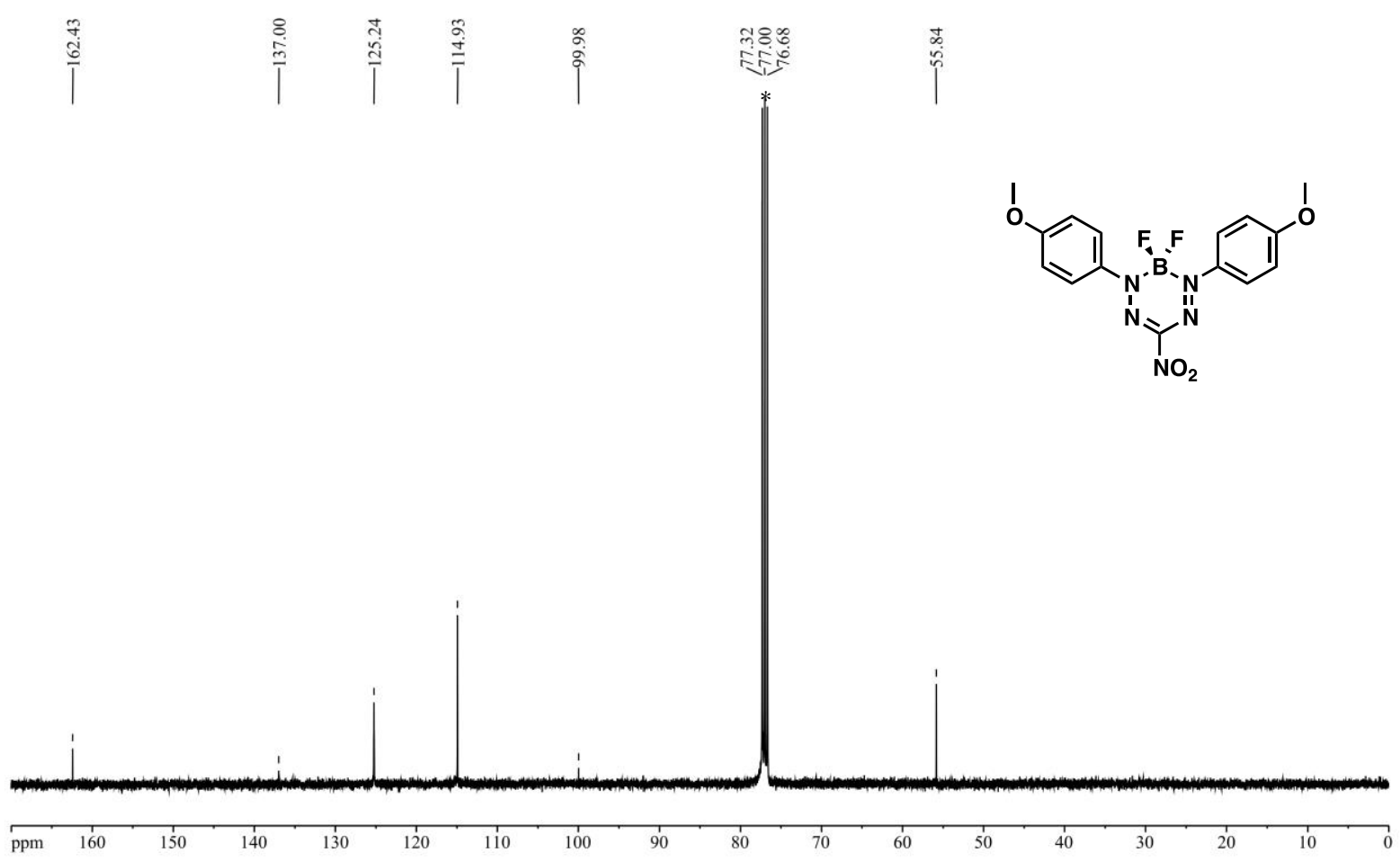

Figure S24. ${ }^{13} \mathrm{C}\left\{{ }^{1} \mathrm{H}\right\}$ NMR spectrum of $\mathbf{8 c}$ in $\mathrm{CDCl}_{3}$. The asterisk denotes solvent signal. 


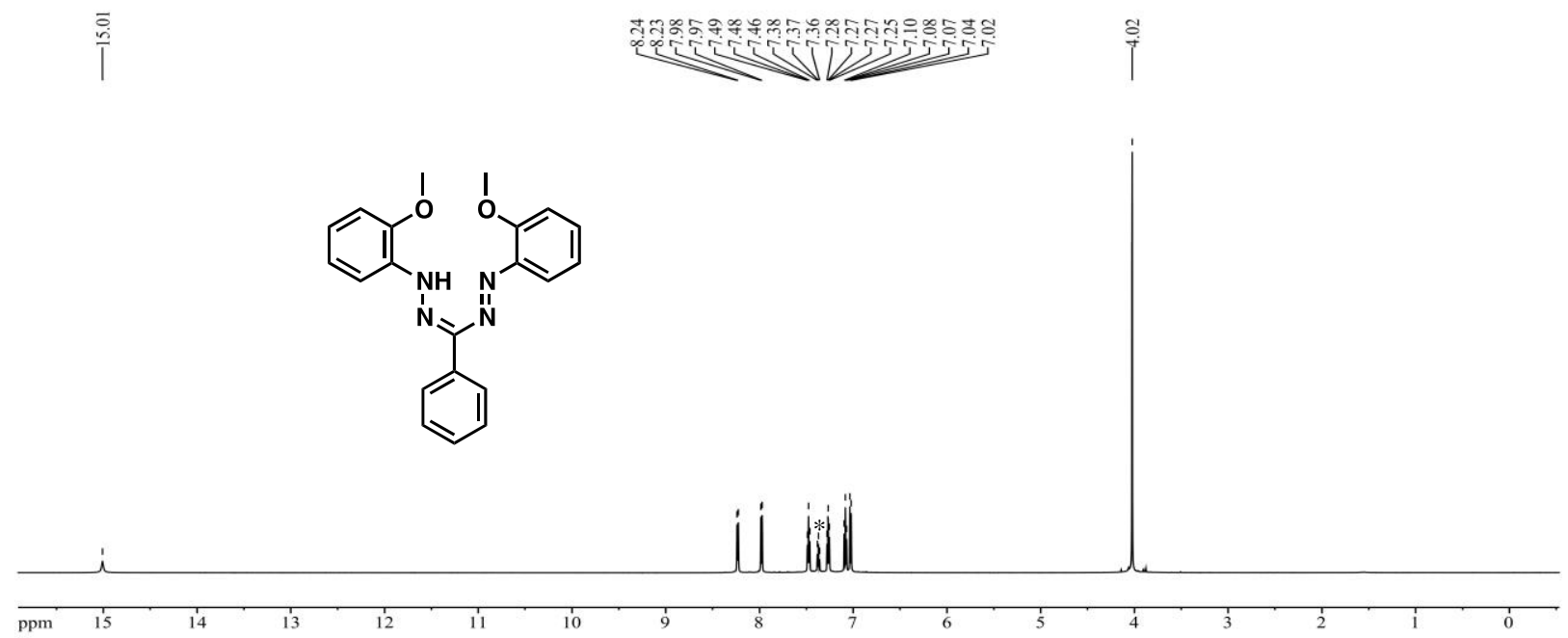

Figure S25. ${ }^{1} \mathrm{H}$ NMR spectrum of $\mathbf{6 a}$ in $\mathrm{CDCl}_{3}$. The asterisk denotes residual solvent signal.

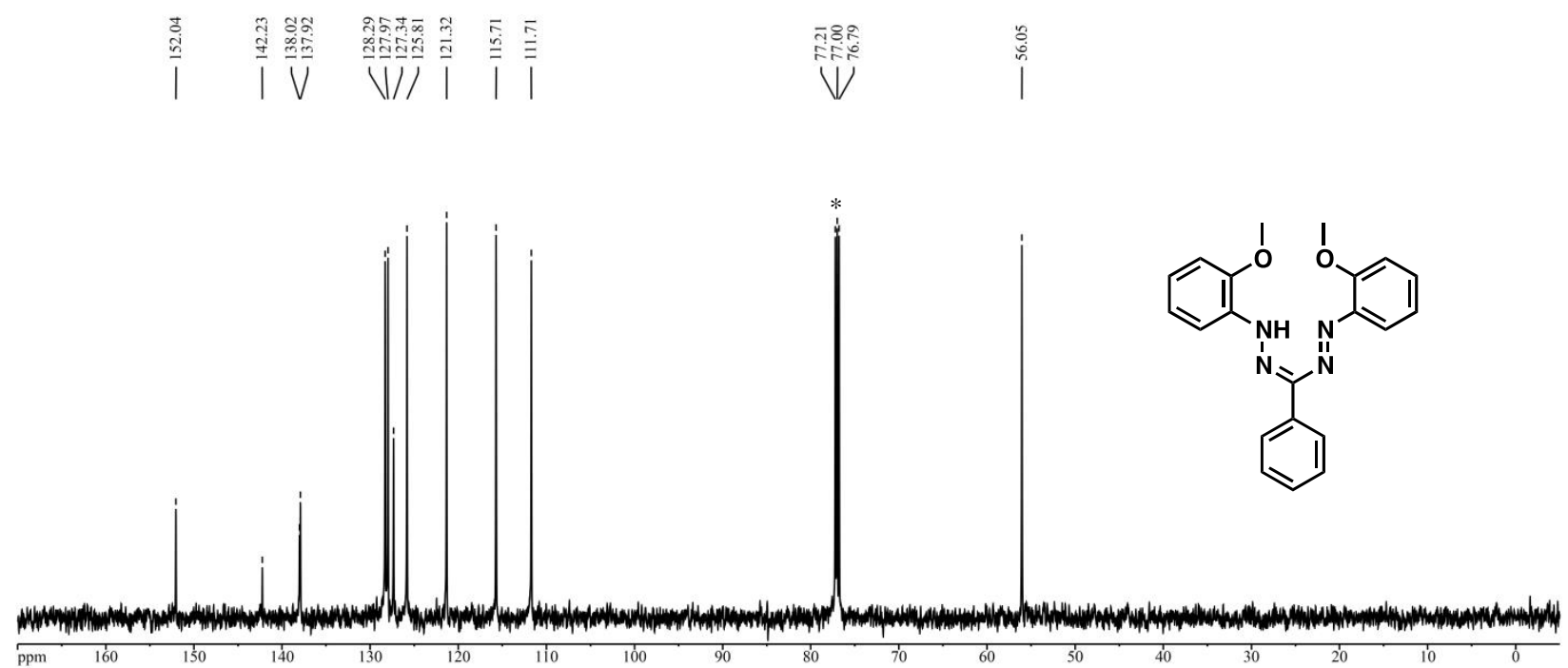

Figure S26. ${ }^{13} \mathrm{C}\left\{{ }^{1} \mathrm{H}\right\}$ NMR spectrum of $\mathbf{6 a}$ in $\mathrm{CDCl}_{3}$. The asterisk denotes solvent signal. 


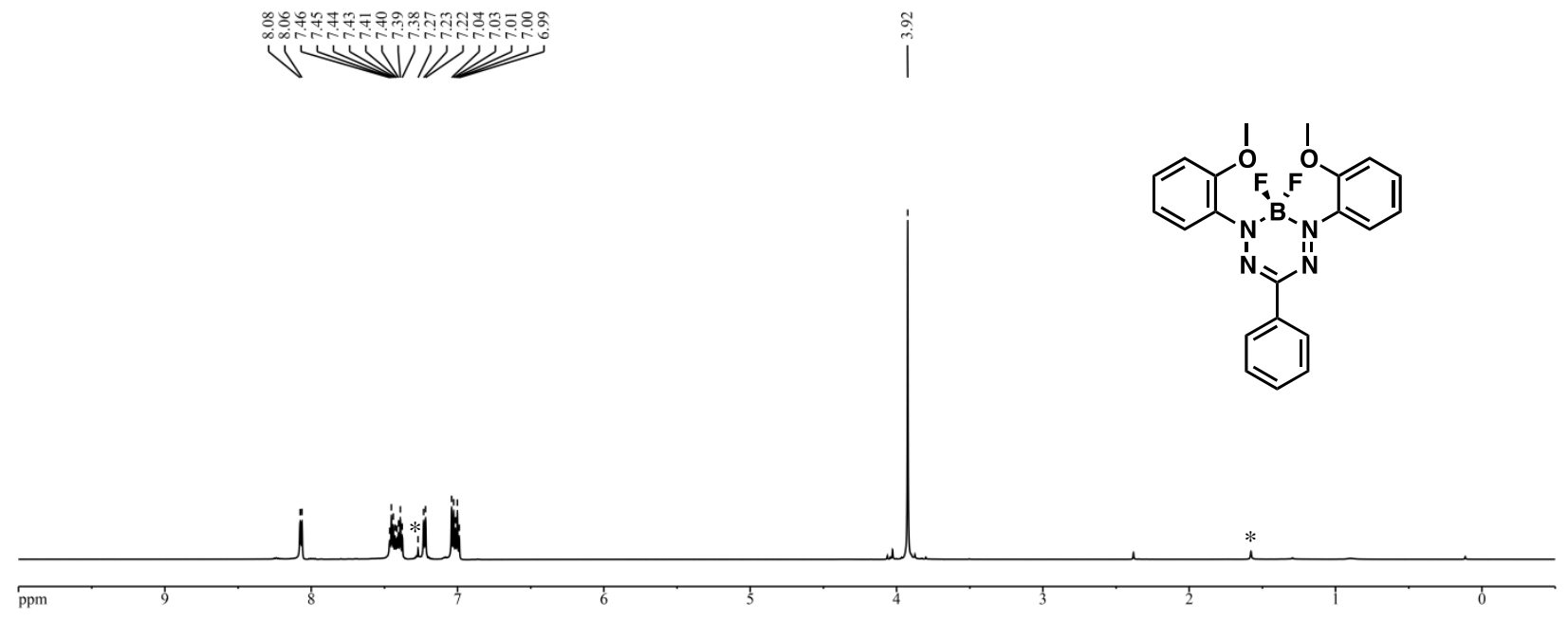

Figure S27. ${ }^{1} \mathrm{H}$ NMR spectrum of $\mathbf{9 a}$ in $\mathrm{CDCl}_{3}$. The asterisks denote residual solvent signals.
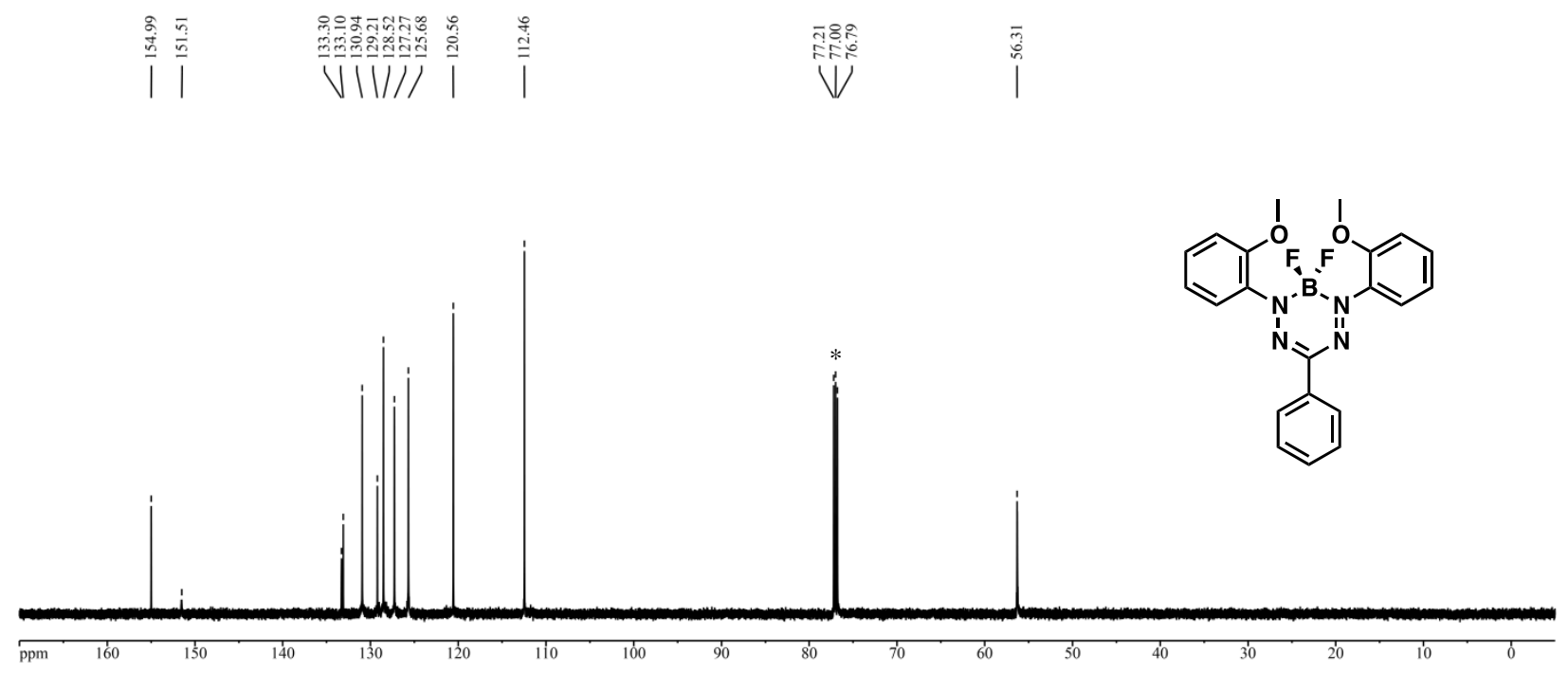

Figure S28. ${ }^{13} \mathrm{C}\left\{{ }^{1} \mathrm{H}\right\}$ NMR spectrum of $9 \mathbf{a}$ in $\mathrm{CDCl}_{3}$. The asterisk denotes solvent signal. 


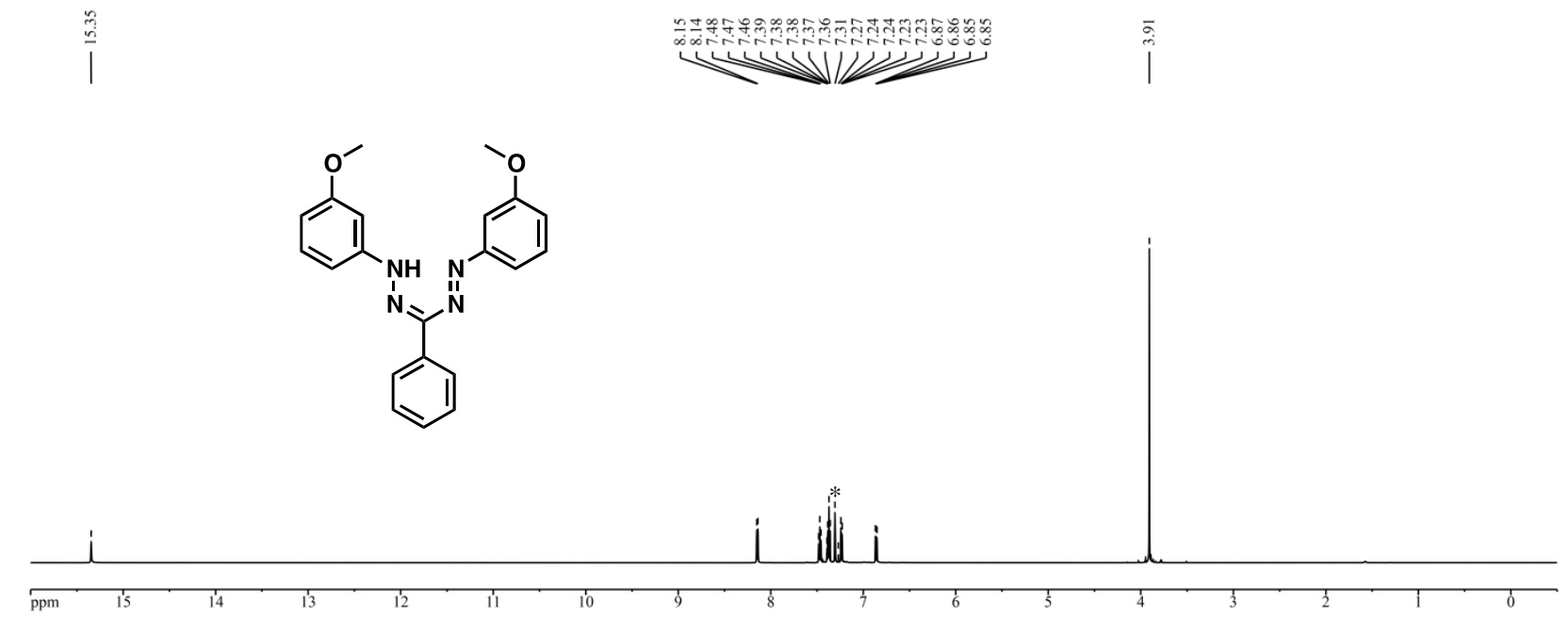

Figure S29. ${ }^{1} \mathrm{H} \mathrm{NMR}$ spectrum of $\mathbf{6 b}$ in $\mathrm{CDCl}_{3}$. The asterisk denotes residual solvent signal.

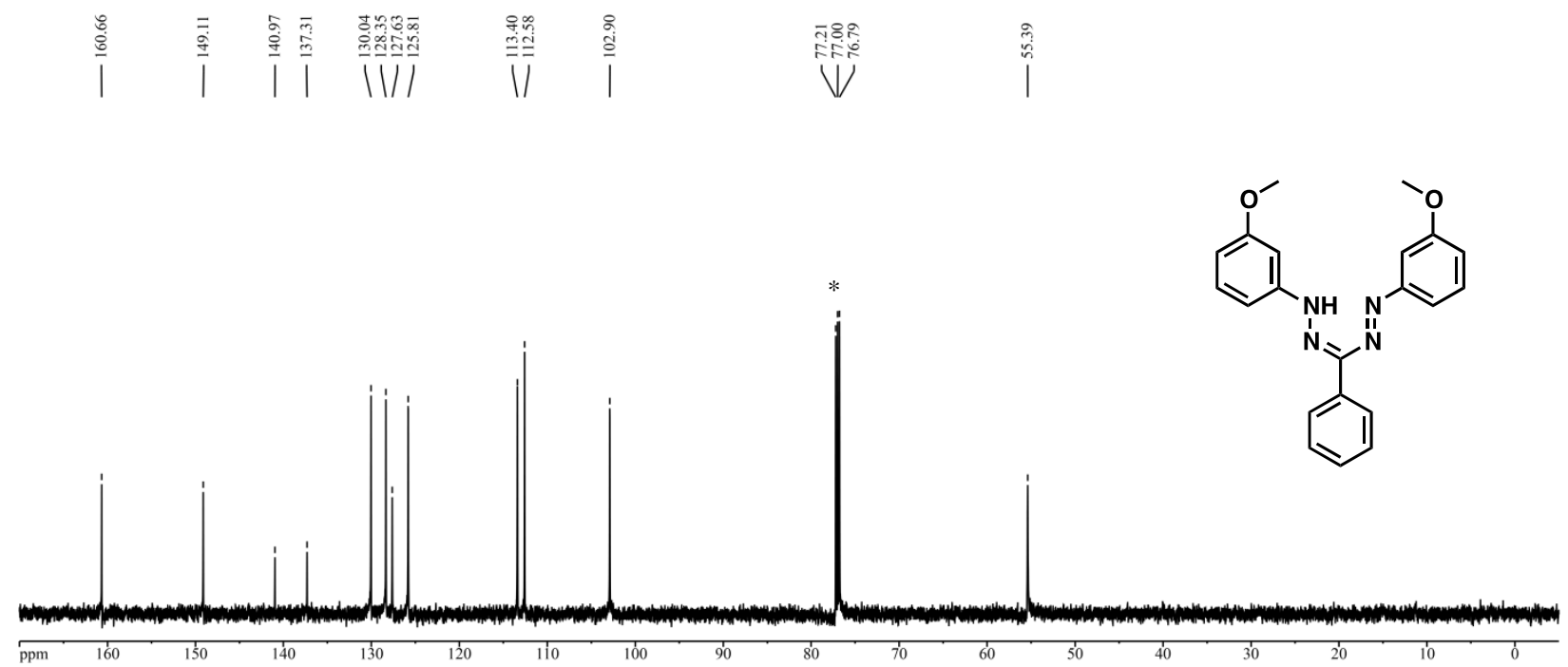

Figure S30. ${ }^{13} \mathrm{C}\left\{{ }^{1} \mathrm{H}\right\}$ NMR spectrum of $\mathbf{6 b}$ in $\mathrm{CDCl}_{3}$. The asterisk denotes solvent signal. 


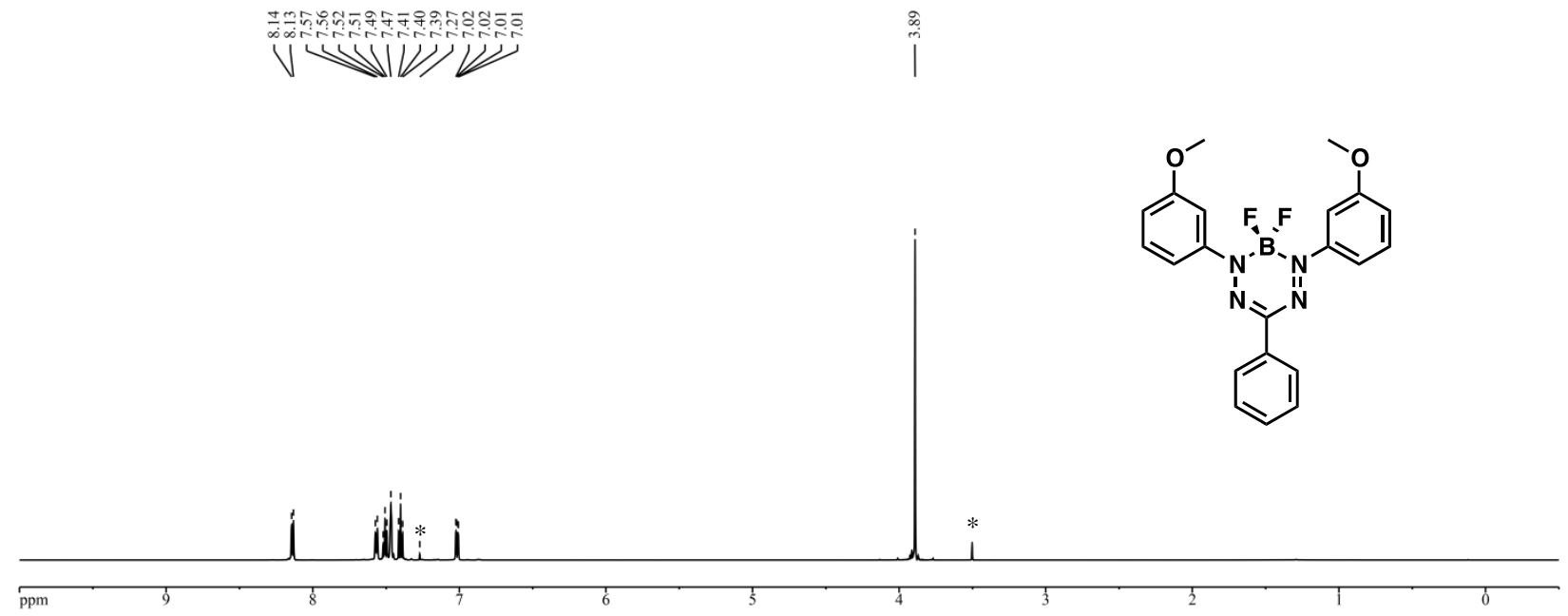

Figure S31. ${ }^{1} \mathrm{H}$ NMR spectrum of $\mathbf{9 b}$ in $\mathrm{CDCl}_{3}$. The asterisks denote residual solvent signals.

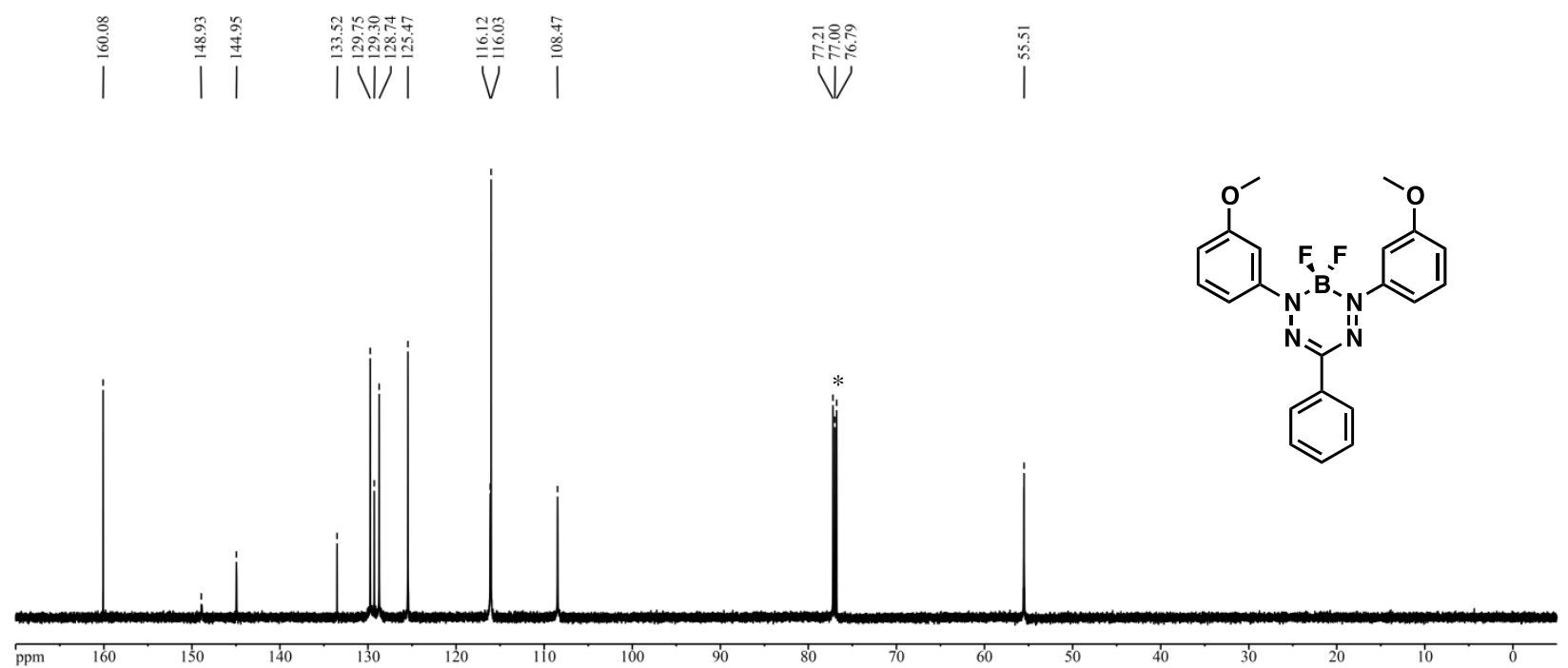

Figure S32. ${ }^{13} \mathrm{C}\left\{{ }^{1} \mathrm{H}\right\}$ NMR spectrum of $\mathbf{9 b}$ in $\mathrm{CDCl}_{3}$. The asterisk denotes solvent signal. 


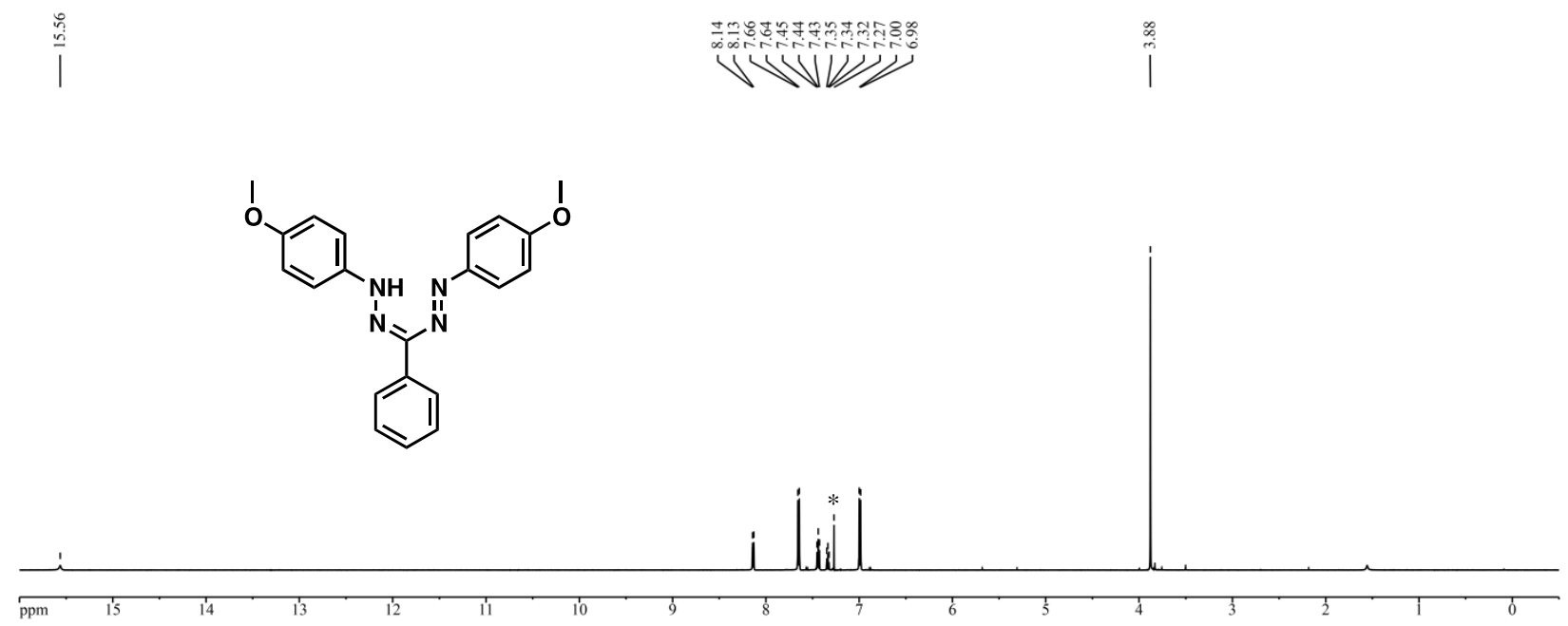

Figure S33. ${ }^{1} \mathrm{H}$ NMR spectrum of $\mathbf{6 c}$ in $\mathrm{CDCl}_{3}$. The asterisk denotes residual solvent signal.

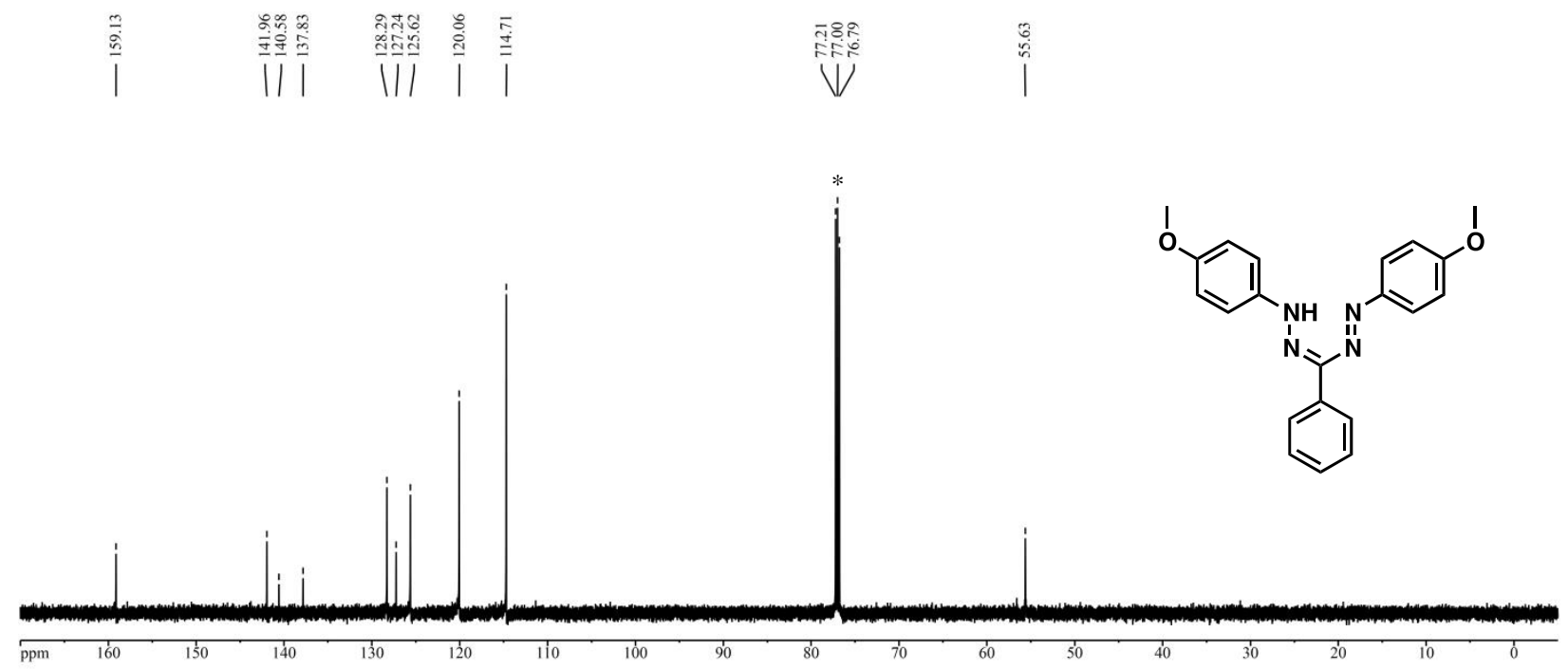

Figure S34. ${ }^{13} \mathrm{C}\left\{{ }^{1} \mathrm{H}\right\}$ NMR spectrum of $\mathbf{6 c}$ in $\mathrm{CDCl}_{3}$. The asterisk denotes solvent signal. 


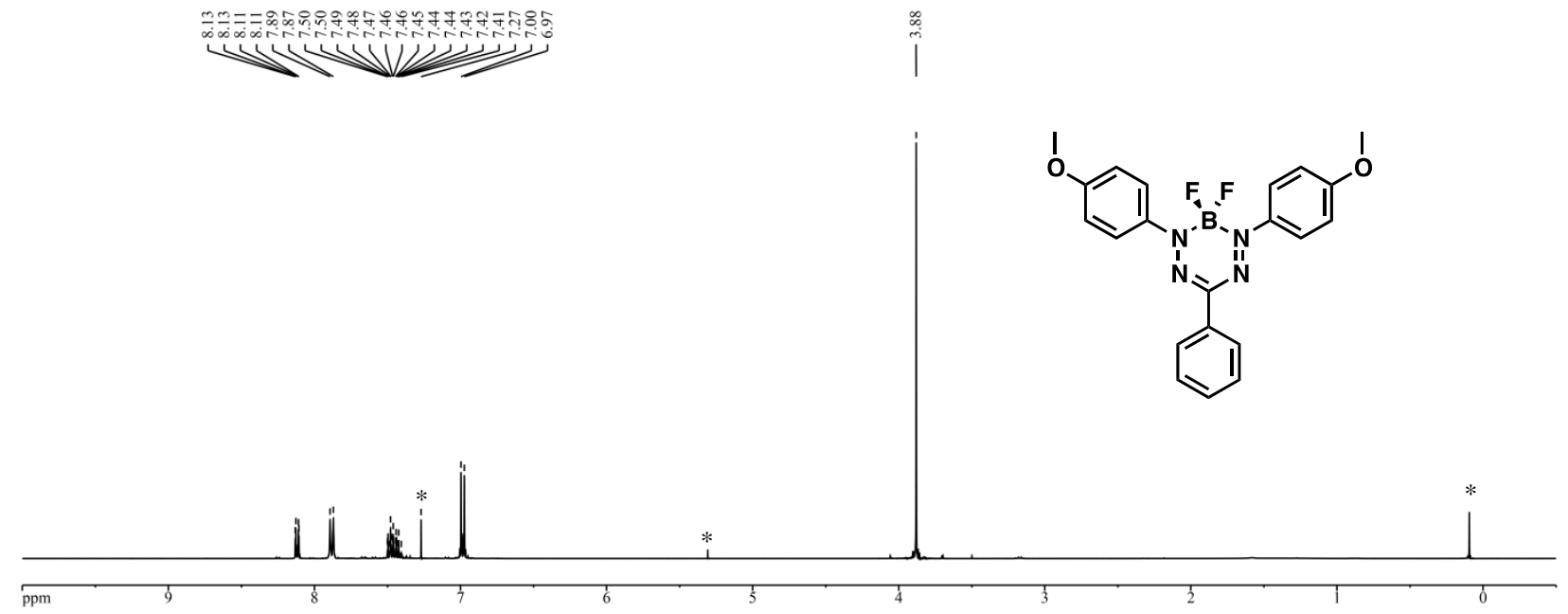

Figure S35. ${ }^{1} \mathrm{H}$ NMR spectrum of $9 \mathbf{c}$ in $\mathrm{CDCl}_{3}$. The asterisks denote residual solvent and grease signals.

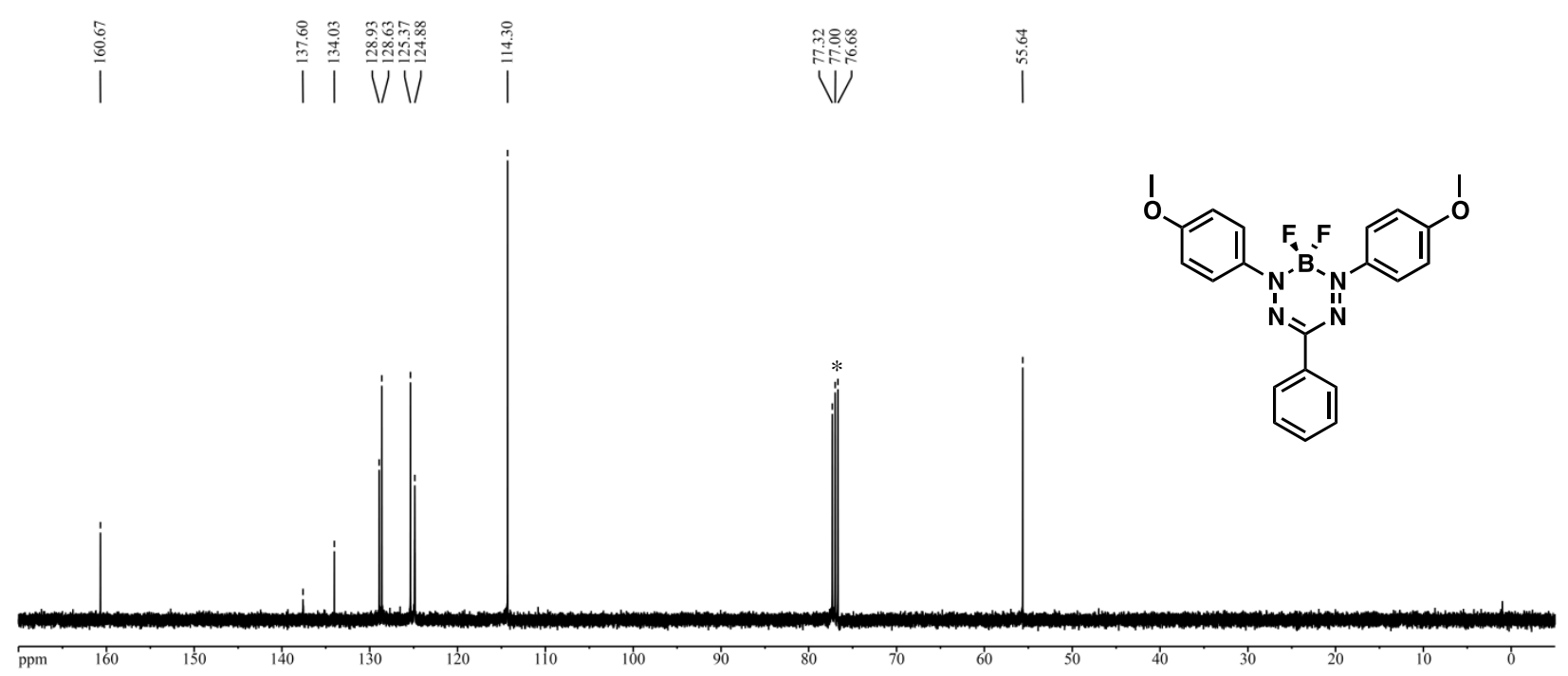

Figure S36. ${ }^{13} \mathrm{C}\left\{{ }^{1} \mathrm{H}\right\}$ NMR spectrum of $9 \mathrm{c}$ in $\mathrm{CDCl}_{3}$. The asterisk denotes solvent signal. 


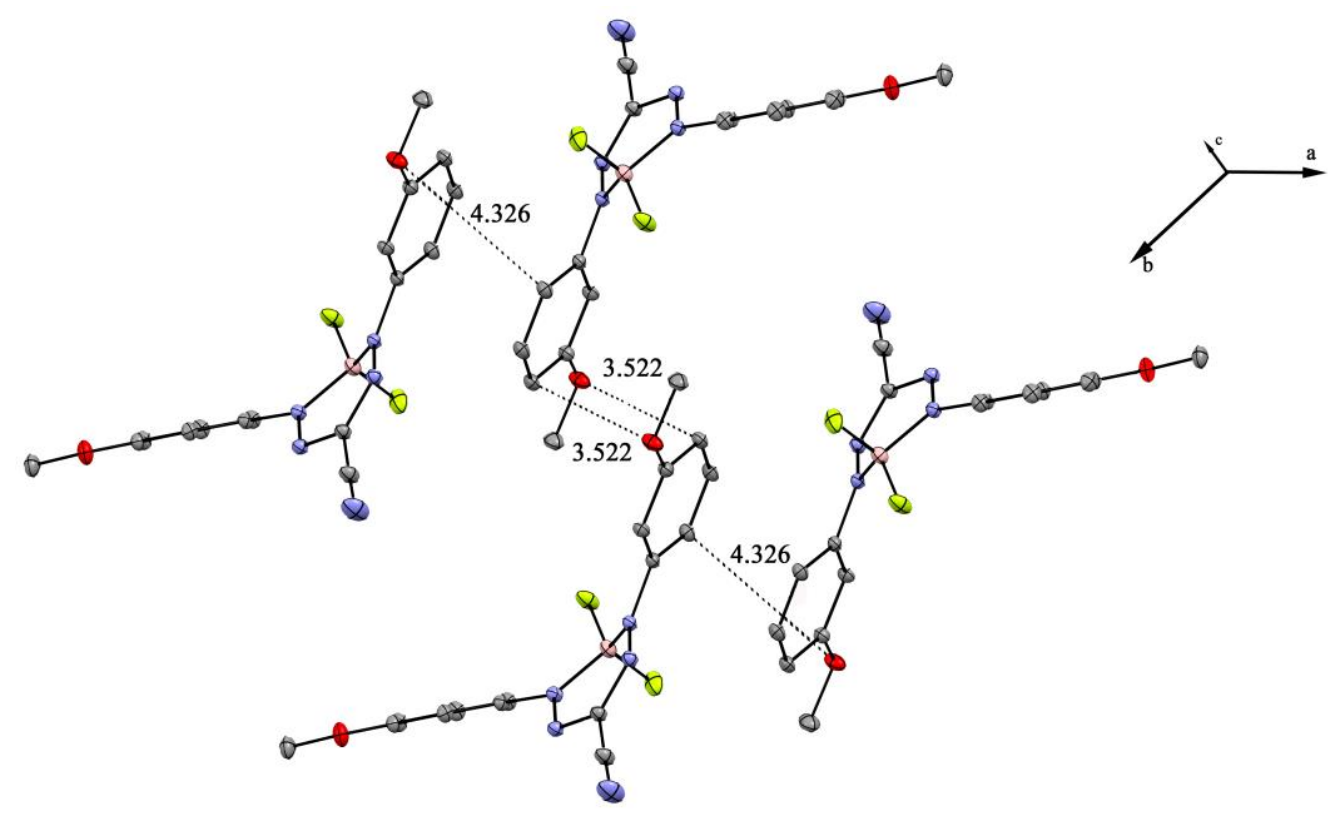

Figure S37. Solid-state packing of 7b. Dashed lines indicate shortest contact points between anisole rings $(\AA)$.

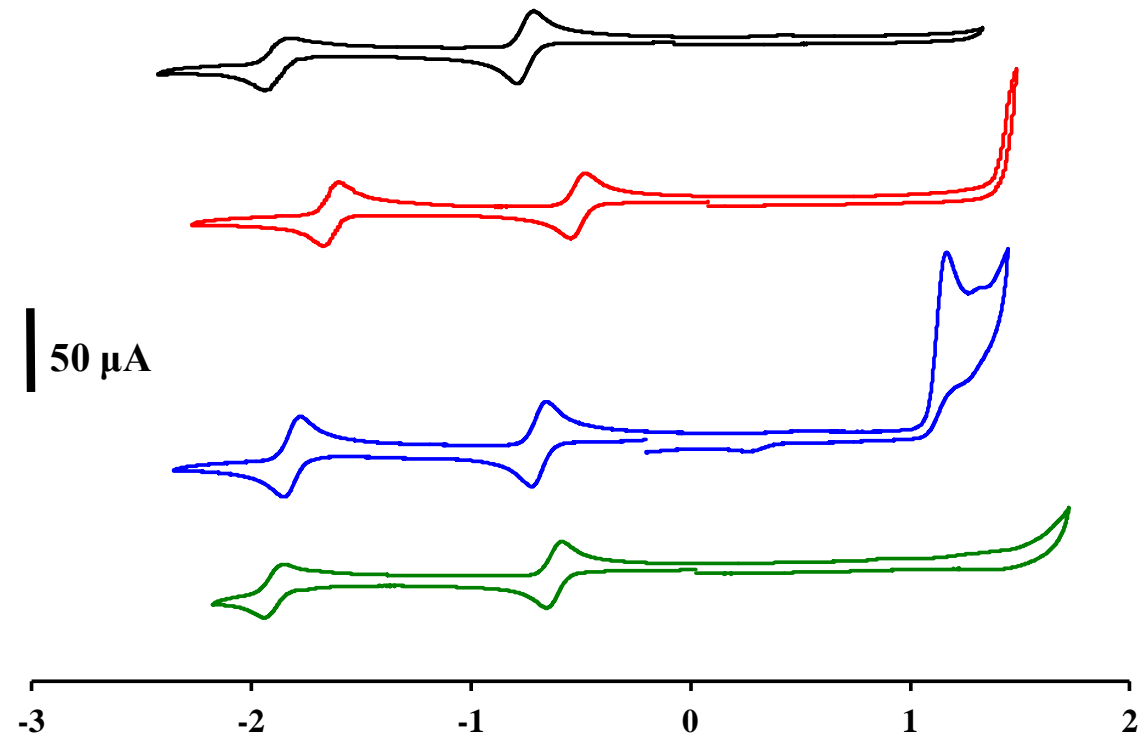

Potential (V vs. Ferrocene / Ferrocenium)

Figure S38. Cyclic voltammograms for $\mathrm{BF}_{2}$ formazanate complexes $7 \mathbf{a}(\mathrm{Ar}=o$-anisole, $\mathrm{R}=$ cyano; black line), $7 \mathbf{b}(\mathrm{Ar}=m$-anisole, $\mathrm{R}=$ cyano; red line $), 7 \mathbf{c}(\mathrm{Ar}=p$-anisole, $\mathrm{R}=$ cyano; blue line), and 7d ( $\mathrm{Ar}=o$-ethylbenzene, $\mathrm{R}=$ cyano; green line) recorded in dry, degassed acetonitrile containing $\sim 1 \mathrm{mM}$ analyte and $0.1 \mathrm{M} n-\mathrm{Bu}_{4} \mathrm{NPF}_{6}$ at a scan rate of $100 \mathrm{mV} \mathrm{s}^{-1}$. 

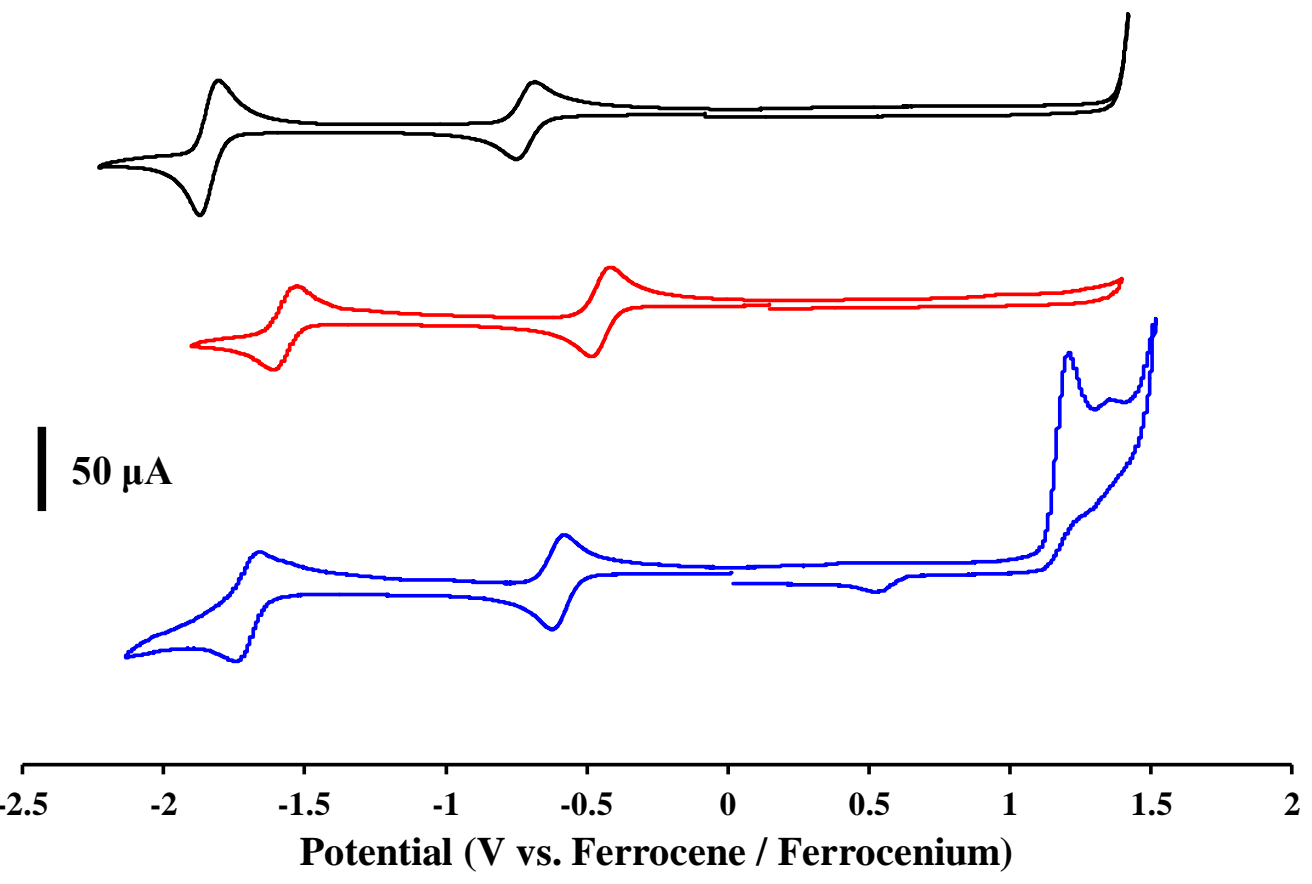

Figure S39. Cyclic voltammograms for $\mathrm{BF}_{2}$ formazanate complexes $8 \mathbf{a}(\mathrm{Ar}=o$-anisole, $\mathrm{R}=$ nitro; black line), $\mathbf{8 b}(\mathrm{Ar}=m$-anisole, $\mathrm{R}=$ nitro; red line $)$, and $\mathbf{8 c}(\mathrm{Ar}=p$-anisole, $\mathrm{R}=$ nitro; blue line) recorded in dry, degassed acetonitrile containing $\sim 1 \mathrm{mM}$ analyte and $0.1 \mathrm{M} n-\mathrm{Bu}_{4} \mathrm{NPF}_{6}$ at a scan rate of $100 \mathrm{mV} \mathrm{s}^{-1}$.

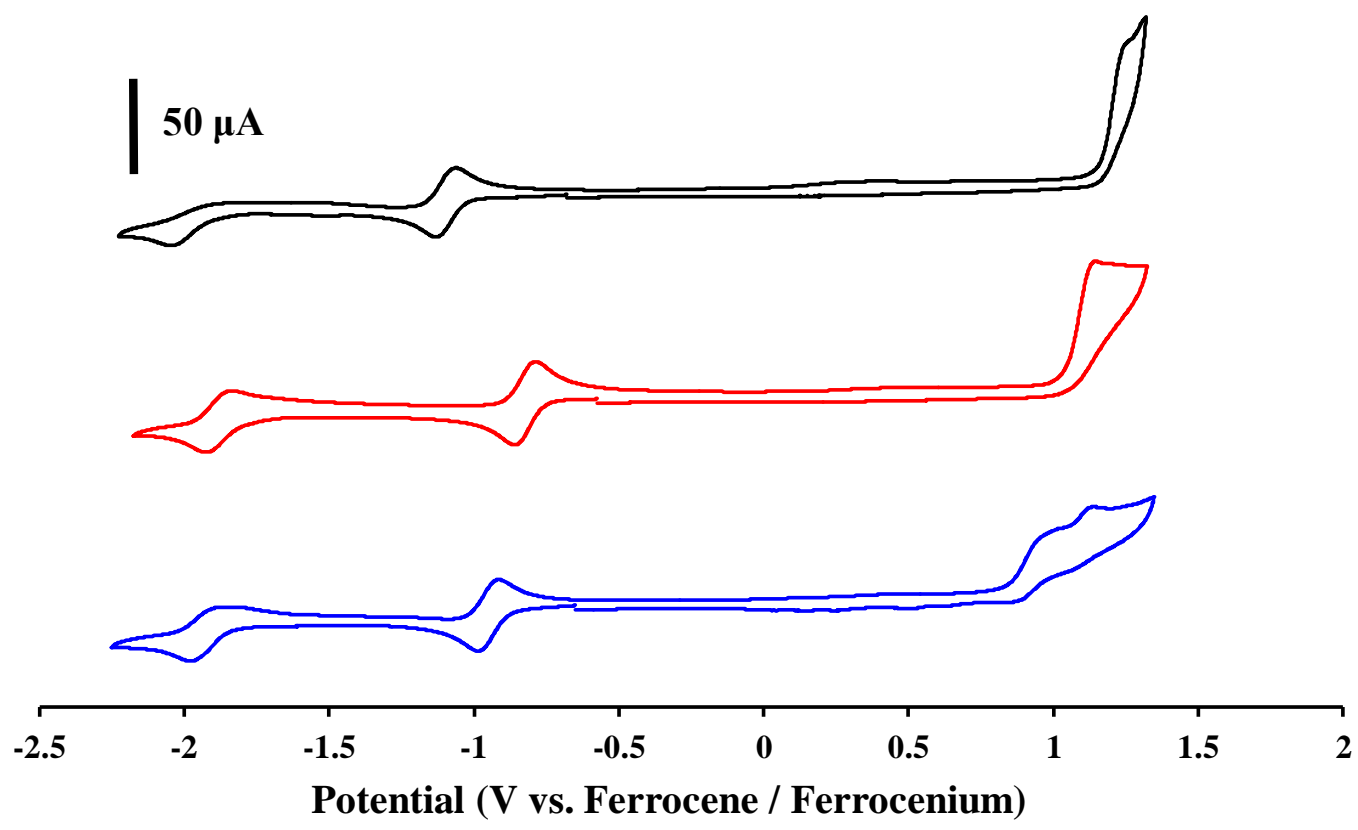

Figure S40. Cyclic voltammograms for $\mathrm{BF}_{2}$ formazanate complexes $9 \mathbf{a}(\mathrm{Ar}=o$-anisole, $\mathrm{R}=$ phenyl; black line), 9b $(\mathrm{Ar}=m$-anisole, $\mathrm{R}=$ phenyl; red line $)$, and 9c $(\mathrm{Ar}=p$-anisole, $\mathrm{R}=$ phenyl; blue line) recorded in dry, degassed acetonitrile containing $\sim 1 \mathrm{mM}$ analyte and $0.1 \mathrm{M}$ $n-\mathrm{Bu}_{4} \mathrm{NPF}_{6}$ at a scan rate of $100 \mathrm{mV} \mathrm{s}{ }^{-1}$. 


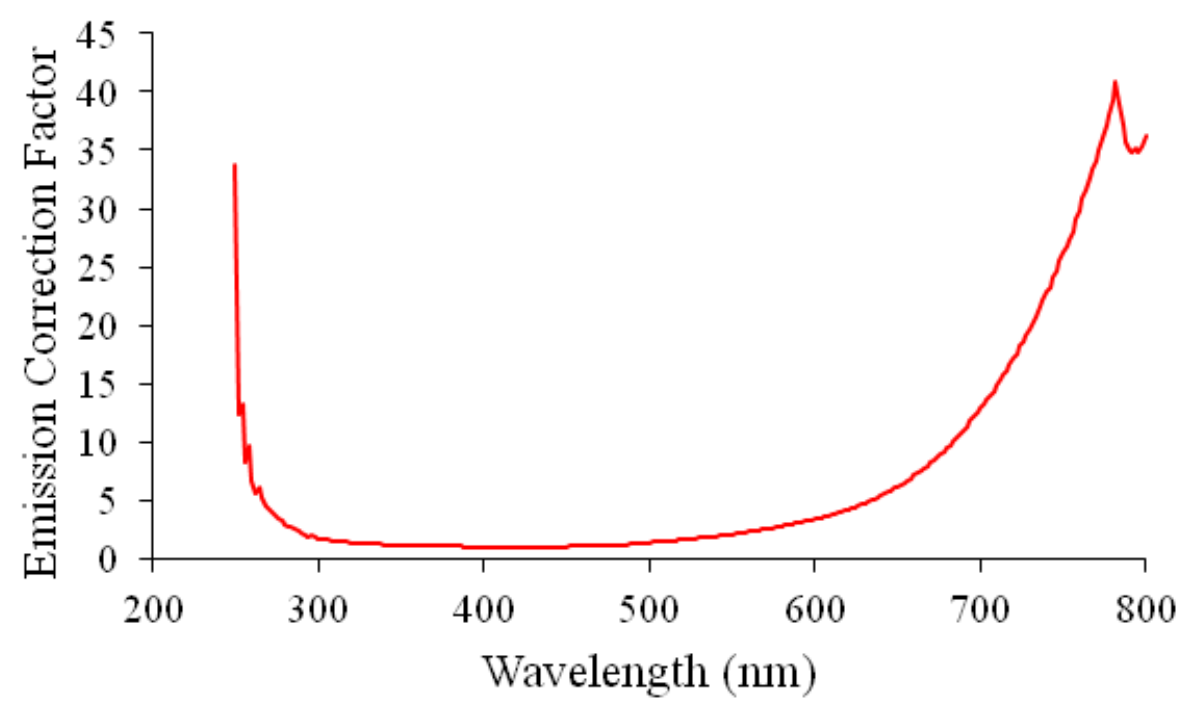

Figure S41. Wavelength-dependent emission correction provided by Photon Technology International.
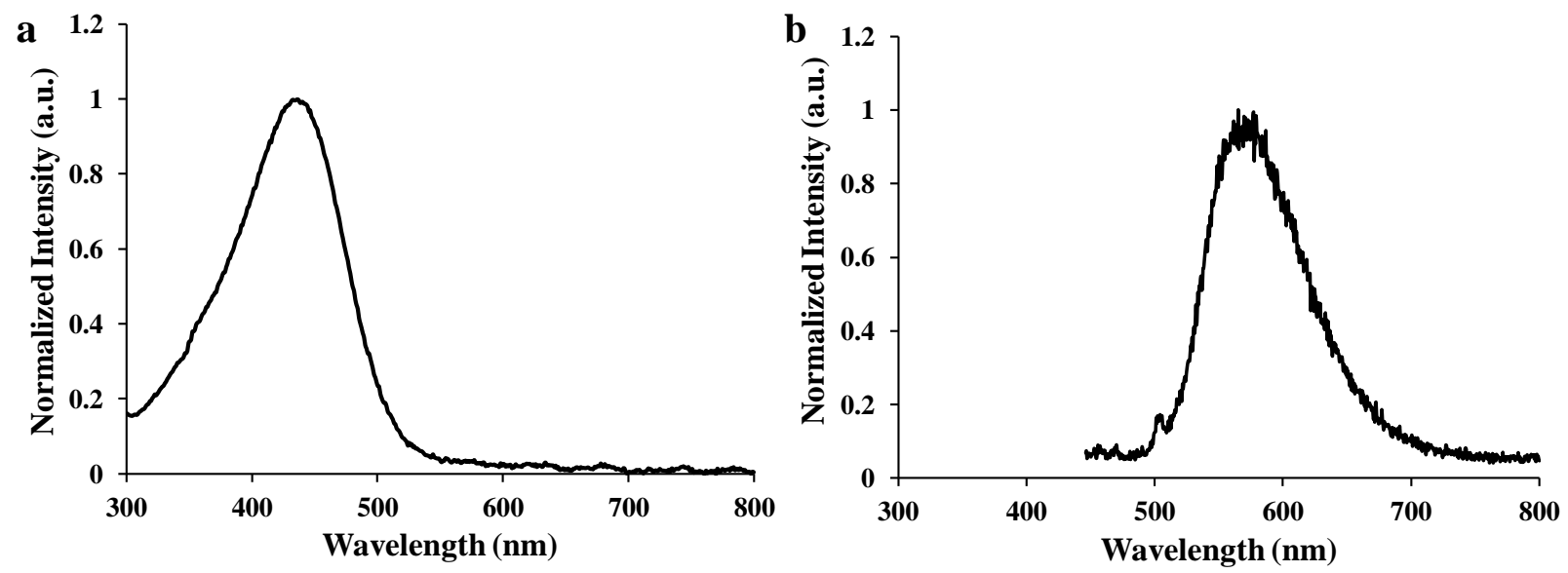

Figure S42. UV-vis absorption spectra (a) and emission spectra (b) for $\mathrm{BF}_{2}$ formazanate complexes 7d $(\mathrm{Ar}=o$-ethylbenzene, $\mathrm{R}=$ cyano) recorded for a degassed $10 \mu \mathrm{M}$ toluene solution. 

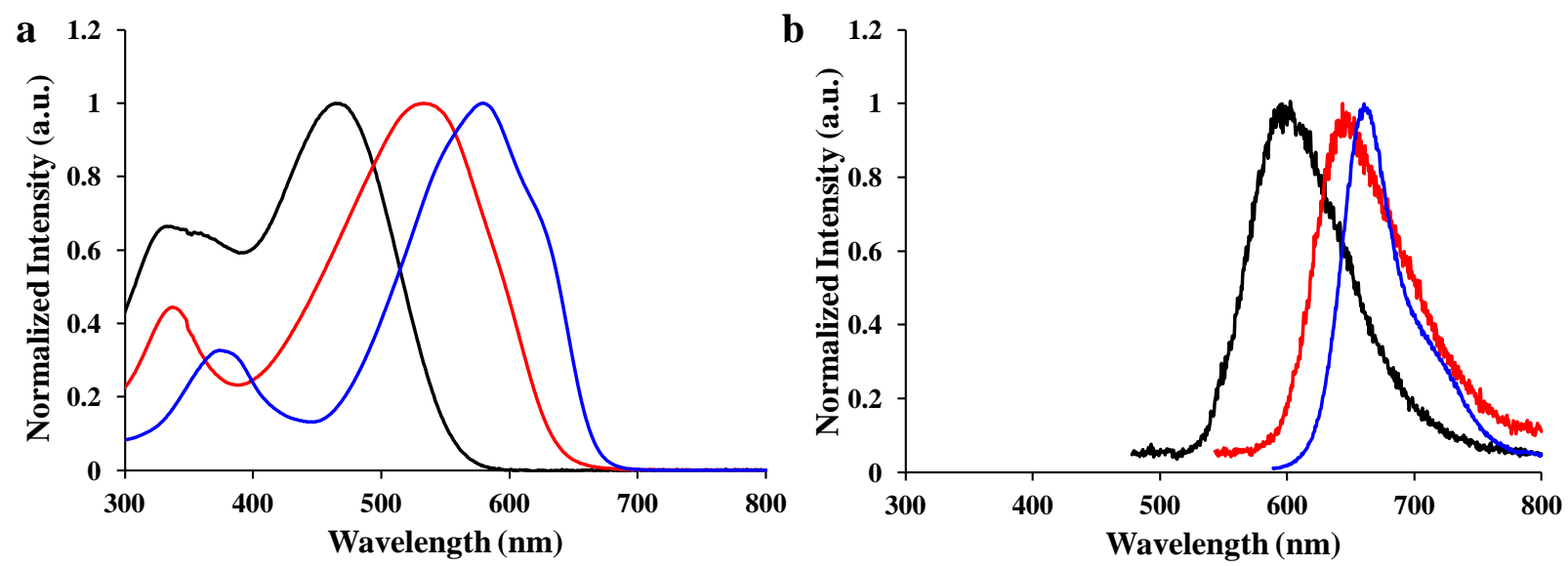

Figure S43. UV-vis absorption spectra (a) and emission spectra (b) for $\mathrm{BF}_{2}$ formazanate complexes 8a $(\mathrm{Ar}=o$-anisole, $\mathrm{R}=$ nitro; black line $), \mathbf{8 b}(\mathrm{Ar}=m$-anisole, $\mathrm{R}=$ nitro; red line $)$, and $\mathbf{8 c}(\mathrm{Ar}=p$-anisole, $\mathrm{R}=$ nitro; blue line $)$ recorded for degassed $10 \mu \mathrm{M}$ toluene solutions.
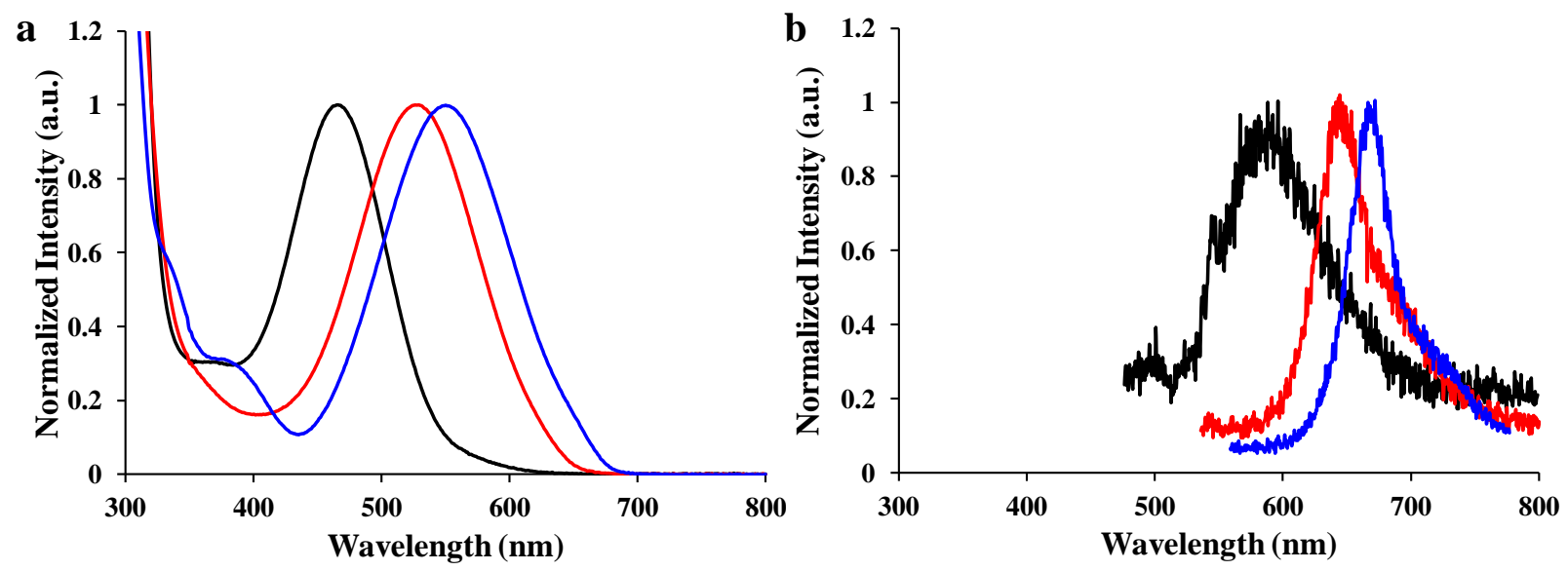

Figure S44. UV-vis absorption spectra (a) and emission spectra (b) for $\mathrm{BF}_{2}$ formazanate complexes 9a (Ar $=o$-anisole, $\mathrm{R}=$ phenyl; black line), 9b $(\mathrm{Ar}=m$-anisole, $\mathrm{R}=$ phenyl; red line $)$, and 9c $(\mathrm{Ar}=p$-anisole, $\mathrm{R}=$ phenyl; blue line $)$ recorded for degassed $10 \mu \mathrm{M}$ toluene solutions. 


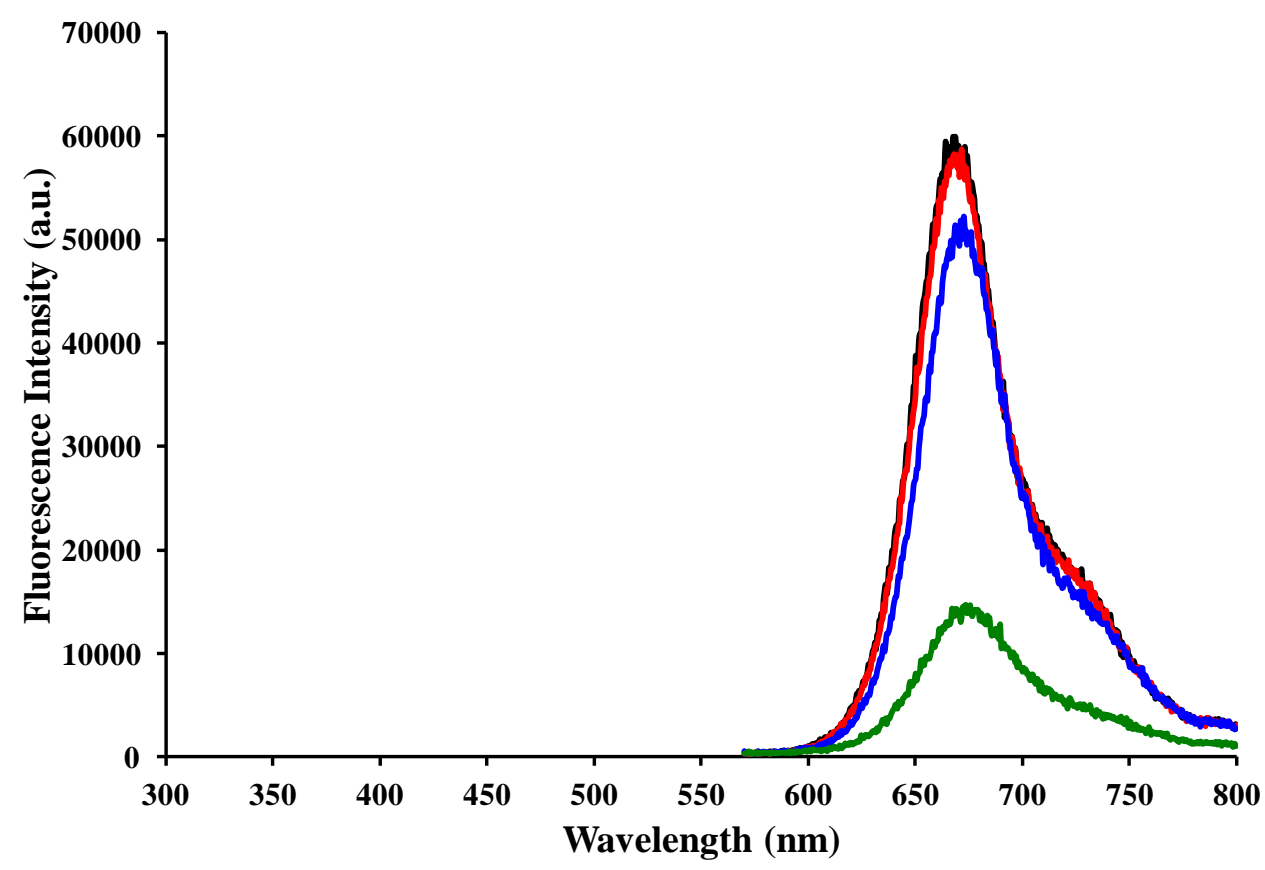

Figure S45. UV-vis emission spectra for $\mathrm{BF}_{2}$ formazanate complexes $9 \mathrm{c}(\mathrm{Ar}=p$-anisole, $\mathrm{R}=$ phenyl) recorded for degassed $10 \mu \mathrm{M}$ tetrahydrofuran/water solutions containing $10 \%$ (black line), $25 \%$ (red line), $50 \%$ (blue line), and $75 \%$ (green line) v/v water. 